\title{
QUALIDADE DE VIDA DE TRABALHADORES DE ENFERMAGEM COM DISTÚRBIOS OSTEOMUSCULARES RELACIONADOS AO TRABALHO
}

Dissertação apresentada ao Programa de Pós-Graduação em Gerenciamento em Enfermagem da Escola de Enfermagem da Universidade de São Paulo para obtenção do título de Mestre em Ciências

Área de concentração: Fundamentos e Práticas de Gerenciamento em Enfermagem e em Saúde

Orientadora:

Prof $^{a}$ Dr $^{a}$ Vanda Elisa Andres Felli 


\section{AUTORIZO A REPRODUÇÃO TOTAL OU PARCIAL DESTE TRABALHO, POR QUALQUER MEIO CONVENCIONAL OU ELETRÔNICO, PARA FINS DE ESTUDO E PESQUISA, DESDE QUE CITADA A FONTE.}

Assinatura:

Data:

\section{Catalogação na Publicação (CIP)}

Biblioteca "Wanda de Aguiar Horta"

Escola de Enfermagem da Universidade de São Paulo

Ratier, Ana Paula Pelegrini

Qualidade de vida de trabalhadores de Enfermagem com distúrbios osteomusculares relacionados ao trabalho / Ana Paula Pelegrini Ratier - São Paulo, 2012.

$$
\text { p. } 105
$$

Dissertação (Mestrado) - Programa de Pós-Graduação da Escola de Enfermagem da Universidade de São Paulo

Orientadora: Prof. ${ }^{\text {a }}$ Dr. ${ }^{\text {a }}$ Vanda Elisa Andres Felli

1. Distúrbios osteomusculares relacionados ao trabalho. 2. Enfermagem. 3. Qualidade de vida. 4. Saúde do trabalhador. I. Título. 
Nome: Ana Paula Pelegrini Ratier

Título: Qualidade de vida de trabalhadores de Enfermagem com distúrbios osteomusculares relacionados ao trabalho

Dissertação apresentada à Escola de Enfermagem da Universidade de São Paulo para obtenção do título de Mestre em Ciências

\section{Aprovado em:}

\section{Banca Examinadora}

Prof.Dr.

Julgamento:

Prof.Dr.

Julgamento:

Prof.Dr.

Julgamento:
Insitutição.

Assinatura:

Insitutição.

Assinatura:

Insitutição.

Assinatura: 


\section{DEDICATÓRIA}

Aos meus pais, meus grandes amores e exemplos de vida, que sempre me incentivaram e tornaram possível meu crescer pessoal e profissional.

À minha avó e aos meus irmãos, por servirem de estímulo para meu caminhar.

Ao Igor, meu anjo na Terra, que ilumina e alegra cada dia de minha vida.

A todos os meus alunos, razão pela qual meu desejo de aprender nunca se apaga. 


\section{AGRADECIMENTOS}

À $\operatorname{Prof}^{a} D^{a}{ }^{a}$ Vanda Elisa Andres Felli, por acreditar no meu potencial e tornar esse estudo possível.

Às Prof ${ }^{a}$ Dr ${ }^{a}$ s Patrícia Campos Pavan Baptista e Valéria Meirelles Carril Elui, pelas valiosas contribuições no Exame de Qualificação.

A todos os membros do Grupo de Estudos sobre Saúde do Trabalhador de Enfermagem, da Escola de Enfermagem da Universidade de São Paulo, pelo auxílio, aprendizado e pela amizade compartilhada.

Às alunas de Terapia Ocupacional do Centro Universitário São Camilo Gabriela Vizzioli e Flávia Sílvia Mendes, por terem colaborado na concretização desse estudo.

À minha equipe de trabalho no HU, em especial, Silmara, Fabiana e Anice, por apoiarem a realização desse sonho.

Aos Departamentos Médico e de Enfermagem do HU e especialmente, aos trabalhadores que aceitaram participar dessa pesquisa.

À minha família.

A Deus.

A todos que direta ou indiretamente contribuíram para a realização desse estudo. 
"O sucesso nasce do querer, da determinação e persistência em se chegar a um objetivo. Mesmo não atingindo o alvo, quem busca e vence obstáculos, no mínimo fará coisas admiráveis". 


\title{
Ratier APP. Qualidade de vida de trabalhadores de Enfermagem com distúrbios osteomusculares relacionados ao trabalho [dissertação]. São Paulo: Escola de Enfermagem, Universidade de São Paulo; 2012.
}

\begin{abstract}
RESUMO
Esse estudo teve como objetivo apreender a qualidade de vida (QV) de trabalhadores de enfermagem acometidos por Distúrbios Osteomusculares Relacionados ao Trabalho (DORT) e construir possíveis estratégias para a melhoria da mesma. Investigamos a QV em trabalhadores de Enfermagem com DORT em membros superiores de um Hospital Universitário. O estudo, de caráter exploratório-descritivo e abordagem qualitativa, foi desenvolvido tendo como população os trabalhadores de enfermagem de um hospital público universitário, constituindo 11 mulheres e dois homens, portadores de DORT em membros superiores, representantes de todas as categorias de enfermagem e de diversas unidades assistenciais. A coleta de dados foi realizada através de entrevista individual e grupo focal. Após aprovação do projeto em Comitê de Ética, a coleta de dados foi iniciada através das entrevistas com os sujeitos eleitos. Foram realizadas, também, cinco sessões de grupo focal, no período de novembro a dezembro de 2011. Os resultados de caracterização mostram que a média de tempo de trabalho nesta instituição é de 19 anos, denotando extensa exposição a cargas fisiológicas; sete trabalhadores realizam, concomitantemente ao trabalho remunerado, afazeres domésticos integralmente e cinco deles parcialmente; as atividades de lazer são apenas ocasionais; a maioria dos sintomas refere-se a quadros dolorosos em ombros, o que acaba prejudicando também a realização de atividades básicas e cotidianas. Após o tratamento dos dados de caracterização, as falas foram submetidas à análise de conteúdo e permitiram apreender quatro categorias: existindo com dor, QV é não ter limitações, meu trabalho influenciando na minha QV e cuidando e sendo cuidado. Na primeira categoria, os relatos revelam a influência da dor na constituição do sujeito, em suas expectativas e sua relação com o quadro emocional. Com relação à qualidade de vida, evidenciamos que esta encontra-se prejudicada pela co-existência de dois aspectos, mencionados na segunda e terceira categorias: dor e consequentes limitações e inadequações na organização e processo de trabalho, sendo mencionados alguns fatores desfavoráveis do cotidiano laboral: excesso de tempo no local de trabalho, inadequação de equipamentos e organização e processos de trabalho inapropriados. Dessa forma, as falas dialogam com as definições de Qualidade de Vida Relacionada à Saúde e Qualidade de Vida no Trabalho, sendo essas indissociáveis do conceito de QV para esses trabalhadores, já que as percepções do valor atribuído à vida estão sob influência da dor e que inadequações no processo de trabalho alteram significativamente a QV. Na última categoria, verificou-se satisfação com o processo grupal, com crescente conscientização e mudanças no cuidado a si. Em especial, foram despertadas ações cruciais para controle de quadros crônicos de DORT: a atenção a si e às combinações de fatores pessoais, físicos, sociais e emocionais. Também foram observados o meio, com seus riscos e benefícios e simples estratégias de saúde, apreendidas e construídas coletivamente. Construiu-se, junto aos trabalhadores, um programa educativo onde foram oferecidas novas perspectivas para amenização de sintomas, bem como modificações comportamentais relacionadas a componentes posturais e ambientais, indo ao encontro de um dos princípios de Promoção da Saúde e abordando um dos pilares da QV para esse grupo. Conclui-se que a QV desses trabalhadores está intimamente relacionada à dor e ao trabalho. Compreendeu-se que há a necessidade de combinação de estratégias mutissetoriais, com responsabilização dos próprios indivíduos e existência de ações coletivas do sistema de saúde e da comunidade.
\end{abstract}

PALAVRAS-CHAVE: Distúrbios Osteomusculares Relacionados ao Trabalho.

Enfermagem. Qualidade de vida. Saúde do trabalhador. 


\title{
Ratier APP. Quality of life in nursing workers with work-related musculoskeletal disorders [thesis]. São Paulo (SP), Brasil: Escola de Enfermagem, Universidade de São Paulo; 2012.
}

\begin{abstract}
This study aimed to capture the quality of life (QoL) of nursing workers affected by Work Related Musculoskeletal Disorders (WMSDs) and build strategies for its improvement. We investigated the QoL of nursing workers with upper limb disorders in a University Hospital. The study is exploratory and descriptive with qualitative approach and was developed with the nursing staff of a public hospital, constituted of 11 women and two men suffering from disorders in the upper limbs, representatives of all categories of nursing and several units. Data collection was conducted through individual interviews and focus groups. After project approval by the Ethics Committee, data collection began with interviews with the chosen subjects. Five focus group sessions were also carried out, from November to December in 2011. The sociodemographic results show that the average working time in this institution is 19 years, indicating extensive exposure to physiological loads; seven workers perform, concurrently with paid work, full housework and five of them partial; leisure activities are only occasional and the majority of symptoms refers to painful shoulders, which ultimately jeopardize the performance of basic activities of daily living. After treatment of the sociodemographic data, the reports were subjected to content analysis which raised four categories: existing with pain, QoL is having no limitations, my job influencing on my QoL and caring and being cared for. In the first category, the reports reveal the influence of pain in the constitution of the subject, their expectations and its relationship with the emotional picture. Regarding the quality of life, we found that it is hampered by the co-existence of two aspects mentioned in the second and third categories: pain and its resulting limitations and inadequacies in the work organization and process, and some unfavorable factors of daily work mentioned were: too much time at work, inappropriate equipment and improper work organization and processes. Thus, the speeches match with the definitions of Quality of Working Life and Health-Related Quality of Life, these being inseparable from the concept of QoL for these workers, since the perceptions of the value attributed to life are under the influence of pain and that inadequacies in the work process significantly alter QoL. In the latter category, there was satisfaction with the group process, with enhanced awareness and changes in their care. In particular, workers were sensitized to crucial ways to control chronic conditions of WMSDs: attention to themselves and to combinations of personal, physical, social and emotional aspects. Increased attention with the environment also happened, with recognition of its risks and benefits and the use of simple health strategies, learned and built collectively. It was built, along with the workers, an educational program where they were offered new prospects for alleviation of symptoms, as well as behavioral changes related to postural and environmental components, meeting one of the principles of Health Promotion and addressing one of the concepts of QoL for this group. In conclusion, QoL of these workers is closely related to pain and work. It was understood that there is a need for multiple combination of strategies, with accountability of the individuals themselves and the existence of collective actions of the health system and community.
\end{abstract}

KEYWORDS: Nursing. Quality of life. Work-related Musculoskeletal Disorders. Worker's Health. 


\section{LISTA DE FIGURAS}

Figura 1 - Distribuição da participação dos sujeitos da pesquisa, segundo a unidade de trabalho, São Paulo - 2011...... 45

Figura 2 - Distribuição dos sujeitos participantes do estudo, segundo as categorias profissionais, São Paulo - 2011

Figura 3 - Atividades de trabalho predominantes realizadas pelos funcionários de Enfermagem, São Paulo - 2011 .... .48

Figura 4 - Diagnósticos predominantes dos funcionários de Enfermagem, São Paulo $-2011$ 49

Figura 5 - Principais sintomas referidos pelos funcionários de Enfermagem, São Paulo - 2011 .50

Figura 6 - Limitações em atividades dos funcionários de Enfermagem, São Paulo 2011 


\section{LISTA DE QUADROS}

Quadro 1 - Categorias elencadas pelos trabalhadores de Enfermagem nos grupos

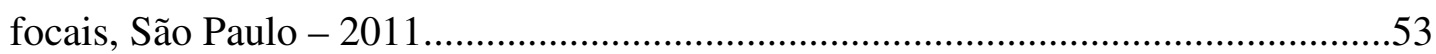




\section{LISTA DE ABREVIATURAS}

A.

Aux. Enf.

Cen.

Cir.

Clin.

Enf.

Med.

Ps

Sínd.

Tec. Enf.
Adulto

Auxiliar de Enfermagem

Centro

Cirúrgica

Clínica

Enfermeiro

Médica

Pronto-socorro

Síndrome

Técnico de Enfermagem 


\section{LISTA DE SIGLAS}

$\begin{array}{ll}\text { AOTA } & \text { American Occupational Therapy Association } \\ \text { CTD } & \text { Cumulative Trauma Disorders } \\ \text { DORT } & \text { Distúrbios Osteomusculares Relacionados ao Trabalho } \\ \text { EE } & \text { Escola de Enfermagem } \\ \text { HU } & \text { Hospital Universitário } \\ \text { LER } & \text { Lesões por Esforços Repetitivos } \\ \text { MSD } & \text { Musculoskeletal Disorders } \\ \text { MMSS } & \text { Membros superiores } \\ \text { OMS } & \text { Organização Mundial da Saúde } \\ \text { OOS } & \text { Occupational Overuse Syndrome } \\ \text { QV } & \text { Qualidade de Vida } \\ \text { QVT } & \text { Qualidade de Vida no Trabalho } \\ \text { QVRS } & \text { Qualidade de Vida Relacionada à Saúde } \\ \text { RSI } & \text { Repetitive Strain Injury } \\ \text { SF-36 } & \text { Medical Outcomes Study 36 - item Short-Form Health Survey } \\ \text { SF-12 } & \text { Medical Outcomes Study 12 - item Short-Form Health Survey } \\ \text { SSO } & \text { Síndrome de Sobrecarga Ocupacional } \\ \text { TCLE } & \text { Termo de Consentimento Livre e Esclarecido } \\ \text { UBAS } & \text { Unidade Básica de Assistência à Saúde } \\ \text { UTI } & \text { Unidade de Terapia Intensiva } \\ \text { USP } & \text { Universidade de São Paulo } \\ \text { WHO } & \text { World Health Organization } \\ \text { WHOQOL } & \text { World Health Organization Quality of Life }\end{array}$




\section{SUMÁRIO}

Motivações para a realização da pesquisa.................................................14

1 Qualidade de vida dos trabalhadores de Enfermagem com DORT .....16

1.1 Os Distúrbios Osteomusculares Relacionados ao Trabalho........................16

1.2 Os DORT em trabalhadores de Enfermagem............................................20

1.3 Qualidade de vida do pessoal de Enfermagem.............................................24

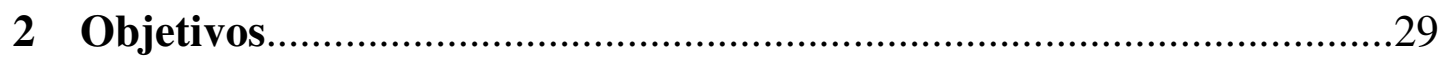

3 Fundamentação teórico-metodológica do estudo....................................30

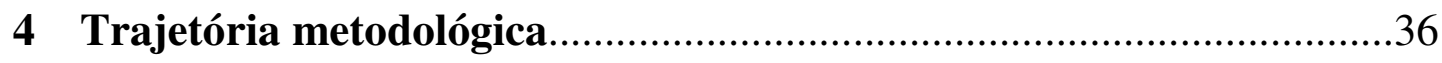

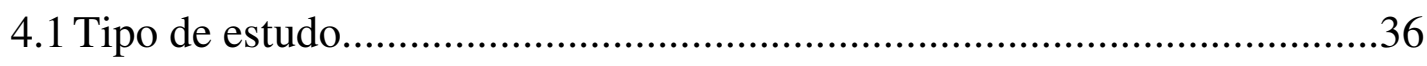

4.2 Cenário de estudo.....................................................................................

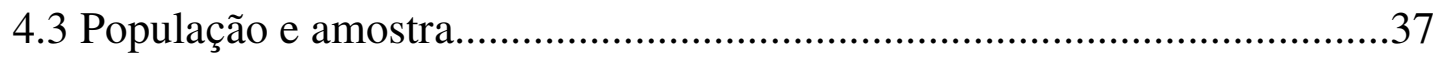

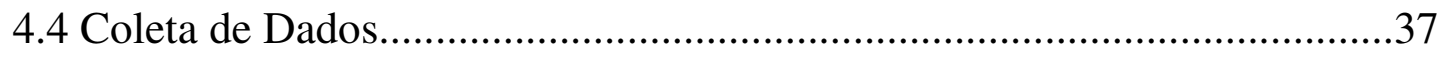

4.4.1 Instrumento de coleta de dados.............................................................38

4.4.2 Procedimentos de coleta de dados........................................................

4.4.3 Procedimentos de análise dos dados.....................................................43

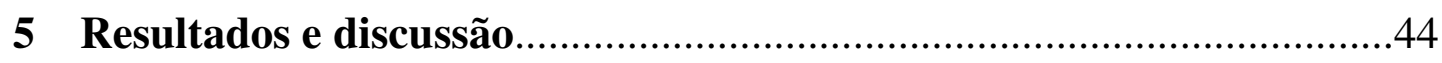

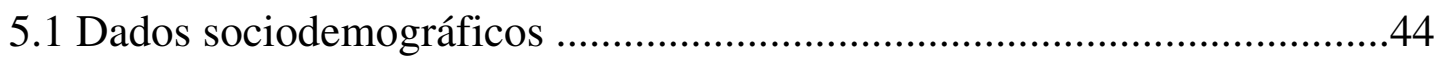

5.2 Dados dos grupos focais........................................................................52

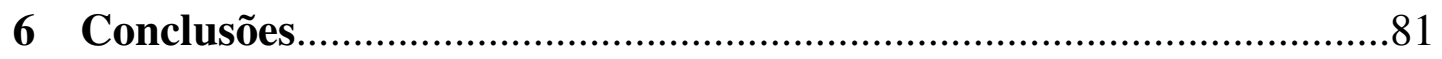

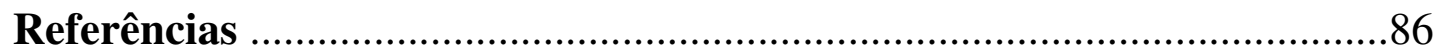

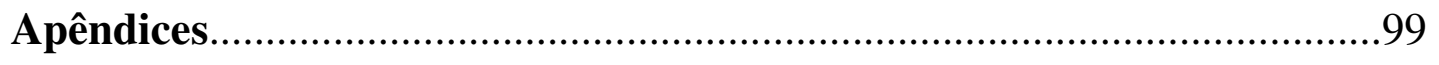

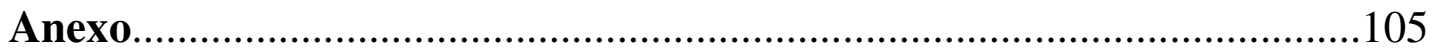




\section{Motivações para a realização da pesquisa}

Desde 2001, sou formada em Terapia Ocupacional e portanto também trabalhadora na área da saúde. Meu histórico profissional é recheado de memórias dos casos mais desafiadores de doenças - que ora me mobilizavam, ora me impediam de modificar o curso de incapacidades e limitações observadas.

Realizei o curso de Especialização em Terapia da Mão, no Hospital das Clínicas da Faculdade de Medicina da Universidade de São Paulo, no ano de 2004, direcionado principalmente à compreensão e tratamento de diagnósticos de patologias traumato-ortopédicas em membros superiores. Notei que, dentre as propostas temáticas oferecidas, havia um certo grupo de pacientes cujos diagnósticos eram de difícil compreensão, sendo igualmente árduas as estratégias de gerenciamento dessas patologias. Esses eram os quadros de Distúrbios Osteomusculares Relacionados ao Trabalho (DORT), na minha opinião, os mais difíceis de serem tratados na Terapia da Mão e considerados, de certa forma, de grandes desafios para as equipes de saúde em geral.

Em 2006, ao ser contratada por um hospital universitário (HU), iniciei minha prática como terapeuta ocupacional, junto a pacientes com os quadros de DORT. Essa contratação, inclusive, partiu de um pedido do Sindicato dos Trabalhadores da Universidade de São Paulo, onde o HU está inserido, que requeria profissionais capacitados para lidar com a crescente população de trabalhadores que adoecia por DORT.

Após alguns meses de prática, percebi nessa população características extremamente peculiares. Por um lado, existia um grupo de trabalhadores acometidos por quadros agudos de DORT, que obtinham rápidas melhoras com o nosso tratamento, mas que vez ou outra, eram reencaminhados devido às recidivas. Quando das reavaliações em retornos, começou a ficar bastante perceptível a influência das atividades de cotidiano do trabalho desses pacientes na piora de seus quadros. 
Por outro lado, percebi que parte dos trabalhadores apresentava quadros crônicos, isto é, estas pessoas já conviviam há meses ou anos com os sintomas dos DORT e suas conseqüências como limitações, perdas ou modificações em papéis, depressão e outros achados infelizmente comuns.

É por essa clientela que me sinto tocada, preocupada em como é existir com um sintoma de difícil resolução e que a acompanha, muitas vezes, até na hora do repouso. Como enfrentar os desafios do cotidiano? Como lidar com a possibilidade de não-cura? Qual o impacto dos DORT na vida desses trabalhadores?

Por um interesse meu e, também, por conveniência da instituição, iniciei atendimentos a essa clientela em grupos. Observei similaridades nas dificuldades e possíveis amenizações. Engajei-me em outros projetos da área nessa mesma instituição, como avaliação ergonômica de setores, e vi-me cada vez mais mergulhada no assunto.

Sempre envolvida com projetos institucionais direcionados aos pacientes com DORT, participei da Comissão DORT do HU, onde convivi com a professora doutora Vanda Elisa Andrés Felli da Escola de Enfermagem da Universidade de São Paulo (EE/USP), também interessada em desenvolver projetos com essa população na Instituição, onde surgiu a oportunidade de realizar essa dissertação. 


\title{
1 A QUALIDADE DE VIDA DOS TRABALHADORES DE ENFERMAGEM COM DORT
}

\author{
1.1 OS DISTÚRBIOS OSTEOMUSCULARES RELACIONADOS AO \\ TRABALHO
}

Os Distúrbios Osteomusculares Relacionados ao Trabalho (DORT) são um tipo específico de doença relacionada ao trabalho que surgiu no Brasil na década de 1980 e, desde o ano 2000, se tornou o maior problema de saúde pública relacionado ao trabalho, constituindo hoje uma epidemia (Brasil, 2001a).

DORT são compreendidos como um conjunto de desordens de origem multifatorial complexa que acomete diversos sistemas e tecidos do organismo (Yeng et al., 2001; Felli et al., 2006). Estão relacionados ao trabalho e caracterizam-se pela ocorrência de vários sintomas, concomitantes ou não, tais como: alterações de sensibilidade, dor, sensação de peso e fadiga, que aparecem de maneira insidiosa, isolados ou difusos, em várias regiões do corpo e cujo curso é diversificado (Brasil, 2003). Com muita frequência, tais sintomas podem levar a diversos graus de incapacidades funcionais importantes (Oliveira, 2006).

Tais afecções podem acometer tendões, sinóvias, músculos, nervos, fáscias e ligamentos, associadas ou isoladas, com ou sem degeneração de tecidos. São causadas por determinantes como movimentos repetitivos, postura, força, velocidade, vibração, direção e ritmo de trabalho, condições antiergonômicas e fatores psicossociais (Miyamoto, 1999), podendo levar a incapacidades temporárias ou permanentes (Brasil, 2003).

A tradição clínica pressupõe que, para correto diagnóstico dos DORT, deve haver uma história clínica e ocupacional sugestiva, com a execução de exames físicos e complementares, incluindo considerações sobre nexo causal (Oliveira, 2006). 
Para o sistema previdenciário brasileiro, além de estarem sujeitos a doenças comuns ao conjunto da população, os trabalhadores podem ser acometidos por “doenças profissionais" e aquelas relacionadas ao trabalho, doenças comuns que têm o espectro de sua etiologia ampliado ou tornado mais complexo pelo trabalho.

São representadas pelas doenças relacionadas ao trabalho as musculoesqueleticas, às quais, por motivos relacionados ao trabalho, somam-se ou multiplicam-se as condições provocadoras ou desencadeadoras desses diagnósticos. Ainda, têm a sua frequência, surgimento e/ou gravidade modificados pelo trabalho (Brasil, 2001a).

As doenças relacionadas ao trabalho tendem a apresentar maior incidência em trabalhadores envolvidos em determinadas atividades, embora não apresentem relação função ocupacional-dependente a priori (Wunsch Filho, 2004). Portanto, o nexo causal será essencialmente de natureza epidemiológica, seja pela observação de alta incidência em determinados grupos ocupacionais ou profissões, seja pela ampliação quantitativa ou qualitativa do espectro de determinantes causais, que podem ser mais bem conhecidos a partir do estudo dos ambientes e das condições de trabalho (Brasil, 2001a).

Embora atualmente a expressão DORT seja mais utilizada em nosso meio podemos encontrar também as siglas: LER (Lesões por Esforços Repetitivos), SSO (Síndrome de Sobrecarga Ocupacional) e seus respectivos correspondentes em inglês: MSD (Musculoskeletal Disorders), CTD (Cumulative Trauma Disorders), RSI (Repetitive Strain Injury) e OOS (Occupational Overuse Syndrome) (Brasil, 2003).

O número de trabalhadores com DORT vêm aumentando progressivamente, o que é explicado pelas transformações no mundo do trabalho. Essas transformações advindas da globalização das sociedades capitalistas impactam nos sistemas produtivos provocando a sua reestruturação e a introdução de novas formas de organização do trabalho, com mudanças nas relações de trabalho (Antunes, 2008). Essas transformações têm exigido do trabalhador maior intensificação do ritmo de trabalho, implicando em maior consumo de força de trabalho, acarretando más condições de vida e trabalho e novas formas de adoecimento, como os DORT.

Dias (2000) refere que as inovações tecnológicas combinadas aos novos métodos gerenciais intensificam o trabalho, em decorrência não só do ritmo, mas 
também das responsabilidades e da complexidade das tarefas, traduzindo-se em uma série de agravos à saúde, como o envelhecimento prematuro, aumento de adoecimento e morte por doenças cardiovasculares e outras doenças crônicodegenerativas, especialmente as osteomusculares relacionadas ao trabalho, além de um conjunto de sintomas na esfera psíquica.

Acredita-se também que tais fatores levem à alta prevalência de DORT, com o objetivo do pronto e rápido oferecimento de produtos com total despreocupação com os limites físicos e psicossociais dos trabalhadores (Brasil, 2003).

De forma a compreender a dinâmica de estabelecimento dos DORT e, por conseguinte, propor estratégias de tratamento eficazes, é importante ressaltar que as lesões musculoesqueléticas relacionadas ao trabalho não são causadas meramente por atividades eventuais, mas sim por processos crônicos influenciados pelas atividades do trabalho (Célia e Alexandre, 2003). Hales e Bernard (1996) afirmam que os fatores de risco para os DORT são classificados em: físicos (manuseio de cargas, esforço físico, posturas inadequadas ou mantidas, movimentos repetitivos), psicoorganizacionais (satisfação no trabalho, suporte social, falta de definição de papéis, pressão no trabalho, avaliação de desempenho baseada em produtividade) e pessoais (gênero, obesidade, tabagismo, histórico de saúde, aspectos socioeconômicos).

Uma variedade de estudos e pesquisas internacionais foi iniciada na década de 1990, denotando a preocupação global crescente com os fatores multifatoriais precipitantes e predisponentes dos DORT (Bongers et al, 2006), bem como com os efeitos na saúde e bem-estar dos trabalhadores (Sluiter, Frings-Dresen, 2008).

Em 2008, nos Estados Unidos da América, as lesões e acidentes não fatais em indústria privada totalizaram 3.696.100, com mais de 1.000.000 de dias de ausência no trabalho, enquanto as lesões do sistema musculoesquelético totalizaram 416.620 ocorrências (United States Department of Labor, 2009).

A taxa de 3,9 acidentados ou com doenças relacionadas ao trabalho a cada 100 mil norte-americanos é bastante diferente da encontrada no Brasil, que é de 42 a cada 100 mil trabalhadores (Brasil, 2010). Estudos norte-americanos e europeus relacionam os DORT não só aos problemas de saúde física, mas também à produtividade e custos associados, com impactos importantes na força de trabalho e limitações de trabalhadores em suas atividades. 
Um estudo canadense informou que, em 1998, o custo estimado para a perda de produção de longo prazo, deficiência causada pelos DORT, foi de US\$ 12,6 bilhões (Health Canada, 2002). Além disso, o estudo revela que eles constituíram os principais problemas de saúde, representando $10,3 \%$ do total da despesa da saúde para aquele país. Settimi et al (1998) refere que o impacto financeiro decorrente das DORT no Brasil pode ser semelhante ao observado no Canadá, embora o seu custo total ainda seja desconhecido.

Somam-se aos custos governamentais também os custos médicos, os custos diretos da empresa contratante (perda de dias de trabalho e treinamento de novos empregados) e os indiretos (alta taxa de absenteísmo, afastamento do trabalho, alta rotatividade de profissionais, baixa autoestima dos funcionários e pobre qualidade do trabalho) (Muggleton, Allen, Chappell, 1999; Dembe, 2002).

Dados estatísticos brasileiros sobre trabalhadores acometidos por tais distúrbios foram atualizados pelo Ministério da Previdência Social até o ano de 2010 (Brasil, 2010). Naquele ano, foram gastos, apenas em benefícios previdenciários, aproximadamente R 294 milhões (Brasil, 2010).

A Previdência Social brasileira considera a concessão de dois tipos de benefícios acidentários: auxílio-doença e auxílio-acidente, aos trabalhadores acometidos por doenças profissionais, doenças relacionadas ao trabalho e acidentes de trabalho.

Em 2010, foram concedidos 340.685 benefícios acidentários para trabalhadores urbanos e rurais nacionais. Desse total, quase $30 \%$ dos benefícios foram concedidos a pessoas com doenças do sistema osteomuscular e do tecido conjuntivo, a classe de diagnósticos de segunda maior expressividade dentre as 22 categorias de diagnósticos usados pela Previdência Social brasileira codificadas com base na Classificação Internacional de Doenças - CID 10 (Brasil, 2010). Apesar do elevado valor dos benefícios pagos, estes não representam a realidade, já que os trabalhadores não notificam essas doenças e buscam cuidados paliativos.

O quadro agudo tradicionalmente apresenta sinais típicos de sobrecarga tendínea/muscular após a realização da atividade profissional, cessando em momentos de repouso e com boa resolutividade quando empregado o tipo certo de tratamento (Brasil, 2001b). Considera-se que intervenções terapêuticas de sucesso 
devem sempre ser realizadas por equipe multidisciplinar e de maneira dinâmica e integrada. As mais preconizadas na fase aguda são: medicamentos anti-inflamatórios, terapias e avaliação e modificação das condições de trabalho (Brasil, 2001b).

Com a progressão do quadro, a piora dos sintomas é expressa por limitações em simples atividades do dia a dia e com intensificação da dor também devido a mudanças de temperatura, execução de movimentos bruscos ou perante alterações emocionais negativas. A cronicidade do quadro, considerada a partir de seis semanas de sintomas, não responde de maneira significativa ao tratamento convencional; a involução observada traz desconfiança na equipe de saúde despreparada e sofrimento e desesperança ao paciente. O indivíduo com dor crônica experimenta intensa experiência subjetiva desagradável, apresentando irritabilidade, mudanças de humor e depressão (Brasil, 2001b).

Dessa forma, os DORT, com sua multifatoriedade causal, configuram-se um importante problema de saúde pública, representando um inquestionável ônus nos indivíduos portadores, em suas famílias, para as instituições de saúde e para a sociedade. Estima-se que, para o ano de 2015, os DORT serão líderes em gastos com saúde e, sequelas temporárias ou permanentes, podem trazer, além do sofrimento físico e emocional do trabalhador, implicações financeiras em esferas privadas e governamentais (Organização Mundial de Saúde - OMS, 2007).

\subsection{OS DORT EM TRABALHADORES DE ENFERMAGEM}

No conjunto dos trabalhadores, os da área da Saúde, especialmente os trabalhadores de Enfermagem, apresentam alta frequência de distúrbios ostemusculares, tanto no contexto internacional como no nacional.

DORT têm se tornado comuns em trabalhadores da área da Saúde e Tinubu et al. (2010) reforçam que a equipe de Enfermagem, como a força de trabalho majoritária em instituições de saúde, está exposta a alto risco de lesões devido, principalmente, às atividades repetitivas de carregar e transferir pacientes e manutenção de posicionamento em posturas antiergonômicas. Salientam, ainda, que a equipe de Enfermagem responde por cerca de $60 \%$ das lesões relacionadas ao 
trabalho. Estudo norte-americano com 1.163 enfermeiros encontrou uma prevalência de sintomas osteomusculares em pescoço, ombros e coluna de $20 \%$, $17 \%$ e $29 \%$, respectivamente (Lipscomb et al, 2004).

Em profissionais atuantes na Nigéria, de 128 entrevistadas, 84,4\% já experimentaram dor musculoesquelética relacionada a atividades ocupacionais, tendo grande representatividade os sintomas na coluna (Tinubu et al., 2010).

Em outro trabalho realizado na Tailândia com enfermeiras de instituição de longa permanência, observou-se que, devido às especificidades de altas demandas físicas exigidas de trabalhadores nesses locais, das 244 enfermeiras entrevistadas, $66 \%$ relataram dorsalgia relacionada ao trabalho (Feng, Chen, Mao, 2007).

No Brasil, país em desenvolvimento, achados de Murofuse e Marziale (2005) sugerem que a maior visibilidade das LER/DORT advém do maior número de pesquisas sobre problemas de saúde em trabalhadores da área da Saúde. Em estudo em rede hospitalar mineira sobre problemas de saúde em trabalhadores de enfermagem, as autoras constataram que, dos 6.070 atendimentos de saúde prestados aos profissionais citados, $35 \%$ deles apresentaram sintomas musculoesqueléticos, sendo $20 \%$ de dores nas costas e 13,7\% de tenossinovites e sinovites (Murofuse, Marziale, 2005).

Leite, Silva e Merighi (2007) complementam que é provável que as características de trabalho de países em desenvolvimento predisponham a piores condições laborais, provavelmente relacionadas à alta demanda de atividades, escassez de recursos humanos, invariabilidade de tarefas, sobrecarga mecânica em determinados segmentos do corpo e intensificação de ritmo, jornada e pressão no ambiente laboral.

Estudos (Felli et al., 2007; Loiola e Felli, 2007; Sápia, Felli, Ciampone, 2009; Araújo, Soares, Henriques, 2009) demonstram que esses trabalhadores apresentam distúrbios musculoesqueléticos pela exposição cotidiana a uma multiplicidade de tarefas repetitivas, intenso ritmo de trabalho e sobrecarga psíquica, implicando em diversos tipos de acometimento e desgastes físicos e mentais. Além dos citados, os distúrbios musculoesqueléticos estão sujeitos às influências culturais, nas quais a cronicidade e incapacidades associadas são condicionadas por constructos sociais (Coggon, 2005). Ainda, segundo Gropelli (2010), as repercussões de doenças osteomusculares podem levar uma parcela de trabalhadores à desistência do 
exercício da profissão, embora a autora afirme que grande parte da equipe de Enfermagem aceite lesões como próprias do ofício e não realize nenhuma intervenção para prevenir lesões relacionadas à ocupação.

O estudo de Sancinetti (2009) com 647 trabalhadores de Enfermagem refere que as doenças relacionadas aos sistemas osteomuscular e conjuntivo representaram $30 \%$ do total. Também relatou que, nesse subgrupo de doenças, os sintomas geraram maior quantidade de dias de ausência no trabalho - 11.948 dias no total. Ainda, evidenciou que os técnicos de Enfermagem apresentaram maior taxa de licenças por doença e os auxiliares de Enfermagem, maior taxa de absenteísmo. Finalmente, dados do estudo constatam que os sintomas do sistema osteomuscular e do tecido conjuntivo representaram maior número de faltas abonadas e aparecem em sexto lugar nas licenças compensadas por folgas. Ressalta-se que no mesmo estudo foi verificado que o percentual mensal de licenças por doença foi inversamente proporcional à taxa de ocupação, sugerindo que os profissionais ausentaram-se por doença posteriormente a períodos de ritmo de trabalho mais intensos (Sancinetti et al., 2009).

A frequência de sintomas musculoesqueléticos entre trabalhadores de enfermagem é grande, independentemente das unidades assistenciais.

Sápia, Felli e Ciampone (2009) apontam a alta prevalência de DORT em funcionários da enfermagem de um ambulatório de um hospital devido, principalmente a grandes exposições a cargas fisiológicas, gerando processos de desgaste em diversos locais do corpo.

Loiola e Felli (2007) relatam incidência de quase 100\% de sintomas musculoesqueléticos em trabalhadores de enfermagem de uma unidade de emergência hospitalar, sendo os principais sintomas em coluna lombar, pés/tornozelos, punhos e mãos. As mesmas autoras apontam que muitos trabalhadores realizam o presenteísmo, acarretando em piora de sintomatologia e levando muitas vezes à cronicidade dos distúrbios.

Martins (2011), em um estudo realizado com 61 trabalhadores de Unidade de Terapia Intensiva de Enfermagem de um HU, evidenciou que, nos últimos 12 meses, todos os trabalhadores apresentaram algum sintoma musculoesquelético, sendo 65,9\% na região de coluna torácica, 63,63\% em região da coluna lombar e 61,3\% nos ombros. Murofuse e Marziale (2005) relatam que sintomas em mãos foram o 
segundo de maior prevalência dentre 255 atendimentos de saúde com indivíduos com queixas musculoesqueléticas. Foram relatados diagnósticos de manifestações como as sinovites e tenossinovites, dedo em gatilho e outras entesopatias, cujo nexo causal pode ser correlacionado com atividades repetitivas e de maior carga física, combinadas com manutenção de posturas inadequadas.

Em outro estudo realizado com 105 funcionários de Enfermagem de um hospital, a prevalência de dor no último ano foi de $93 \%$ e, nos últimos sete dias, foi de $62 \%$, sendo a coluna lombar, ombros e joelhos locais de maiores concentrações de queixas. Ressalta-se que aqueles trabalhadores que cumpriam uma carga horária maior apresentaram maior frequência de dor em punho e mãos (Gurgueira, Alexandre, Corrêa Filho, 2003).

Observamos que, apesar de a maior prevalência de sintomas ocorrer em coluna, alguns estudos já denotam o aparecimento de sintomas musculoesqueléticos em membros superiores (MMSS) (Gurgueira, Alexandre, Corrêa Filho, 2003; Murofuse e Marziale; 2005, Martins, 2011).

Comprometimentos em MMSS dificultam interações relacionais entre o indivíduo e objetos, além de prejudicarem a produção de gestos auxiliares à comunicação e essenciais à afetividade. Assim, o acometimento dos membros superiores significa a interrupção de projetos de vida, com consequências biopssicosociais e econômicas para o sujeito (Ferrigno, 2007).

Os trabalhadores de Enfermagem realizam um trabalho essencialmente manual ao prestarem assistência aos pacientes, exercendo atividades como verificação de sinais vitais, auxílio ou realização de banho, administração de medicações, realização de curativos, digitação ou anotações em prontuários e outras. Dessa forma, utilizam demasiadamente grupos musculares de MMSS nas atividades de assistência, em manuseio de equipamentos e no registro de informações.

$\mathrm{O}$ cuidado em enfermagem submete os trabalhadores a constrangimentos diversos inerentes ao processo de trabalho, com desdobramentos negativos junto à saúde desses profissionais (Magnago et al., 2007).

Portanto, consideramos essencial abordar essa problemática junto aos trabalhadores de Enfermagem, que desempenham suas atividades de cuidado e assistência aos pacientes de instituições de saúde. 


\subsection{QUALIDADE DE VIDA DO PESSOAL DE ENFERMAGEM}

Os DORT acometem um grande número de pessoas que se veem desprovidas de suas capacidades laborais integrais por curto ou longo período, o que por si só acarreta prejuízos na vida pessoal dos indivíduos.

A dificuldade no diagnóstico de DORT, a ineficácia das reabilitações física e funcional total em estágios mais avançados e o consequente impacto dessas lesões trazem grande sofrimento pessoal e profissional, levando muitas vezes a afastamentos ocupacionais prolongados.

Inúmeras são as repercussões psicossociais que a situação de afastamento do trabalho provoca: depressão (Elfering et al., 2008), marginalização social no ambiente de trabalho (Salim, 2003) e doméstico e resignação na condição de doente, além de prejuízos diretos em suas atividades cotidianas e domésticas, sono, dentre outras.

Índices elevados de depressão, ansiedade, somatização e distúrbios de personalidade são mais elevados em pacientes com dor crônica quando comparados à população em geral (Sjostrom et al., 2008).

A entrega total dos trabalhadores às necessidades impostas pelo sistema produtivo gera desdobramentos que vão além do ambiente e das relações de trabalho, trazendo cotidianamente repercussões desfavoráveis nos planos familiar e social, nos quais, por necessidade, privilegia-se a função laboral e deixam-se de lado os cuidados com a própria saúde e bem-estar (Moser, Kehrig, 2006).

Nessa perspectiva, evidenciam-se impactos desses distúrbios na qualidade de vida dessas pessoas.

Recentes pesquisas nacionais e internacionais correlacionam sintomas musculoesqueléticos e diminuição na qualidade de vida dos trabalhadores de diversos ramos de serviço (Martarello, 2005; Cederlund, Iwarsson, Lundborg 2007; Mergener, Kehrig e Traebert, 2008) 
Em um estudo brasileiro realizado com 86 funcionários do serviço de higiene e limpeza de um hospital, foram comparados os escores de qualidade de vida em trabalhadores com e sem sintomas osteomusculares. Naqueles com sintomatologia presente, os escores relacionados à qualidade de vida revelaram diferenças estatisticamente significativas nos domínios capacidade funcional, dor, estado geral de saúde, vitalidade e saúde mental (Martarello, 2005). O mesmo autor destaca fatores referentes ao gênero feminino (devido talvez à dupla/tripla jornada) para o qual a questão do trabalho doméstico, sobrecarga de trabalho e desgaste físico e mental influenciam negativamente a qualidade de vida, já que, além da mulhertrabalhadora, espera-se que esta assuma uma série de outros papéis.

Em 108 trabalhadores industriais europeus que utilizam de maneira repetitiva ferramentas vibratórias, observou-se que, mesmo nos trabalhadores sem sintomas de síndrome de vibração ombro-mão, aproximadamente 35\% destes apresentavam diminuição na qualidade de vida, número que foi de quase $50 \%$ nos trabalhadores já diagnosticados (Cederlund, Iwarsson, Lundborg 2007). Salientamos que as dificuldades nas atividades de vida diária eram significativamente maiores nos trabalhadores com síndrome ombro-mão advinda da vibração.

Mergener, Kehrig e Traebert (2008) sugerem que quadros de dor e desconforto típicos dos DORT ocasionam limitações das tarefas cotidianas que por sua vez, acabam afetando a Qualidade de Vida.

Outros estudos apresentam maior incidência de DORT no sexo feminino e justificam-na por questões hormonais, pela dupla jornada de trabalho, pela falta de preparo muscular para determinadas tarefas e também pelo incremento do número de mulheres no mercado de trabalho (Przysiezny, 2000; Salim, 2003; Ghislene, Merlo, 2005; Leite, Silva, Merighi, 2007).

No entanto, as mulheres ainda têm um papel social diferenciado dos homens, assumindo outras atividades no cuidado do lar, dos filhos e do companheiro.

As queixas relacionadas à qualidade de vida podem piorar ao longo do tempo em severidade, duração e extensão (Sluiter, Frings-Dresen, 2008).

Portanto, acreditamos que, além de tratamentos médico e de reabilitação, há que se ampliar a conduta terapêutica dos trabalhadores com DORT, de forma a abordar integralmente as necessidades de saúde e cujas ações terapêuticas sejam pautadas nas condições de vida dos sujeitos. 
Muitas publicações encontradas em bases de dados da área da Saúde versam a respeito de estudos epidemiológicos que correlacionam qualidade de vida a profissões específicas, relacionadas às áreas de odontologia, enfermagem, ensino, bancária e industrial acometidas por DORT (Michelin, Loureiro, 2000; Murofuse, Marziale, 2001; Mergener, Kehrig, Traebert, 2006; Santos, Mendes, Araujo, 2009).

No entanto, na área de Enfermagem, ainda existe uma carência de estudos que denotem a relação entre o acometimento por DORT e o impacto na qualidade de vida dos trabalhadores de Enfermagem na sua especificidade, e, sobretudo, propostas de tratamento adequadas e resolutivas. Ainda, os estudos existentes sobre o tema são, na vasta maioria das vezes, quantitativos. Abordam a avaliação da qualidade de vida, realizada através de questionários padronizados, como o Medical Outcomes Study 36 - item Short-Form Health Survey (SF-36) e sua versão reduzida, o Medical Outcomes Studies 12 - item Short-Form (SF-12), o instrumento de avaliação de qualidade de vida da OMS, o WHOQOL-100 e sua versão reduzida, o WHOQOL-bref, e, também, a validação de instrumentos de qualidade de vida: Work Related Activities, Work Role Functioning Questionnaire e Spitzer Quality of Life Index (Franco, Barros, Nogueira-Martins, 2005; Oler et al., 2005; Talhaferro, Barboza, Domingos, 2006; Paschoa, Zanei, Whitaker, 2007; Fogaça, Carvalho, Nogueira-Martins, 2010).

Estudos realizados com esses instrumentos evidenciam alguns aspectos da QV dos trabalhadores de Enfermagem com DORT.

Estudo com 33 funcionários da Enfermagem de um centro cirúrgico, com duplo vínculo de trabalho, avaliados através do SF-36, apresentou pelo menos um sujeito com referência de prejuízo da saúde, justificado, em todos, pelo valor mínimo menor que 50. Exceto pelo prejuízo em aspectos sociais, também encabeçaram a lista de domínios mais prejudicados dor e vitalidade (Oler et al., 2005).

Em outro estudo realizado com 46 funcionários da Enfermagem de central de esterilização de materiais, a análise de dados provenientes do questionário SF-36 evidenciou prejuízos estatisticamente significativos na qualidade de vida em três domínios: dor, vitalidade e aspectos físicos (Talhaferro, Barboza, Domingos, 2006)

Outro recente estudo realizado com 37 médicos e 20 enfermeiros intensivistas avaliados pelo WHOQOL-100, revela que a qualidade de vida de ambas as categorias profissionais que trabalham em unidades de terapia intensiva pediátrica e 
neonatal, em todas as suas dimensões (física, psicológica, nível de independência, meio ambiente, relações sociais e aspectos espirituais/religiosidade/crenças pessoais) está comprometida (Fogaça, Carvalho, Nogueira-Martins, 2010). Achados semelhantes e com o uso do WHOQOL-100 foram evidenciados em outro estudo realizado somente com enfermeiros intensivistas (Paschoa, Zanei, Whitaker, 2007).

Os resultados dos estudos quantitativos não satisfazem a expectativa de conhecer, na perspectiva do trabalhador, certos aspectos, como esperança, coragem, resiliência e flexibilidade, por exemplo, características que são percebidas na prática profissional cotidiana, em que se nota que os pacientes tentam achar estratégias de superação das dificuldades impostas por suas condições.

Se por um lado os dados permitem compor grupos diferentes de trabalho e cultura, Ong et al. (2006) referem que o uso de questionários fechados nem sempre contempla todas as informações para o entendimento mais amplo da problemática, ou porque o sujeito da pesquisa não compreende o significado das perguntas ou devido às divergências nas intenções do pesquisador e em como o entrevistado interpreta o que lhe é questionado. Acredita-se ainda que questionários não expressam a totalidade da experiência pessoal vivida pelos trabalhadores portadores de DORT.

Em contrapartida, estudo realizado na perspectiva crítica (Felli, Tronchin, 2010) evidencia os problemas de saúde e um perfil patológico que expressa a QV relacionada ao trabalho de enfermagem. No entanto, nessa abordagem, não se alcança a percepção do trabalhador, ou seja, o significado que ele atribui a sua QV, mesmo os DORT compondo o perfil patológico desses trabalhadores.

A percepção da "qualidade de vida" através da perspectiva dos trabalhadores acometidos por DORT pode auxiliar na criação de programas de intervenção mais adequados e melhor instrumentalizar esses trabalhadores acerca de seus distúrbios.

Dessa forma, interessa-nos compreender os significados de qualidade de vida de profissionais de enfermagem com DORT e construir, com estes, um espaço para elaboração de sua doença e limitações advindas, criando coletivamente alternativas para lidar com seu sofrimento emocional e físico, expectativas, modificações e motivações.

O conhecimento sobre o impacto dos DORT na qualidade de vida dos trabalhadores ainda não é consolidado. Interessa-nos saber em que grau os sintomas 
musculoesqueléticos influenciam a qualidade de vida desses trabalhadores e, em especial, explorar um vazio importante na literatura que diz respeito àqueles acometidos por quadros em membros superiores. Também, ainda não foram aprofundadas as implicações dos DORT na vida diária dos trabalhadores e na sua qualidade de vida.

Nesse contexto, questionamo-nos: os trabalhadores de Enfermagem com DORT apresentam perdas em sua qualidade de vida? Que alternativas e estratégias para melhoria da qualidade de vida podem ser elaboradas e propostas?

Buscando a resposta a essas questões, motivamo-nos a realizar este estudo. 


\section{OBJETIVOS}

- Apreender a qualidade de vida de trabalhadores de Enfermagem acometidos por DORT;

- Construir possíveis estratégias para a melhoria da QV. 


\section{FUNDAMENTAÇÃO TEÓRICO-METODOLÓGICA DO ESTUDO}

Em muitos estudos, os autores concordam que é necessário transcender a questão apenas física dos DORT e buscar compreender a subjetividade do trabalhador que sofre desse(s) distúrbio(s), que vê implicados em suas vivências pessoais e sociais, seus sintomas, déficits, incapacidades e sua qualidade de vida (Pinheiro, Tróccoli, Carvalho, 2002; Ghislene, Merlo, 2005).

Qualidade de vida e padrão de vida foram objetos de estudo, inicialmente de cientistas sociais, filósofos e políticos (Fleck et al., 1999) e são um tema constantemente abordado tanto em contextos informais quanto em pesquisas científicas.

O interesse pelo tema QV no campo da saúde brasileira ganhou atenção inicialmente com pacientes oncológicos, nos quais se verificou a necessidade de se prolongar a vida com qualidade (Fleck et al., 1999). Acredita-se que o interesse crescente pelo tema se deve a possibilidades de utilizar as informações sobre QV como indicadores importantes do processo de saúde e doença e como avaliação de práticas propostas pelos serviços de saúde (Morris, Perez, McNoe, 1998).

Acreditamos que QV seja um resultado de percepções individuais que são variáveis, nas quais devemos considerar parâmetros objetivos e subjetivos para sua correta definição e correlacioná-los à experiência de vida de cada pessoa.

$\mathrm{Na}$ tentativa de se definir melhor esse conceito bastante subjetivo, Farquhar (1995) pontua que os estudos na área surgiram com as primeiras definições globais de QV na década de 1980 e com o passar dos anos, caminhou-se para a valorização de seus componentes específicos, como o interesse crescente em verificar habilidades funcionais e itens relacionados à saúde física; remontam a esse período o aparecimento dos inúmeros instrumentos para avaliação de QV (Vido, Fernandes, 2007).

Atualmente, a QV pode ser definida como um conceito genérico e multifatorial, como bem ilustrado pela World Health Organization (WHO, 1995): “a percepção do indivíduo em sua posição na vida, no contexto da cultura e sistema de 
valores nos quais ele vive e em relação aos seus objetivos, expectativas, padrões e preocupações".

Na mesma perspectiva da WHO, Minayo, Hartz e Buss (2000) afirmam que o sentido de qualidade de vida aproxima-se de graus de satisfação em várias esferas da vida, levando em consideração o que aquela sociedade considera como padrão de conforto e bem-estar. Os mesmos autores afirmam que qualidade de vida "tem no conceito de promoção da saúde seu foco mais relevante", fato este que também pode ser correlacionado às falas de pacientes, que atribuem à saúde grande significado.

Ao considerarmos os aspectos relativos aos agravos da saúde e os impactos destes na QV, surge também a definição de Qualidade de Vida Relacionada à Saúde (QVRS), proposto por Guianchello (1996) e Auquier, Simeoni e Mendizabal (1997), no qual os últimos a definem "como o valor atribuído à vida, ponderado pelas deteriorações funcionais; as percepções e condições sociais que são induzidas pela doença, agravos, tratamentos; e a organização política e econômica do sistema assistencial".

Agregado às múltiplas possíveis definições de QV, encontramos o desenvolvimento de mais um conceito - a Qualidade de Vida no Trabalho (QVT). Esse conceito, originário da Inglaterra está intimamente relacionado com a compreensão da dinâmica de trabalho - considerando indicadores econômicos, sociais e individuais - e como esta afeta o bem-estar do trabalhador e seu desempenho e satisfação (Schmidt, Dantas, Marziale, 2008).

A maioria dos autores considera que a saúde é apenas um dos domínios da qualidade de vida, observando que a "presença de doença ou anormalidade" pode trazer consequências desastrosas que alteram consideravelmente a qualidade de vida como um todo, e é nesse campo que diversos profissionais de saúde podem propor estratégias para efetiva melhoria, mesmo que a uma parcela dela. Reconhecemos e ressaltamos que muitos outros âmbitos da qualidade de vida são de responsabilidade do governo, do empregador e até mesmo do próprio indivíduo.

A avaliação da qualidade de vida tem sido tema de recentes pesquisas no Brasil, sendo a enfermagem, a categoria profissional com maior número de investigações, nestes últimos anos (Fogaça, Carvalho, Nogueira-Martins, 2010). Os mesmos autores afirmam, entretanto, que em alguns trabalhos são comparadas a qualidade de vida de profissionais da enfermagem e outras condições sistêmicas ou 
profissões, o que de certa forma dificulta a obtenção de dados fidedignos, que efetivamente analisam a qualidade de vida nesse tipo específico de trabalho com suas particularidades.

$\mathrm{Na}$ perspectiva quantitativa, têm sido hegemonicamente usados os questionários. Dos instrumentos encontrados, tem grande expressão o WHOQOL100 e sua versão resumida, o WHOQOL- bref, instrumentos desenvolvidos pela World Health Organization - WHO (1995). O primeiro consta de 100 questões que avaliam seis domínios: físico, psicológico, independência, relações sociais, meio ambiente e espiritualidade/crenças pessoais. Outros de uso bastante comum: EuroQol-5 dimensions (EQ-5D) (Sauni et al., 2010), SF-36 (Poole, Mason, 2005) e sua versão reduzida SF-12 (McPhee, Lipscomb, 2009).

Esses instrumentos quantificam agravos à qualidade de vida e atestam em quais domínios ela está prejudicada, mas fica claro que a complexidade do tema ainda não consegue ser abordada de forma singular, impossibilitando profundidade nas respostas e sua consequente compreensão.

Em se tratando de uma condição incapacitante física e socialmente, faz-se extremamente necessária a elucidação de aspectos da qualidade de vida de pessoas com DORT de forma a facilitar a composição de estratégias multidisciplinares para auxiliar no melhor enfrentamento dessa condição. Nessa perspectiva, a pesquisa qualitativa pode servir de mecanismo de geração de ideias para o pesquisador, permitindo que ao observar e escutar a população objetivo, ele fique munido de estratégias para criação de propostas adequadas para melhoria da QV dos sujeitos.

Vários profissionais da equipe de saúde podem atuar no diagnóstico, prevenção e tratamento dos DORT; no entanto, é o terapeuta ocupacional que, junto a esta população, pode auxiliar na promoção de um estilo de vida mais saudável através do uso de atividades, técnicas específicas, orientações ergonômicas, treino de atividades de vida diária e de trabalho, criação de espaços para expressão e elaboração de sentimentos e construção de estratégias para amenização dos sofrimentos físicos e psíquicos (Guterres, Barfknecht, 2005; American Occupational Therapy Association - AOTA, 2008).

Nesta perspectiva, a Terapia Ocupacional compreende que a saúde é fortemente influenciada pelas escolhas e controle individuais que o indivíduo detém sobre suas ocupações cotidianas, bem como pelo ambiente sociocultural que o cerca; 
pode então oferecer soluções aos desafios associados à intensa mudança de rotina e de hábitos concomitantes aos DORT (AOTA, 2008).

De maneira a seguir as diretrizes propostas pela Política Nacional de Promoção da Saúde (Brasil, 2004), uma intervenção grupal de Terapia Ocupacional auxilia na promoção da qualidade de vida e redução da vulnerabilidade de riscos à saúde, onde se almeja a construção de estratégias individuais e coletivas de experiências saudáveis perante as limitações impostas pela doença.

Os conceitos derivados da Política Nacional de Saúde vêm sofrendo constantes modificações ao longo dos anos, mas a base da política brasileira e de muitos outros documentos internacionais, que versam sobre o assunto, estrutura-se em dois pilares principais: um deles consiste em projetos relacionados a transformações comportamentais nos indivíduos e tem como metas principais alterar hábitos cujo controle é próprio daquele que o realiza; em outro pilar, temos a responsabilização do coletivo e das diversas esferas estatais pela alteração de políticas públicas capazes de criar condições favoráveis à saúde (Brasil, 2004).

Concebida há cerca de 30 anos no Canadá, a compreensão da Promoção da Saúde busca uma concepção generalista do processo de saúde-doença e de seus determinantes, onde almeja combinar múltiplos saberes e estratégias - Estado, sociedade e indivíduos - para a criação de políticas eficientes para ausência de enfermidades e consequente bem-estar (WHO,1986).

São enumeradas três estratégias fundamentais para o alcance da Promoção da Saúde (WHO,1986). Uma delas é a capacitação da sociedade, para que conheçam e controlem fatores que determinam a saúde. Entre a esfera individual e as responsabilidades de esferas governamentais, o pessoal da saúde deve responder pela mediação dos interesses individuais e coletivos, assegurando que sejam realizadas propostas factíveis e necessárias. Por último, também é uma estratégia dessa política a Defesa da Saúde, que engloba as estratégias de vários setores em níveis diversos, incorporando conhecimentos de áreas correlatas à saúde, mas que agregadas, possibilitem garantir que fatores culturais, sociais, econômicos e ambientais promovam a saúde.

Muito mais presente na atualidade é a ideia de que a promoção da saúde não é de ordem exclusiva do indivíduo, mas também engloba a criação de legislações favoráveis e ambientes saudáveis, o empoderamento da sociedade para escolha das 
propostas mais cabíveis e a reorientação do sistema de saúde, cuja ação deve ser desprendida da unicidade do tratamento de doenças para a compreensão do processo saúde-doença e sua prevenção, bem como para o cultivo de qualidade de vida e bemestar (Buss, 2000).

No referencial da Promoção da Saúde, muitos autores advogam o uso de grupos de diversas modalidades junto a portadores de DORT (Merlo, Jacques, Hoefel, 2001; Hoefel et al., 2004), como modalidades de avaliação e intervenção. Os resultados indicam maior conscientização dos trabalhadores a respeito dos nexos causais, podendo então verificar-se uma diminuição na culpabilização individual comum aos acometidos por DORT, bem como são fomentadas alternativas para minimização de sofrimento psíquico e físico advindos dos sintomas osteomusculares.

As discussões e reflexões oriundas nos grupos são, normalmente, associadas a técnicas clássicas de Fisioterapia e que acabam transcendendo a abordagem clínica dos DORT, pois a elaboração mútua de estratégias de enfrentamento para limitações físicas, psíquicas e sociais implica em um maior empoderamento dos sujeitos (Merlo, Jacques, Hoefel, 2001).

Hoefel et al. (2004) afirmam que alguns autores advogam sobre o uso de grupos terapêuticos em populações com DORT, nas quais benefícios possíveis seriam a elaboração de estratégias de enfrentamento de sintomas, sequelas e limitações físicas e sociais. Em consonância, está a Política Nacional de Promoção da Saúde (Brasil, 2004), que prima, dentre outros enfoques, pela ampliação do escopo dos sujeitos em escolhas saudáveis, ampliando o repertório de estratégias destes para melhoria de sua qualidade de vida. Ainda, complementam que estar em um grupo potencializa a construção de ações sociais individuais e coletivas.

Dentre as modalidades de intervenções grupais, acreditamos que, para os trabalhadores acometidos, a técnica de grupo focal seja apropriada. Isto porque dentro de seus preceitos, é possível intensificar a disponibilidade de informações a respeito de um determinado fenômeno, no qual reflexões e percepções individuais (verticalidade) vão se modificando à medida que se constrói o saber coletivo (horizontalidade).

Os grupos focais podem ser definidos como técnicas de pesquisa nas quais os sujeitos discutem vários aspectos de um tópico específico. Sua forma de operacionalização advém da teoria de Grupo Operativo de Pichon-Rivière (1991). 
Para o autor, os componentes do grupo possuem um objetivo em comum e com as experiências grupais, todos aprendem novas condutas (Pichon-Rivière, 1991).

Dessa forma, trabalhar em grupos focais implica realizar uma pesquisa-ação, auxiliando portadores de DORT a compreender de maneira mais aprofundada a problemática que vivenciam cotidianamente e criar maneiras de resolução ou amenização de seus quadros (Dall'Agnol, Trench, 1999). Concordando com essa afirmação, Borges e Santos (2005) relatam que desde a década de 1980, os grupos focais têm sido amplamente utilizados para o desenvolvimento de pesquisas e educação em saúde.

Como técnica de coleta de dados, os grupos focais caracterizam-se por uma estratégia de entrevista coletiva, com duração média de uma hora e meia a duas horas. A amostra deve ser intencional e a quantidade de pessoas pode variar de 8 a 10 participantes, mas um número em que o melhor aproveitamento possível poderia acontecer seria de 5 a 7 membros (Debus, 1997).

As sessões dos grupos focais devem ser precedidas por uma sessão inicial, na qual todos os integrantes foram apresentados e em que foram detalhadamente explicitados os objetivos e regras do grupo, incluindo aqui compromissos éticos.

Deve acontecer em um ambiente privado, com pouco ruído, cômodo, neutro, localizado em um local de fácil acesso e, se possível, com um observador que não intimide o grupo. $\mathrm{O}$ observador estará atento à discussão e às expressões não verbais, que guardam grande significado do discurso. Depois o grupo, observador e moderador reunir-se-ão para recapitular o que foi dito e visto e terão a oportunidade de esclarecer e cristalizar o significado do que foi dito (Dall'Agnol, Trench, 1999).

Dadas as potencialidades do grupo focal, inclusive a que permite intervir com os trabalhadores, optamos por essa técnica para alcançar os objetivos do estudo. 


\section{TRAJETÓRIA METODOLÓGICA}

\subsection{TIPO DE ESTUDO}

Trata-se de um estudo de caráter exploratório-descritivo de abordagem qualitativa, no qual pretendemos compreender os significados de qualidade de vida para trabalhadores com DORT crônicos e construir estratégias coletivas, na tentativa de maximizar a qualidade de vida destes, seguindo os princípios da Terapia Ocupacional e da Promoção da Saúde.

A pesquisa qualitativa busca desvendar o universo de significações, atitudes e valores de determinada população, compreendendo o ser humano e suas interrelações com o mundo (Minayo, 2008). Além disso, a pesquisa qualitativa pressupõe uma profundidade de compreensão nas respostas, em que, muito mais do que observar comportamentos e atitudes, a natureza da investigação qualitativa trata dos aspectos emocionais e contextuais da resposta humana, onde não há pretensão pura e única de obter respostas, mas sim, interpretá-las.

\subsection{CENÁRIO DE ESTUDO}

O cenário de nosso estudo foi o ambulatório de Fisioterapia e Terapia Ocupacional do HU-USP, localizado na zona oeste da cidade de São Paulo.

Esse hospital é um órgão de uma universidade, está ligado ao Sistema Único de Saúde e caracteriza-se por ser um hospital geral, de atenção secundária, que possui 247 leitos para internação e realiza atendimentos emergenciais e ambulatoriais diários em diversas especialidades, direcionados à população do Butantã e à comunidade USP. 


\subsection{POPULAÇÃO E AMOSTRA}

A população do estudo foi constituída pelos trabalhadores de Enfermagem do hospital campo de estudo, que somam 644, sendo 184 enfermeiros, 327 técnicos de Enfermagem e 133 auxiliares de Enfermagem. A amostra intencional foi constituída pelo grupo de 13 sujeitos que atenderam aos seguintes critérios de inclusão:

- ser portador de DORT que envolva sintomatologia de membros superiores;

- ter no mínimo 6 semanas de sintomas.

Os critérios de exclusão:

- ter outros diagnósticos ortopédicos, neurológicos e/ou reumatológicos em MMSS;

- ter realizado tratamento de terapia ocupacional;

- ter realizado mudança de função.

A seleção de participantes com sintomatologia de MMSS deve-se à já mencionada escassez em trabalhos que avaliem e proponham intervenções junto a esses trabalhadores, enfatizado pelo fato de estudos anteriormente citados reforçarem estatísticas significativas de incidência de DORT também nos MMSS. Até o presente momento, temos uma minoria de estudos na área de Enfermagem que dialogam sobre DORT nessa região do corpo, já que a grande maioria que é acometida por esses distúrbios nessa categoria profissional apresenta sintomatologia em coluna.

O critério de escolha por sujeitos com mais de seis semanas de quadro levanos a estudar aqueles acometidos de maneira crônica, que são, tradicionalmente, pacientes cujos tratamentos vigentes têm pouca ou nenhuma resolutividade.

\subsection{COLETA DE DADOS}




\subsubsection{Instrumento de coleta de dados}

Para a coleta de dados, utilizaremos um formulário como instrumento, dividido em duas partes (APÊNDICE 1).

A primeira parte é constituída por questões fechadas e pretende traçar um perfil dos sujeitos da pesquisa. Essa parte será aplicada em entrevista individual para assegurar ao participante confidencialidade e vínculo inicial com a pesquisadora.

A segunda parte do instrumento, composta por questões semiestruturadas norteadoras, será aplicada através de entrevista coletiva. Essa parte busca captar a percepção dos trabalhadores acerca de sua qualidade de vida e fatores que interferem nesta, bem como coletar informações úteis, que possam direcionar a terapeuta ocupacional para elaboração de propostas adequadas no grupo terapêutico. A entrevista coletiva será aplicada durante os grupos focais, modalidade escolhida para a coleta dos dados, com o intuito de promover reflexões e elucidar opiniões contrárias e favoráveis à natureza do tema e fomentar ideias mais ricas relacionadas à temática proposta.

\subsubsection{Procedimentos de coleta de dados}

Os sujeitos da pesquisa foram convidados a participar do grupo focal, direcionado por um terapeuta ocupacional. Foram considerados aptos a participar aqueles que, além de se encaixarem nos critérios de inclusão do estudo, forem encaminhados pelos médicos da instituição em questão ou funcionários que procurem o serviço de Terapia Ocupacional espontaneamente.

Foram realizados grupos focais do tipo semi-estruturado utilizando como técnica de interrogatório o método de moderação não diretivo, no qual são utilizadas perguntas abertas que permitem ao participante expressar seus sentimentos verdadeiros e reduzem ao mínimo a influência do moderador. A quantidade de grupos obedeceu à satisfação do pesquisador quanto às respostas às inquietudes relacionadas ao tema. 
Durante as sessões aconteceram, concomitantemente, discussões acerca da qualidade de vida, bem como a construção de alternativas para maximização desta, direcionadas por terapeuta e trabalhadores.

O tratamento proposto foi de cunho educativo-terapêutico, em que, em cada sessão de grupo, os pacientes e terapeuta construíram estratégias para melhoria da qualidade de vida, especialmente através de princípios da Terapia Ocupacional relacionados à Promoção da Saúde, como: conhecimento de seus diagnósticos e prováveis nexos causais, técnicas de analgesia, relaxamento e massagem, exercícios de alongamento e fortalecimento, orientações sobre proteção articular nas atividades diárias, uso correto de grupos musculares, simulação de atividades de trabalho, orientações ergonômicas, reflexões e discussões acerca do cotidiano de trabalho, doméstico, de lazer e elaboração de soluções coletivas para desafios individuais cotidianos.

Após análise criteriosa dos questionários individuais, optamos por estruturar os grupos da seguinte maneira:

- Primeiro encontro: apresentações, justificativas da busca pelo grupo e discussão sobre qualidade de vida. Definições de DORT e prováveis nexos causais (Brasil, 2001b).

- Segundo encontro: discussão sobre estratégias mais utilizadas para analgesia. Orientações sobre termoterapia e massagens (Michlovitz, Nolan, 2005).

- Terceiro encontro: discussão sobre estratégias mais utilizadas para lazer. Orientações sobre atividades de lazer e prática de relaxamento (Mitchell, 1977, Marcelino, 1990).

- Quarto encontro: discussão sobre estratégias mais utilizadas para ergonomia. Orientações sobre posturas e posicionamentos adequados no diaa-dia (Alexandre, Rogante, 2000).

- Quinto encontro: reforço de orientações, discussão sobre objetivos alcançados e sugestões de continuidade. Escolha de intervenção realizada pelos pacientes.

Após aprovação do projeto pelo Comitê de Ética e Pesquisa, iniciamos a busca pelos sujeitos da pesquisa. 
Para a eleição dos sujeitos, o projeto foi apresentado de maneira detalhada ao Departamento de Enfermagem da instituição campo da pesquisa e foi, posteriormente, levado à reunião de chefias de Enfermagem para a divulgação e captação dos funcionários interessados. Na ocasião da divulgação, foram oferecidos dois períodos diferenciados para a realização de dois grupos: um às terças-feiras, das 14h15 às 15h30 (Grupo 1), e outro às quartas-feiras, das 17h00 às 18h15 (Grupo 2).

Além da divulgação por parte das chefias, foi disponibilizada em cada setor uma planilha com a descrição do projeto, composta também de um local para inscrição dos sujeitos interessados, onde deveriam ser anotados nome, telefone e email (APÊNDICE 2). Tal planilha permaneceu nos setores por um período de 15 dias, e durante esse período a pesquisadora passou em diversos setores da instituição para reforçar junto às enfermeiras de plantão a divulgação aos trabalhadores.

A implementação de estratégias diversas para a divulgação do projeto se fez bastante produtiva, uma vez que alguns setores desconheciam o projeto quando da visita da pesquisadora; não obstante, com a presença da pesquisadora no local de trabalho dos prováveis sujeitos-alvo, foram também tiradas dúvidas quanto à possibilidade de faltas e detalhes sobre as abordagens do grupo.

Em uma terceira fase, após um período de 15 dias, as planilhas foram retiradas de cada setor e a pesquisadora compareceu novamente à Diretoria de Enfermagem para comunicar o encerramento das inscrições e iniciar contatos com os funcionários. Nesse momento, foi feito contato com todos os interessados.

Houve interesse de 45 funcionários na participação dos grupos focais, 33 dos quais preferiam o Grupo 1 e os 12 restantes, o Grupo 2. Quanto à representatividade das unidades assistenciais, a maioria dos trabalhadores que procurou o grupo era do Pronto-socorro Adulto (14 sujeitos), seguida do setor da UTI adulto (10 sujeitos) e, ainda, sete trabalhadores do Centro Cirúrgico e seis da Clínica Médica. Em menor número, houve também a procura de trabalhadores do Centro Obstétrico, Alojamento Conjunto, Enfermaria Pediátrica, Berçário, Unidades Básicas de Assistência à Saúde (UBAS) e Clínica Cirúrgica.

Nota-se que, em setores de atendimento a adultos que necessitam de um maior nível de assistência, se concentrou um número maior de sujeitos, o que provavelmente denota uma maior sobrecarga nesses locais. 
Para a delimitação dos sujeitos dos grupos, a pesquisadora entrou em contato telefônico com os trabalhadores e inicialmente expressou os objetivos da pesquisa e os critérios de inclusão e exclusão. Já nessa terceira fase, muitos trabalhadores foram excluídos do projeto por não apresentarem diagnóstico médico e alguns por terem outros quadros de doenças ortopédicas, sendo, em sua maioria, artroses em MMSS.

Dado o grande interesse de participação de trabalhadores de enfermagem de determinados setores, além da obediência aos critérios de elegibilidade da pesquisa, realizamos a escolha aleatória (por sorteio) de trabalhadores por proporcionalidade de interessados em cada local. Isso porque entendemos ser importante essa representatividade maior de parcelas de trabalhadores de determinados setores, inferindo que talvez, nos locais de maior interesse, pudéssemos encontrar um maior número de pessoas em acometimento crônico ou ambientes de sobrecarga de trabalho. Dessa forma, decidimos contemplar em maior quantidade trabalhadores do Pronto-socorro Adulto, da UTI Adulto, do Centro Cirúrgico e da Clínica Médica e todos os representantes dos demais setores.

Após essa terceira triagem, selecionamos 14 interessados para o Grupo 1 e seis interessados para o Grupo 2. Devido ao risco de não continuidade do Grupo 2 e ao risco reduzido do número de participantes, bem como da posterior desistência de alguns integrantes, por fatores alheios à realização do trabalho, optamos então por realizar dois grupos com início às $14 \mathrm{~h} 15$, um às terças-feiras e outro às quartasfeiras. Dos seis interessados do Grupo 2, três concordaram em participar do novo horário proposto, em razão do número amostral maior e consequente segurança para coleta de dados. Todos os participantes inelegíveis ou excluídos por falta de quorum foram avisados quanto à impossibilidade de participação nesta pesquisa (na ausência de conversa com o próprio interessado, foi passado à chefia deste o antes mencionado).

Concluída a quarta fase de triagem dos participantes, obtivemos: 9 trabalhadores para o Grupo 1 e 7 trabalhadores para o grupo 2, números amostrais adequados para a realização de grupos focais segundo Debus (1977). Prosseguiu-se para o agendamento das entrevistas individuais, marcadas segundo a disponibilidade dos participantes.

Durante a coleta de dados, ocorreram três desistências; a nova composição dos grupos 1 e 2 foi, respectivamente, sete e seis pessoas. Os grupos tiveram a 
duração média de uma hora e quinze minutos e foram realizadas cinco sessões, todas gravadas em áudio-gravador e posteriormente transcritas para análise.

Nos itens a seguir, sintetizamos, cronologicamente, as etapas de triagem dos participantes que viriam a fazer parte dos grupos:

- $1^{\text {a }}$ fase: reunião com chefia de Enfermagem do HU: divulgação do projeto na Reunião de Chefias

- $\quad 2^{\mathrm{a}}$ fase: disponibilização de planilhas para inscrição: visitas aos setores para reforço dos objetivos dos grupos e critérios de inclusão e exclusão

- $\quad 3^{\text {a }}$ fase: contato telefônico com todos os inscritos: delimitação de amostra quanto aos critérios de elegibilidade, retirada das planilhas e aviso às chefias sobre o término das inscrições

- $4^{\mathrm{a}}$ fase: contato telefônico com os sorteados e os excluídos do projeto: explicação de impossibilidade de participação

- $5^{\mathrm{a}}$ fase: realocação de funcionários sorteados em grupos 1 e 2: agendamento para entrevista individual e preenchimento do Termo de Consentimento Livre e Esclarecido.

Cada grupo contou com um observador (discentes do curso de Terapia Ocupacional), que foi treinado pela pesquisadora a respeito de suas responsabilidades e atuação nos referidos grupos. As discentes foram apresentadas como observadores e, após cada finalização de sessão, pesquisador e observador discutiam sobre os fatos relevantes ocorridos e realizavam apontamentos para a sessão, conteúdo este que foi também agregado à análise de dados.

Os trabalhadores que, voluntariamente, aceitaram participar do estudo, assinaram o Termo de Consentimento Livre e Esclarecido - TCLE (APÊNDICE 3). Além disso, o estudo obedeceu às diretrizes e normas regulamentadoras de pesquisas envolvendo seres humanos, conforme a Resolução 196/96, do Conselho Nacional de Saúde. Para assegurar a confidencialidade dos dados obtidos, os trabalhadores, quando citados no texto, foram identificados pela letra $S$, de sujeitos, recebendo as siglas S1, S2 e assim por diante.

Entre novembro e dezembro de 2011, foram realizadas cinco sessões de aproximadamente uma hora e quinze minutos, que ocorreram uma vez por semana, totalizando um mês e uma semana. Houve um primeiro encontro individual com cada sujeito e, a partir do término da primeira parte, foi iniciado o grupo focal. Os 
encontros aconteceram na sala de Terapia Ocupacional do referido $\mathrm{HU}$ e foram conduzidos por uma terapeuta ocupacional e pesquisadora deste projeto.

\subsubsection{Procedimentos de análise dos dados}

Os dados sociodemográficos foram analisados com vista à caracterização da população e também, para fornecer dados úteis para a elaboração de estratégias grupais.

Os depoimentos obtidos foram transcritos e submetidos à técnica de análise temática, uma das modalidades da análise de conteúdo (Minayo, 2008), agrupando as informações por temas que se constituíram nas categorias de análise. Foram realizadas três etapas para sistematização dos dados (falas dos sujeitos participantes): pré-análise, exploração do material, tratamento dos resultados obtidos e interpretação. Na pré-análise foi realizada a leitura flutuante das falas obtidas e elaborado o corpo do texto. Nessa fase, iniciamos a categorização de temas de maior emergência para orientar a análise do material, procedendo então para a fase de exploração do material. Nesta, buscamos recortar o texto em unidades de registro relevantes, para posterior agregação dos dados. A última etapa consistiu em correlacionar as unidades de registro e realizar inferências e interpretações, bem como discutir com outros autores o tema. 


\section{RESULTADOS E DISCUSSÃO}

Os resultados foram analisados em dois momentos: caracterização dos sujeitos segundo dados sociodemográficos e análise de conteúdo dos dados dos grupos focais.

\subsection{DADOS SOCIODEMOGRÁFICOS}

Os dados de caracterização, além de fornecerem informações sobre a população em recorte, foram também utilizados para o preparo das orientações passadas a cada sessão.

Obtivemos um total de 13 sujeitos que finalizaram toda a pesquisa, sendo dois homens e 11 mulheres. Mais da metade dos sujeitos da pesquisa são casados e 11 deles possuem filhos, possuindo em sua maioria um ou três filhos.

A grande maioria demora, em média, de 20 a 40 minutos para se deslocar em um dos trajetos de ida ou volta ao trabalho. O carro é o meio de transporte com utilização majoritária, por dez sujeitos do grupo estudado.

O cotidiano extraprofissional é vivenciado, em mais da metade deles, pela realização integral de atividades de cuidado com a casa e filhos. Cinco deles realizam atividades mais leves e apenas uma pessoa não realiza afazeres domésticos.

Observamos nos sujeitos da pesquisa ausência de pessoas com menos de 30 anos de idade, sendo a idade média 46 anos (de 31 a 60 anos de idade).

Devido ao espaço físico, e para o melhor andamento das propostas, os grupos focais foram divididos em dois, cuja distribuição encontra-se na figura a seguir: 

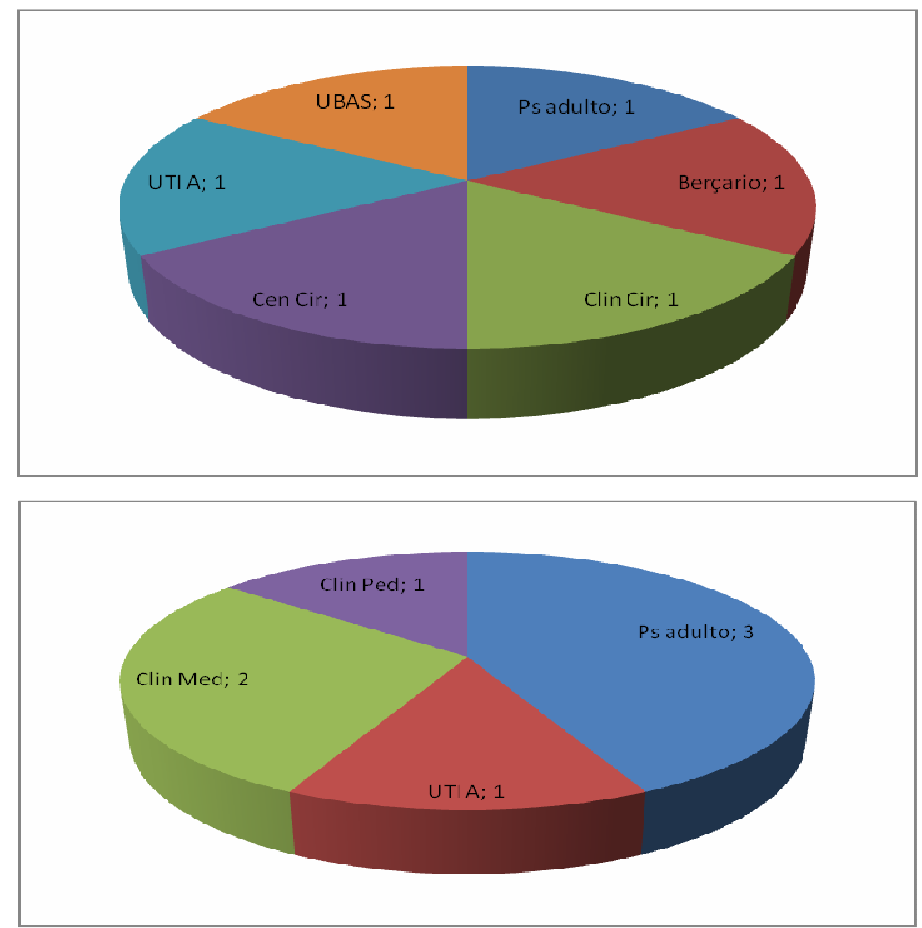

Figura 1 - Distribuição da participação dos sujeitos da pesquisa, segundo a unidade de trabalho, São Paulo - 2011

Como já mencionado, houve uma grande procura de funcionários de alguns setores específicos, especialmente aqueles que lidam com pacientes internados.

Nos anos 1990, Marziale e Carvalho (1998) já discutiam que setores de internação de pacientes, que requerem maior assistência da enfermagem, trazem maiores índices de absenteísmo, tendo em sua maioria correlações com afecções no sistema osteomuscular. Tal fator pode influenciar negativamente na qualidade de cuidado de enfermagem prestada ao paciente. Para essas autoras, os motivos de ausências por licenças saúde podem estar associados ao processo de trabalho e dos equipamentos utilizados.

De maneira semelhante, autoras afirmam que, dentre as ausências previstas e não previstas em setores de internação do mesmo $\mathrm{HU}$ onde realizamos nossa pesquisa, a licença médica foi o fator de maior ocorrência de ausências não previstas nas categorias de auxiliar e técnico de Enfermagem em todas as Unidades de Internação, indicando uma provável correlação com sobrecarga de trabalho (Fugulin, Gaidzinski, Kurcgant, 2003). 
Exercer suas funções em setores de internação parece também decrescer a capacidade para o trabalho, o que pode indicar comprometimento do sistema osteomuscular. Um estudo que objetivou avaliar a capacidade para o trabalho em funcionários da Enfermagem de diversos setores constatou que trabalhadores do bloco cirúrgico e de internação apresentaram em maior proporção redução de capacidade para o trabalho, grupo no qual foi verificada uma alta prevalência de distúrbios osteomusculares (Raffone, Hennington, 2005).

Outro estudo realizado junto a cem trabalhadores de enfermagem das unidades da clínica médica e cirúrgica deste HU, constatou que 35\% dos trabalhadores apresentam índice de capacidade inadequada para o trabalho, que pode ser atribuído a fatores relacionados ao processo de trabalho e à doenças, como as musculoesqueléticas (Silva, 2011).

Ainda, tivemos grande procura dos funcionários do Pronto-socorro adulto. Tal fator pode estar relacionado à especificidade do ambiente e do tipo de assistência prestada em atendimento emergencial, já que se trata de um ambiente de trabalho com constantes constrangimentos de tempo para realização de atividades, sendo considerado por alguns autores como uma das áreas do hospital com maior complexidade de assistência e com maior fluxo de atividades de profissionais (Gomes, 1994; Almeida, Pires, 2007). Neste HU, devido a mudanças na política interna e fechamento de serviços externos, houve um aumento importante de demanda para serviços de emergência de adultos. Assim, pode-se inferir que um dos principais problemas que esses trabalhadores enfrentam é a superlotação em decorrência da procura contínua dos usuários pelo serviço, ocasionando elevadas cargas de trabalho.

Ilustra esses achados o estudo conduzido por Loiola e Felli (2007), realizado junto aos trabalhadores de enfermagem desta unidade, onde se evidenciou que mais de $95 \%$ dos trabalhadores apresentaram dor osteomuscular nos últimos 12 meses, sendo a região da coluna lombar o local de maior acometimento.

Com relação às profissões, encontramos: 


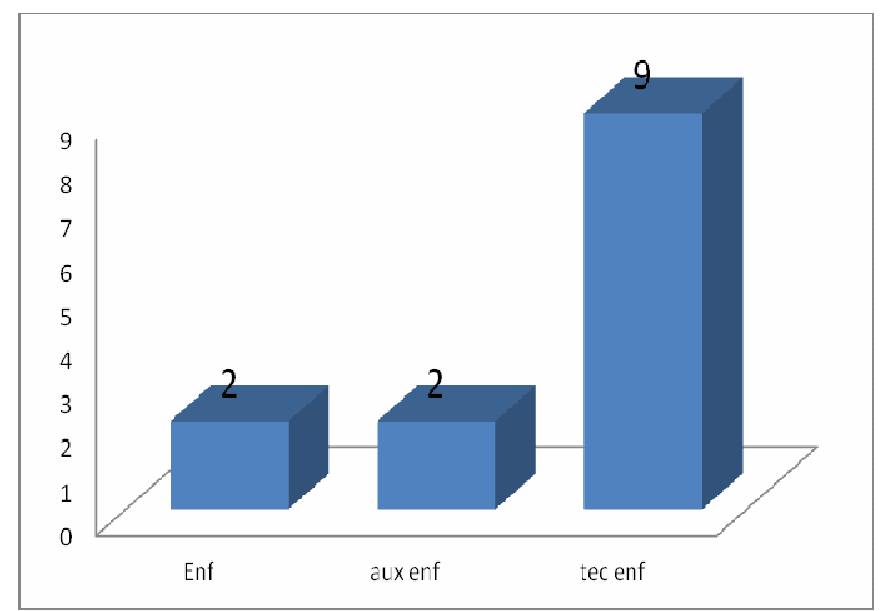

Figura 2 - Distribuição dos sujeitos participantes do estudo, segundo as categorias profissionais, São Paulo - 2011

A distribuição de categorias nos grupos reflete a quantidade de funcionários da Enfermagem deste HU, que possui, em maior número, técnicos de Enfermagem.

Para compreensão da QV da equipe de Enfermagem e proposição de alternativas de melhora, julgamos ser essencial heterogeneizar as categorias, para que o conhecimento coletivo fosse partilhado entre aqueles que, mesmo realizando atividades de trabalho distintas, estão sujeitos à mesma organização de trabalho, dividindo muitas vezes os mesmos postos.

No momento da pesquisa, apenas um profissional - uma das enfermeiras possuía outro vínculo, sendo este relacionado à docência.

Além de encontrarmos idades mais avançadas dentre esses trabalhadores, verificamos que sete deles trabalham na instituição há mais de 15 anos e seis deles trabalham entre cinco e 15 anos nesse local. O tempo médio de trabalho na instituição é de 19 anos, o que denota o aparecimento dos sintomas no exercício de trabalho, uma vez que sofrem o impacto cumulativo das condições de trabalho.

As atividades de trabalho são, predominantemente, de assistência direta a pacientes, como verificado a seguir: 


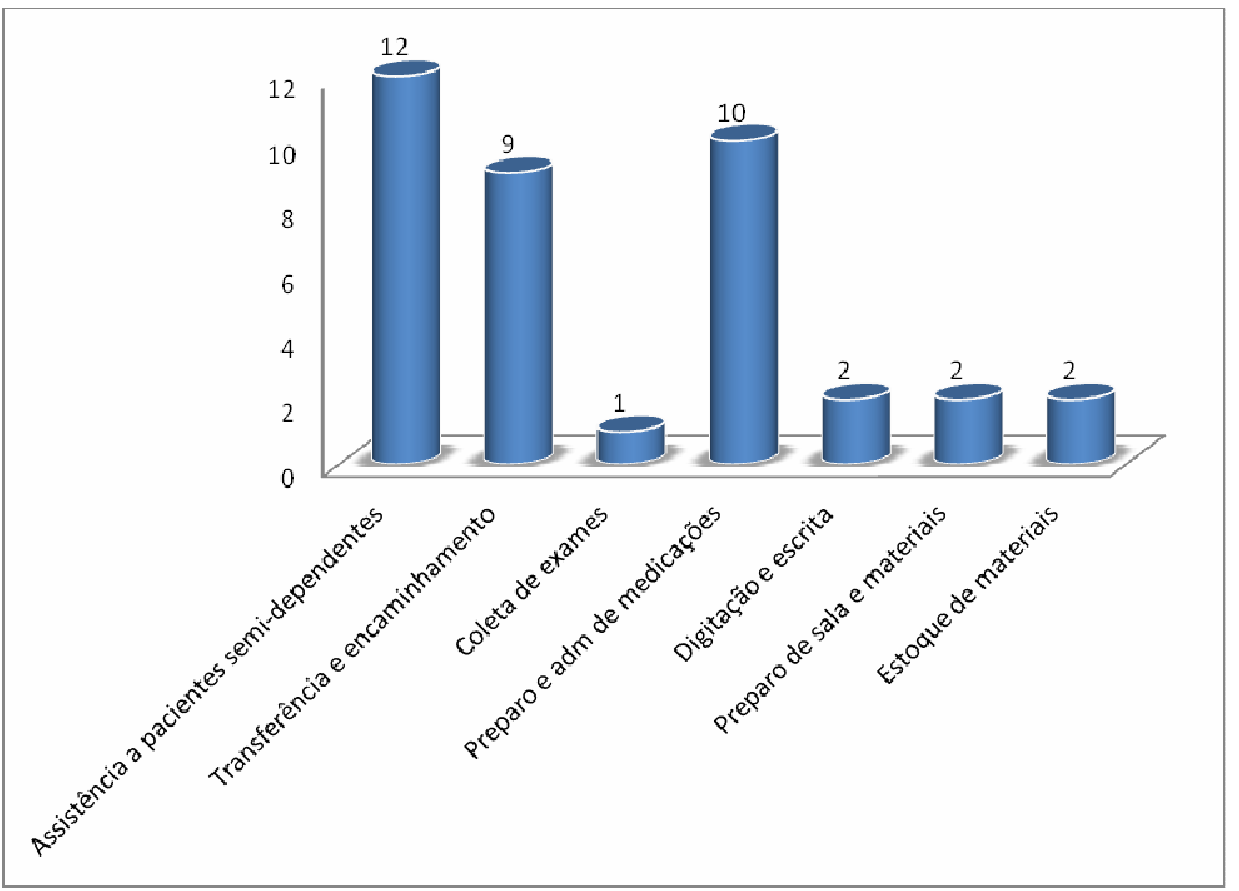

Figura 3 - Atividades de trabalho predominantes realizadas pelos funcionários de Enfermagem, São Paulo - 2011

Os dados da figura 3 deixam transparecer que, provavelmente, as atividades com maior risco ergonômico podem trazer malefícios ao sistema osteomuscular. Uma revisão de estudos sobre DORT em trabalhadores de Enfermagem selecionou 15 artigos e constatou que os principais fatores de risco enumerados pelos próprios trabalhadores de Enfermagem dizem respeito à organização do trabalho e respectivos aspectos ambientais e ergonômicos, sendo as atividades de trabalho de maior expressividade: a movimentação e o transporte de pacientes, posturas corporais inadequadas e os equipamentos inadequados e sem manutenção (Magnago et al., 2007).

Com relação aos diagnósticos, encontramos maior prevalência em quadros em regiões mais proximais de MMSS, com predominância de surgimento de sintomas de um a cinco anos. No gráfico a seguir, podemos observar a distribuição: 


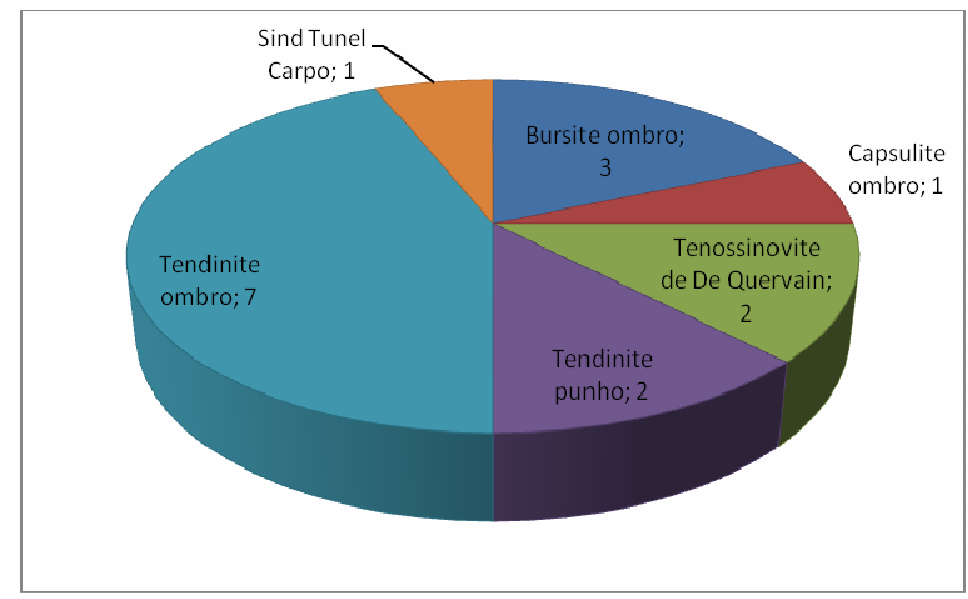

Figura 4 - Diagnósticos predominantes dos funcionários de Enfermagem, São Paulo - 2011

Tais resultados refletem a literatura atual, que mostra que, além de sintomas em coluna, os profissionais também apresentam sintomas em outras regiões do corpo, como os ombros e os punhos (Gurgueira, Alexandre, Corrêa Filho, 2003; Murofuse, Marziale, 2005; Ferrari, 2009; Martins, 2011).

Apesar da maioria de queixas vir da coluna, já desponta em alguns estudos a predominância de queixas relativas aos DORT em MMSS. Em uma avaliação qualitativa, 15 funcionários da enfermagem de diversos setores de um hospital da região Sul do Brasil, elencaram os MMSS como o local líder de queixas (Freitas et al., 2009). Murofuse e Marziale (2005), ao avaliarem prontuários médicos sobre atendimentos a pessoal de enfermagem, constataram que a patologia que afetou boa parte dos profissionais de enfermagem foi a sinovite e tenossinovite não especificada em MMSS e entre os técnicos de enfermagem, a única região do corpo afetada foi o membro superior.

Ferrari (2009), ao realizar a adaptação transcultural do instrumento Cupid, evidenciou que, de 40 profissionais da enfermagem, $50 \%$ sentiu dor em ombros nos últimos 12 meses, e atividades como pentear ou escovar os cabelos e tomar banho foram mencionadas como atividades com algum grau de dificuldade por metade dos trabalhadores com dor.

Dos trabalhadores deste estudo, cinco possuem restrições de trabalho que envolvem, em sua maioria, evitar manuseio de cargas físicas acima de $5 \mathrm{~kg}$, o que pode ser correlacionado com sobrecarga de trabalho em um tempo prolongado, com predominância de atividades manuais, exigindo sobretudo maior aplicação de força. 
A sintomatologia apresenta-se diversificada, embora observemos que apenas um dos indivíduos não se queixa de dor. As queixas relacionadas aos seus quadros podem ser vistas no gráfico a seguir:

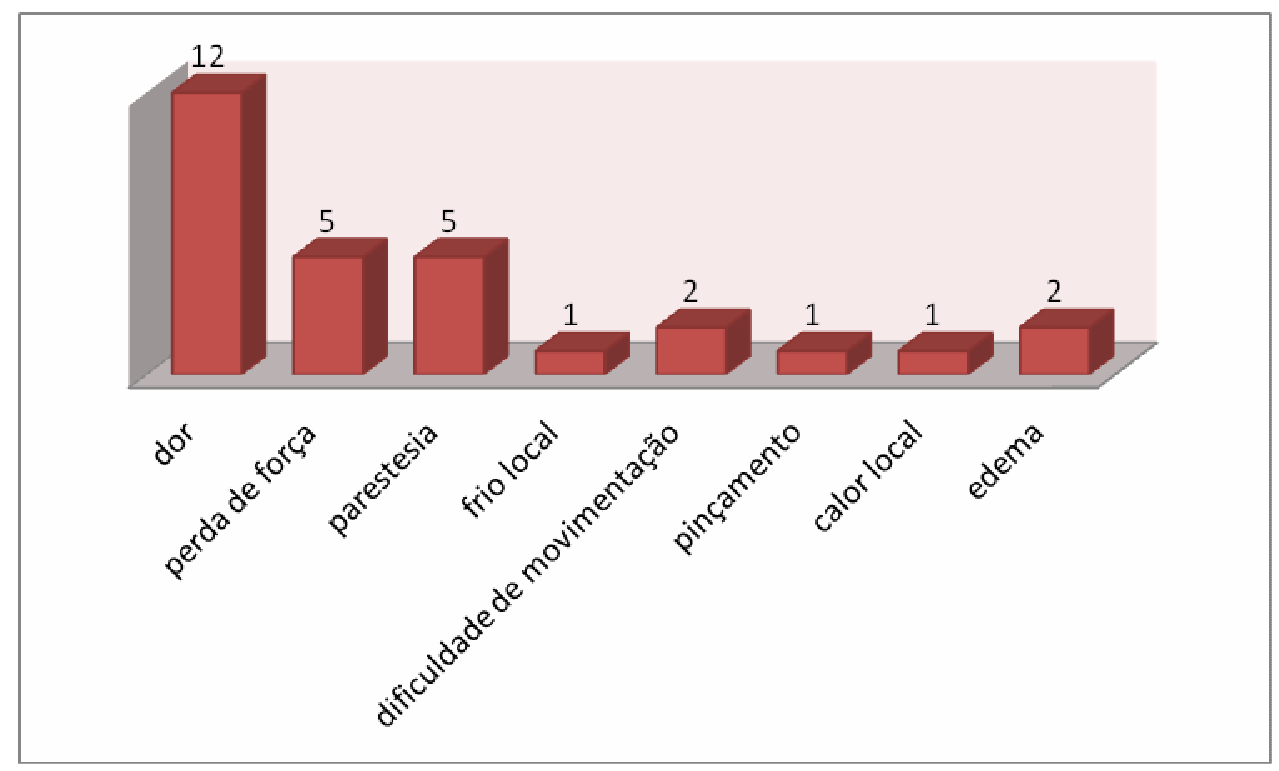

Figura 5 - Principais sintomas referidos pelos funcionários de Enfermagem, São Paulo - 2011

Além da dor, aparecem de maneira expressiva as queixas de perda de força e parestesias. A dor desponta como o sintoma de maior expressividade entre os portadores de DORT (Brasil, 2001b).

Todos relatam já ter procurado algum tipo de tratamento para seus quadros, tendo sido utilizados, em sua maioria, medicamentos anti-inflamatórios por mais de um ciclo. Além disso, mais da metade desses funcionários já foi submetida a tratamento fisioterapêutico e outros quatro buscaram práticas suplementares como acupuntura e prática de atividade física regular.

Além dos quadros de DORT, praticamente a totalidade dos pacientes sofre de doenças de base, sendo as mais expressivas: hipertensão arterial sistêmica (quatro pacientes), hipercolesterolemia (três pacientes), osteoartrose de membros inferiores (dois pacientes) e quadros de depressão (dois pacientes). Dos 13 sujeitos, oito fazem uso de medicamentos específicos para controle dessas doenças.

Devido à sintomatologia, muitos relatam dificuldades em realizar atividades de vida diária, como mostra o gráfico a seguir: 


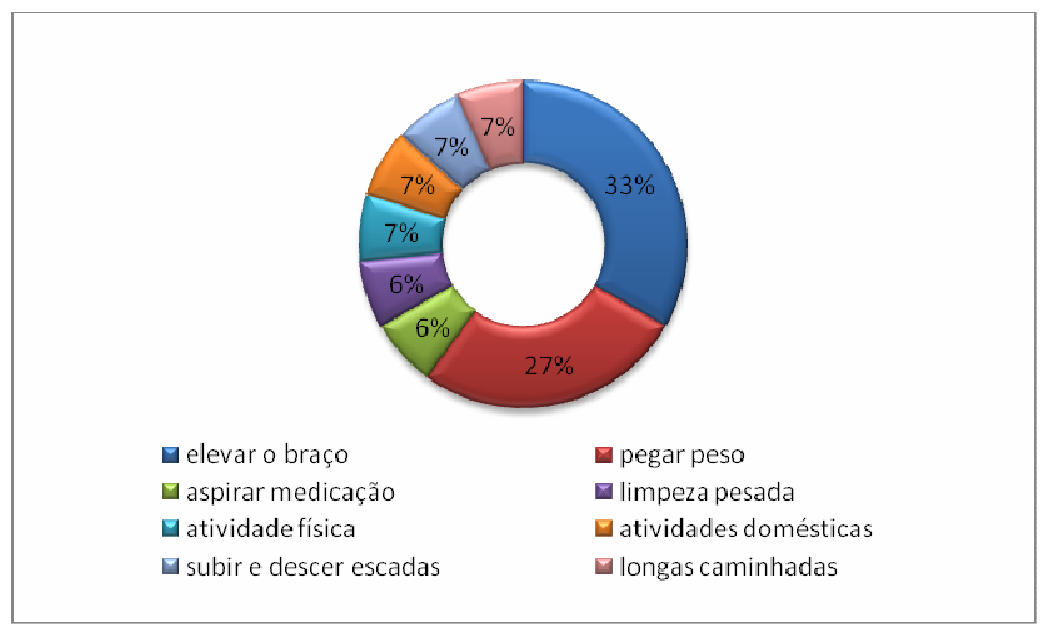

Figura 6 - Limitações em atividades dos funcionários de Enfermagem, São Paulo - 2011

Com relação ao maior número de queixas, a elevação de braços com dificuldade ocorre em tarefas corriqueiras do dia a dia, como cuidados com rosto e cabelos, estender roupas e guardar objetos no alto, e é bem provável que tais limitações guardem forte correlação com os diagnósticos e com a cronicidade destes. Recordamos que tais dados também foram mencionados no estudo de Ferrari (2009), onde aproximadamente metade dos trabalhadores de Enfermagem com dores em ombros tinham algum grau de dificuldade para vestir-se e cuidar dos cabelos, e $75 \%$ deles apresentaram dificuldades para realizar tarefas domésticas.

Além das impossibilidades cotadas, também são referidas diversas modificações no cotidiano por alguns dos trabalhadores; quatro deles referem realizar atividades de maneira adaptada - dividindo tarefas ou utilizando materiais para suporte -, três referem lentidão na execução de tarefas, quatro referem mudanças no padrão de sono-vigília e de humor e três viram-se obrigados a diminuir suas atividades devido às suas limitações.

Com relação às atividades de lazer cotidianas, cinco trabalhadores relatam não realizar atividades de lazer de modo corriqueiro. Os outros oito realizam lazeres mais esporádicos - cerca de uma a duas vezes na semana, mas de forma não regrada - em atividades como: prática de atividade física, leitura, assistir televisão, ir a aulas de teatro, ir a aulas de canto, dormir e utilizar o computador como entretenimento. 


\subsection{DADOS DOS GRUPOS FOCAIS}

Já na fase pré-analítica, percebemos o caminhar dos grupos em três momentos diferentes. A primeira fase do percurso foi de refinamento do olhar, na qual os participantes conseguiram perceber-se melhor, perceber o ambiente que os cerca e a influência desses aspectos em seu processo de saúde-doença. Isso permitiu a construção de formas de cuidado, aspecto observado na segunda fase do percurso, seguida de respectivas modificações nas formas de ser e de agir.

As falas registradas nos grupos focais, após análise temática, permitiram apreender quatro categorias para discussão, representadas no quadro a seguir: 


\begin{tabular}{|c|c|c|}
\hline Categorias & Temas & Unidades de Significado \\
\hline Existindo com dor & $\begin{array}{l}\text { História de vida, a dor mediando } \\
\text { expectativas, dor e estado emocional }\end{array}$ & $\begin{array}{l}\text { “(...) eu sou S2 e de algum tempo pra cá comecei sentindo algumas dores que começou assim na mão... } \\
\text { mas que agora se fixou no ombro" } \\
\text { "Tô aqui pra... aprender a... trabalhar... sem sentir dor..." } \\
\text { “(..) ai eu comecei a ficar ansiosa... ansiosa e foi aumentando essa dor, foi aumentando..." }\end{array}$ \\
\hline QV é não ter limitaç̃̃es & QV é equilíbrio, QV é não ter dor & $\begin{array}{l}\text { "Pra mim é o equilibrio, né? Para mim é quando você tá bem, fisicamente, emocionalmente e } \\
\text { espiritualmente" } \\
\text { "(...) qualidade de vida é viver sem dor..." }\end{array}$ \\
\hline $\begin{array}{l}\text { Meu trabalho } \\
\text { influenciando na minha } \\
Q V\end{array}$ & $\begin{array}{l}\text { Sobrecarga de trabalho, equipamentos de } \\
\text { trabalho, inadequações no processo e } \\
\text { organização de trabalho }\end{array}$ & $\begin{array}{l}\text { "(...)ah, é o tempo que a gente fica aqui, agente fica bastante tempo no hospital..." } \\
\text { "Então aqui eu faço o serviço... o meu, o de uma colega que saiu o de mais um técnico que } \\
\text { retiraram(...)" } \\
\text { "(...) cadeira de banho, triste aquelas cadeiras de banho..." } \\
\text { "(...) a farmácia faltou funcionário e tem que buscar medicação... ai a gente vai busca...(..) a farmácia } \\
\text { erra (...). e a enfermagem tem que se virar e ir lá buscar..." }\end{array}$ \\
\hline $\begin{array}{l}\text { Cuidando } \quad \text { e sendo } \\
\text { cuidado }\end{array}$ & $\begin{array}{l}\text { Promoção da saúde, aspectos favoráveis no } \\
\text { ambiente de trabalho, atendimentos de } \\
\text { saúde, preocupações com pares, satisfação, } \\
\text { processo grupal, conscientização, } \\
\text { mudanças no cuidado, o viver e o fazer } \\
\text { sem dor }\end{array}$ & 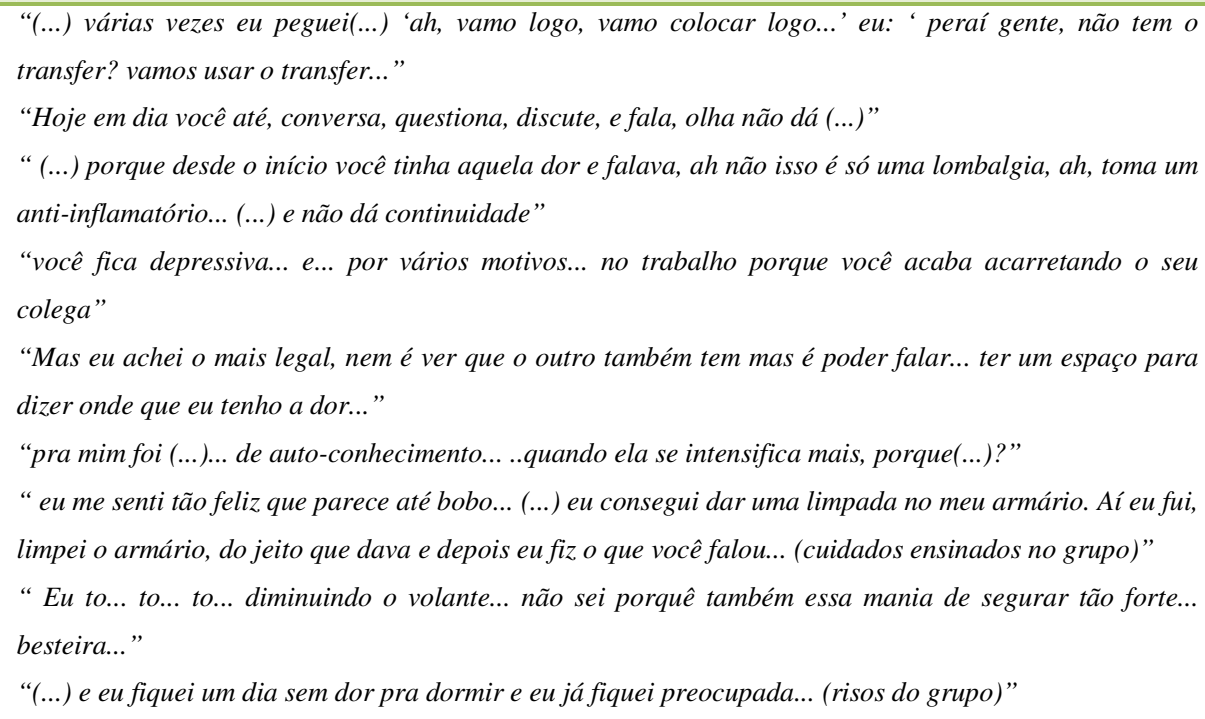 \\
\hline
\end{tabular}

Quadro 1 - Categorias elencadas pelos trabalhadores de Enfermagem nos grupos focais, São Paulo - 2011 
Nos parágrafos a seguir, discorreremos de maneira mais aprofundada sobre cada categoria e seus respectivos temas, bem como ilustraremos com unidades de significado mais recorrentes e relevantes.

\section{Primeira categoria: Existindo com dor}

Ao serem requeridas as apresentações iniciais, como nome, local de trabalho e as justificativas para frequentar os grupos focais, o discurso do grupo enfatizou muito a história de diagnósticos e, mais especificamente, da dor que os sinaliza quase diariamente; a dor parece identificar os sujeitos do grupo, como evidenciado nas unidades de significado a seguir:

\footnotetext{
"Há uns três anos mais ou menos que tudo começou com o ombro direito, mas aí eu passei a fazer as coisas com o ombro esquerdo... e acabou passando pro ombro esquerdo e cervical... irradia, né? Então eu tenho muito choque, eu mal sinto o ombro direito agora, às vezes dá uma dor forte, mas aí ela para rápido, passa rápido" $\mathrm{S} 1$

“(...) eu sou S2 e de um certo tempo pra cá comecei sentindo algumas dores que começaram assim na mão... mas que agora se fixaram no ombro; porém... irradia para toda a cervical, ombro direito, né, que irradia para a cervical e ombro esquerdo..." S2

“(...) e de um ano pra cá comecei a sentir umas dores no ombro, que vêm pro cotovelo e depois vêm pro punho... e assim... tô aprendendo a trabalhar com a dor, porque tem dia que você sente muita, muita dor... "S3
}

É como se a dor já fizesse parte da personalidade, como algo não grato, algo que não é desejado, mas que se tornou mandatório na vida desses trabalhadores. Viver sem dor parece, nesse momento grupal e temporal, praticamente impossível, sendo esse sintoma indissociável da constituição humana.

O objetivo relatado para estar no grupo englobou basicamente a busca de formas para amenizar a dor ou para conhecer alternativas a fim de tentar trabalhar com menos dor ou realizar algumas atividades de trabalho, domésticas e de lazer de maneira adaptada.

“(...) aprender a... vim... aprender como lidar com a dor... não tanto com a dor, mas como eu amenizar essa dor." S4 
“(...) e... o meu intuito de estar aqui... também... tentar aprender alguma coisa com que amenize... com que previna... assim, com que previna tudo que eu venho sentindo..." S2

“(...) essa oportunidade da Ana Paula é, assim, muito legal... pra gente poder prevenir e ter algumas estratégias pra gente poder melhorar" S5

“(...) pra melhorar... tipo... a postura ou pra melhorar algum movimento que eu esteja fazendo errado e diminuir a dor no ombro..." S6

" Tô aqui pra... aprender a... trabalhar... sem sentir dor..." S7

O interessante é que a grande maioria não almeja a cura do quadro, mas, sim, espera aprender a sofrer menos ou a prevenir pioras, o que implica numa adequação das expectativas desses sujeitos, que fogem do padrão de pacientes que procuram um tratamento buscando a resolução total dos sintomas.

Alguns parecem ter a esperança de que alguém olhe para eles e reforce alternativas que já conhecem, mas que por vezes minimizam em grau de importância ou esquecem de executar. O grupo parece então funcionar como um reforço ou um grande alerta, cuja finalidade pode ser sempre manter os pacientes numa linha de bons hábitos musculoesqueléticos.

\footnotetext{
“(...) porque justamente pra ver se melhora essa situação, pelo menos com relação à postura... que a gente tenta até não ficar em determinadas posturas, mas acaba ficando, né?..." S8
}

Ao longo das sessões, pareceu também ter feito bastante sentido conhecer a relação do estado emocional com pioras ou gatilhos no aparelho osteomuscular; as falas da pesquisadora sobre o tema resultaram em acenos de concordância. Percebese que, em momentos ainda iniciais, foi despertado o interesse das pessoas para discussão desse assunto.

\footnotetext{
“(...) tinha coisas no primeiro slide que você mostrou que eu não sabia desse aspecto emocional...” S5

“(...)pra mim também foi importante isso...” S2
} 
“(...) eu comecei a sentir muita dor... mas não era no ombro que eu estava acostumada... era no outro... mas por que, se começou a doer agora? porque é aquela coisa de sobrecarga... aí eu pensei assim: ai, meu Deus, como que eu vou trabalhar amanhã... aí eu comecei a ficar ansiosa... ansiosa e foi aumentando essa dor, foi aumentando... aí eu falei: e agora? tomo o anti-inflamatório ou não tomo? eu falei assim: não vou tomar o anti-inflamatório, porque tem o emocional junto... aí eu peguei, só fiz compressa, fiquei no banho bem quente assim ... deu uma aliviada boa..." S4

As falas apontam para o estado emocional como desencadeante da dor. Alguns estudos comprovam que diversos componentes do processo de trabalho, como alta demanda, estresse, tarefas monótonas e pressão são reconhecidamente importantes no processo saúde-doença dos DORT (Bongers et al., 2002). Alguns descrevem exemplos de componentes psicossociais como satisfação no trabalho, apoio da equipe e chefia e ainda, características pessoais (Joiling et al.,2008)

\section{Segunda categoria: Qualidade de vida é não ter limitações}

Quando instigados a pensar sobre a definição do termo qualidade de vida, os trabalhadores a conceituam diferentemente, porém de forma interdependente. A princípio, concordam que ter qualidade de vida é poder desfrutar de bens materiais e emocionais que a vida oferece. Encontramos a seguir as falas que mais se repetem com relação à percepção do indivíduo sobre sua vida:

"É estar bem... Espiritualmente, financeiramente... você ter condições de manter as suas coisas dentro de casa... você ter e... você ter vontade de passear e ir passear... se manter bem..." S3

"Pra mim é o equilíbrio, né? Para mim é quando você está bem, fisicamente, emocionalmente e espiritualmente... Tá, é aquele equilíbrio, porque não adiante estar bem fisicamente e estar com a minha cabeça destrambelhada..." S2

"É você... ter a sua, sua vida lá fora, mas também, assim, saber usufruir... passear, viajar, se divertir, curtir sua família..." S9

As falas corroboram com dados obtidos em dois estudos sobre percepções de QV em enfermeiros sem DORT. Araújo, Soares e Henriques (2009) avaliaram 12 
enfermeiros de um HU na Paraíba e constataram que o discurso coletivo sobre QV a define como um estado de harmonia e de vida com equilíbrio nas esferas biopsicossocioespirituais. Da mesma forma, outros 26 enfermeiros funcionários de um hospital geral da região sul do Brasil correlacionaram QV à saúde, bem-estar físico e mental e lazer, dentre outros aspectos (Cecagno et al.,2003).

O fato é que usufruir desses prazeres torna-se delicado na vigência de um quadro doloroso. Fica evidente que ter qualidade de vida é ter um equilíbrio em todas as esferas da vida, mas que no momento não está ocorrendo devido à existência de limitações, sendo a principal a dor. Dessa forma, encontramos que a dor é mediadora dos objetivos, expectativas, padrões e preocupações desse pacientes:

\footnotetext{
"estar sem dor você faz muita coisa... então, pra mim, qualidade de vida é estar sem dor..." S4

"qualidade de vida é viver sem dor..." S10

"Por isso que eu acho que a qualidade de vida é você não ter tantas limitações, porque se você... porque se você tem... por exemplo, o caso da dor, que é principal de todos aqui..." S1

“...é você poder fazer todo tipo de atividade, laboral, de lazer familiar, é... que você consiga fazer, mesmo com algumas restrições, mas que você consiga fazer..." S11
}

Mais próximo das definições oriundas das reflexões desses grupos focais, encontramos maneiras semelhantes de conceituação desse grupo com o conceito de "Qualidade de Vida Relacionada à Saúde (QVRS)" proposto por Guianchello (1996) e Auquier, Simeoni e Mendizabal (1997), já que o valor atribuído à vida por esses sujeitos é fortemente influenciado pela presença de um sintoma que é parte preponderante - de seus distúrbios.

O tema "dor" carrega grande relevância e permeia todas as falas relacionadas à qualidade de vida, e tal achado também pode ser encontrado em pesquisas quantitativas, realizadas junto a trabalhadores da Enfermagem com DORT.

Em dois estudos que pesquisam a QV em profissionais da Enfermagem acometidos por DORT, os dados colhidos apontam inclusive para uma alteração da qualidade de vida (Célia, Alexandre, 2003; Gurgueira, 2005). Ambos os estudos foram realizados em hospitais e utilizaram o questionário padronizado SF-36; os escores médios deste apresentam-se reduzidos em algumas dimensões, em especial 
no aspecto dor corporal, de 41,5 e 62,8, respectivamente (Celia, Alexandre, 2003; Gurgueira, 2005). Ressalta-se que, no estudo realizado por Gurgueira (2005), foram encontrados escores relativamente maiores e os funcionários já possuíam laudos médicos com restrições de trabalho, o que significa que muitas das atividades causadoras de dores e desconforto podem ter sido eliminadas do cotidiano laboral desses funcionários.

A pontuação máxima de uma dimensão no SF-36 é de 100 pontos. Ao compararmos os resultados dos estudos da população de enfermagem com DORT aos escores obtidos pela população em geral trabalhadora do município de São Paulo, observamos diferenças discrepantes, mesmo naqueles funcionários com restrições de trabalho, já que o escore médio de dor é de 73,8 (Kimura et al.,2002).

A existência da dor tem uma interferência tão importante na qualidade de vida que afeta outras de suas dimensões, como o sono. É voz corrente dos trabalhadores que, ter noites maldormidas, ou, ainda, agitadas, faz com que a qualidade de vida seja ainda mais prejudicada.

“(...) é... eu, por exemplo, não tenho o sono bom, eu durmo e me sinto satisfeita porque sei que só vou dormir aquilo mesmo." S1

"Ter qualidade de vida é estar sem sono... é... descansada também... dormir... é, às vezes você vai dormir e não acha uma posição boa." S4

"(não dormir direito interfere na minha qualidade de vida e) de sono, de sono, porque eu não durmo direito... eu sou uma pessoa que eu preciso dormir muito; então, eu acordo várias vezes... estou ficando uma pessoa com insônia..." S2

Ainda no tocante à questão da dor, alguns pontuam o fato de se preocuparem não apenas com a existência da dor no momento presente, mas também demonstram extrema preocupação sobre situações futuras - a curto e médio prazo -, nas quais a dor poderá surgir ou aparecer em maior intensidade. Tal fato parece implicar de maneira brutal no planejamento de atividades de lazer, que deixam de ser realizadas, pois há um temor do "fantasma da dor".

“... e parece que realmente é isso, você quer viver sem ter medo de pensar... que nem é assim... ah, tá, vou viajar e vou pra casa do meu pai... mas e se começar a doer no meio do 
caminho, então eu tenho que pegar 'numseioquê'... e isso vai.. e isso vai te acarretando um monte de pensamentos..." S10

“... e também é você não estar pensando na dor... você conseguir se distrair (...) é, não ficar pensando, poxa, agora a dor aliviou, agora eu estou sem dor..." S4

"você está dormindo e acorda com dor... então, aí, já complica todo o seu dia, te limita de fazer qualquer outra coisa... e parece que realmente é isso, você quer viver sem ter medo de pensar nela." S10

Pensar na possibilidade de a dor acontecer já é algo bastante amedrontador e que leva os pacientes muitas vezes a desistir de projetos pelo temor desse sintoma. Dessa forma, pode-se pensar que esse sintoma impede almejar uma qualidade de vida melhor; enquanto estiver presente, trará consigo impossibilidades no presente e no futuro.

Em se tratando de reflexões a longo prazo, alguns relatam desesperança em planejamentos de seu futuro quando aposentados, já que imaginam que seus quadros atuais estarão ainda piores daqui a poucos anos.

\footnotetext{
“(...) então coisas que você vai fazer, que você faz aqui, acaba interferindo muito lá fora porque sua qualidade de vida vai ser totalmente diferente do que você programou... então você pensa: 'ah, quando eu me aposentar eu vou fazer isso, isso, isso'... só que quando você começa a perceber que você tem restrições, começa a ter dores, isso e aquilo, você começa a limitar e, lá na frente, cria um stress incrível e você fica imaginando: 'poxa, eu vou chegar lá na frente, mas não é bem o que eu pensava, eu vou ter restrição disso, vou ter restrição daquilo, não vou conseguir pegar peso'." S8
}

Muitos relatam tentar buscar artifícios - atividades de lazer, amparo na família, viagens - para lidar melhor com a dor, mas parecem acabar sucumbindo perante a existência dela. Tem-se então que o indivíduo perde sua autonomia para lidar com a dor; ela passa a mediar as escolhas deste e a permitir ou não a execução de atividades.

Ter DORT é lidar com o fracasso cotidiano de se ver incapaz e de observar o declínio de suas potencialidades relacionadas ao fazer. Surgem então limitações físicas que acabam trazendo consequências emocionais, como depressão, apatia, tristeza, choro expresso e sensação de invalidez. São citadas limitações em papéis 
profissionais e naqueles também exercidos no cotidiano doméstico, nos quais são mencionadas inclusive atividades de cuidados pessoais básicos, que ou deixaram de ser realizadas, ou são realizadas devido à forte influência do quadro doloroso.

"é mais o ombro esquerdo que eu tenho realmente assim, limitações assim, é... pra fazer as coisas de casa...” S3

"Muita dificuldade pra fazer meu serviço doméstico do dia a dia, coisas simples, básicas... mas muita dificuldade... às vezes até para lavar o cabelo..." S2

“(...) aí em casa eu preciso estender uma roupa, lavar uma louça, eu não consigo mais fazer do jeito que eu tinha que fazer, né? E isso começa a mexer com a parte emocional também, mexe com a parte emocional da pessoa, porque você acha que você vai começar a ficar inválida." S5

“(...) atrapalha sim e muito... por exemplo... pra passear... se eu quero, se eu vou ao clube e eu quero brincar na piscina e eu quero... ai, eu não posso levantar o braço porque eu já sei que se eu levantar muito vai doer... aí eu não posso fazer aquilo porque vai doer... então assim... tudo isso, eu acho que me deixa, me deixa... muito chateada..." S1

Tais achados assemelham-se àqueles colhidos por Leite, Merighi e Silva (2007), que investigaram o cotidiano de seis trabalhadoras de Enfermagem com DORT. Os relatos das mulheres entrevistadas revelam que a cronicidade da doença traz experiências de modificações no dia a dia, impostas pelas limitações e pelas incapacidades, alterando significativamente o cumprimento de tarefas básicas e simples e sua relação com o mundo.

\section{Terceira categoria: meu trabalho influenciando na minha qualidade de vida}

Parece também haver uma significativa influência do trabalho na definição de qualidade de vida para os sujeitos em questão. Fatores como sentimento de obrigação em priorizar mais o trabalho do que outros aspectos da vida, o que ocasiona um maior tempo despendido na instituição, são geradores de culpa e de aspectos negativos. 
"Minha qualidade de vida não está boa, porque eu tô dando mais prioridade pro meu trabalho do que pra minha família, né? Eu trabalhar também é importante, sim, é muito importante... só que a gente precisa ter um lazer..." S5

“(...) passear, viajar, se divertir, curtir sua família, não achar que o serviço é o todo, sua vida inteira..." S9

Fica evidente nos diálogos que a quantidade de tempo que os trabalhadores permanecem na instituição os incomoda e afeta negativamente a vida fora do trabalho. Mesmo não estando no ambiente de trabalho, são comuns preocupações com ele:

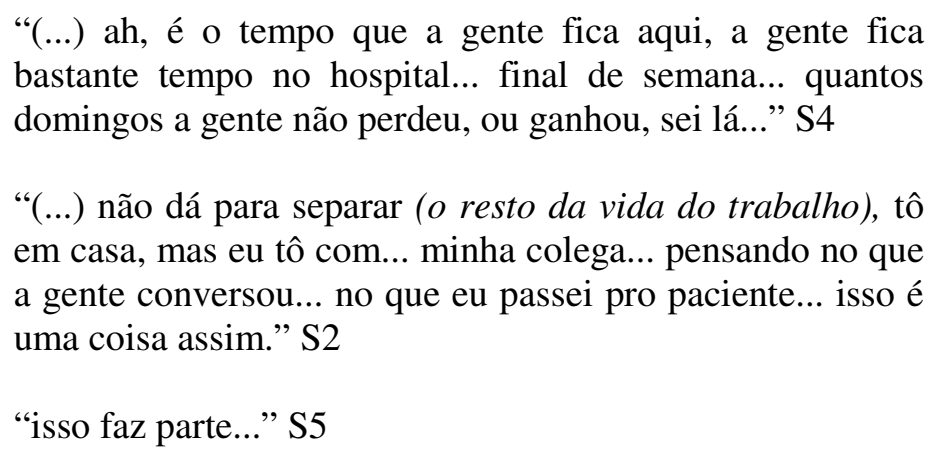

Fatores estressores como excesso de trabalho também foram queixas coletivas de 15 enfermeiros trabalhadores de um hospital no Rio Grande de Sul sujeitos de um estudo qualitativo (Araujo, Soares, Henriques, 2009).

Da mesma forma, os participantes são unânimes em relacionar diversos equipamentos utilizados para realizar atividades de assistência direta a pacientes macas, cadeiras de rodas, cadeiras de banho - que se encontram em péssimo estado de conservação e que, por isso, apresentam um manuseio difícil.

\footnotetext{
“(...) até a manutenção das rodinhas, né, da cama, como a gente com dor presta atenção em detalhes... nossa! essa cama aqui tá muito pesada, tem que arrastar...” S4 “(...) cadeira de banho, triste aquelas cadeiras de banho..." S3

“Sabe aquelas macas emperradas?" S2
} 
Frequentemente, os discursos revelam situações de sobrecarga psíquica, representadas especialmente no estresse ao lidar com outras equipes da instituição:

“(...) ah, esqueci, o pessoal da limpeza, terceirizada... que isso está sendo difícil, está...mas pelo menos tem.” S5

“(...) então, tem essa questão aí (....... e essas terminais... apesar da gente não precisar fazer mais... elas não vão limpar na hora que a gente quer que elas limpem." S3

"Isso é um stress, principalmente pro enfermeiro... porque o enfermeiro tem que correr atrás disso, porque o PS está lá embaixo querendo vaga." S5

“(...) e tem chefe de plantão que não quer saber... 'interna'... 'eu não quero nem saber, isso é problema de vocês'.” S5

“...na farmácia faltou funcionário e tem que buscar medicação... ai a gente vai, busca... só que tem um porém... a farmácia erra e manda medicação errada... e a enfermagem tem que se virar e ir lá buscar... e isso se torna estressante porque você tem uma rotina no plantão que você tem que fazer ..." S8

Não só o tempo em demasiado dedicado ao trabalho é relatado, mas também a forma de distribuição de atividades laborais cotidianas. Se há um descompasso ou desigualdades na divisão das diversas tarefas de trabalho, é gerada uma sobrecarga que também influencia a qualidade de vida:

\footnotetext{
"Então aqui eu faço o serviço... o meu, o de uma colega que saiu, o de mais um técnico administrativo que eu não tenho... eu tenho técnico que retiraram, eu tenho técnico que está de férias... então na realidade eu tenho um acúmulo de atividades que não são da enfermeira... porque, o meu, eu consigo fazer... não é que eu não goste, eu gosto do que eu faço... eu não gosto é de ter que ficar fazendo coisas de outras pessoas..." S11
}

Em uma revisão de 15 artigos sobre a temática DORT em Enfermagem, fatores de organização do trabalho, ambientais e ergonômicos inadequados - aqui incluídos equipamentos inadequados e sem correta manutenção - são alguns dos mais lembrados pelos trabalhadores com DORT como fatores de risco para a maior ocorrência de sintomas osteomusculares (Magnago et al., 2007). Da mesma forma, 34 profissionais de um centro municipal de saúde carioca que realizaram um estudo sobre a qualidade de vida no trabalho elencaram como preponderantes para uma 
melhor qualidade de vida no trabalho o processo de trabalho mais bem estruturado e organização na unidade de trabalho (Farias, Zeitoune, 2007).

Ainda nesse tema, foram mencionadas as questões de pessoal no setor, como ausências não previstas ou escala insuficiente para a demanda, que têm como resultados excesso de trabalho, desgaste e aumento da dor.

“(quando a equipe está completa) então ajuda bastante... tem dia que a gente ficou em duas, mas, então assim, a maioria das vezes a gente ficou em três; então já ajuda bastante... acho que isso relaxa tudo, né? a sua preocupação, sua correria..." S1

“(...) que nem, eu dei plantão domingo e teve três funcionários que não puderam estar presentes... então, quer dizer, você teve que trabalhar dobrado..." S12

"No feriado eu trabalhei o dia inteiro... e assim, os pacientes muito mais pesados... paciente pesado, funcionário que faltou... assim, já estava no limite e ainda faltam dois funcionários..." S8

Igualmente, é notada como positiva a escala completa, tanto para conforto mental quanto físico.

“...é e esses três dias foram mais calmos lá no prontosocorro e eu estou me sentindo melhor... quer dizer, não é que é mais calmo... aumentou um pouquinho funcionários..." S13

Em um dos grupos, o tema sobre dificuldades na organização da escala de folgas é citado como fator que influencia negativamente a qualidade de vida.

“(...) faço um complemento; assim, quando você tem uma programação, que você vai viajar assim, poderia ter um pouquinho mais de colaboração em escalas, facilitar a vida um pouco... a vida da pessoa (...) a gente vê casos difíceis... que geram vários problemas..." S7

"E o que isso gera?" pesquisadora

"Tensão" S7

"Stress... A pessoa fica doente." S9

“(...) é... aquela coisa, eu gosto de você e não gosto de você, (apontando para os membros do grupo). Você pode (tirar folga), você não, entendeu?" S11 
Os relatos concluem que o excesso de trabalho leva a um quadro de fadiga tão importante que acarreta falta de disposição para realização de outras atividades prazerosas.

“(...) a gente sai daqui, qual a disposição que a gente tem?" S2

"Acho que diminui a minha disposição, sabe... me incomoda assim... assim, me atrapalha de eu... então eu gostaria de fazer alguma coisa à noite...sabe, mais eu estou assim, ou eu estou muito cansada... tem dia que eu não aguento de dor na perna, de tanto que eu fiquei... então assim ... acabo não fazendo outras coisas, eu deixo de fazer..." S11

Trabalhadoras com vínculos duplos ressaltam essa questão e afirmam que a recompensa financeira obtida pela maior dedicação à profissão não supera aquilo que em suas vidas se torna ausente: tempo com a família, momentos de descanso, episódios de lazer, enfim, não existem momentos para vivenciar os pilares do que esses grupos entendem como QV.

“(...) mas se eu fosse parar pra pensar assim, agora, pra mim, o que seria de qualidade de vida é não trabalhar em dois empregos, não trabalhar de final de semana, trabalhar seis horas por dia e ganhar o suficiente pra manter a minha casa e cuidar um pouco de mim." S5

"Eu, por exemplo, tinha dois empregos até uns anos atrás... eu saí exatamente do outro emprego quando eu comecei com esse problema no braço (...) aí eu comecei a passear mais... comecei a fazer coisas que eu gosto e eu assistia muito filme... eu sou vidrada em filme!" S1

“(...) eu arrumei outro emprego em 2009 e trabalhei em outro emprego por quase dois anos... é... mas aí eu vi que as coisas... é ... melhora o seu lado financeiro, mas a sua qualidade de vida piora totalmente... porque você tem mais dinheiro... mas não tem disposição para gastar... (...) e aí eu comecei a ver... tipo... eu tenho uma filha de 13 anos... e aí eu comecei a ver que dar, que dar iPod, que dar computador, que tudo isso não estava suprindo as necessidades dela, que ela queria mais a minha presença..." S10

Os participantes desta pesquisa sentem os efeitos deletérios de apenas um vínculo empregatício, colocando também o trabalho exercido como um impeditivo 
para a realização de atividades extraprofissionais. Ter bons hábitos de saúde não é possível não apenas pela questão de tempo, mas pela questão de ausência de disposição e energia; as cargas psíquica e física são colocadas como extenuantes, o que implica numa qualidade de vida prejudicada, já que usufruir do que se gosta fica bastante difícil.

Notamos, outrossim, que a remuneração de dois empregos não tem um papel preponderante neste grupo de pacientes estudados, contrariando estudos que afirmam que o aspecto financeiro está atrelado a uma melhor QV (Cecagno et al, 2003). Ressaltamos que tal fator pode se dever ao salário recebido nesse HU, já que este encontra-se acima da média dos demais locais. Em muitos estudos, os trabalhadores são obrigados a buscar um novo vínculo de trabalho, devido à obtenção de renda insuficiente com apenas um salário.

A noção que os pacientes têm de qualidade de vida aproxima-se de um novo eixo conceitual, já que as queixas sobre a organização do processo de trabalho e a influência disso no dia a dia evocam o conceito de Qualidade de Vida no Trabalho (QVT). As falas dialogam com a definição de QVT. Logo, concluímos que, para portadores de DORT da equipe de Enfermagem, a QV é indissociável da QVT, tal como exposto por Campos e David (2007). Os efeitos do trabalho afetam as demais esferas da vida.

Concordamos com Morris, Perez e McNoe (1998) quando afirmam que conceituações de qualidade de vida realizadas por determinados grupos de pessoas que enfrentam situações adversas semelhantes - portadores de câncer, diabetes, hipertensão e DORT - fornecem informações valiosas sobre quais são as estratégias de promoção de saúde mais eficazes em serviços de saúde. Profissionais da área que pretendam abordar a temática da QV em Enfermagem devem, portanto, enfocar questões individuais e questões relativas ao trabalho, para que a integralidade do termo QV nessa população seja abordada e para que estratégias de melhoria sejam propostas.

\section{Quarta categoria: cuidando e sendo cuidado}

Muitos citam saber da existência de estratégias de manutenção de uma boa saúde física e mental, mas menosprezam a importância de torná-las hábitos. 
Saber das posturas corretas e da alternância destas, inserir pausas no dia a dia, bem como realizar transporte de paciente em maca em duplas não significa realizálas.

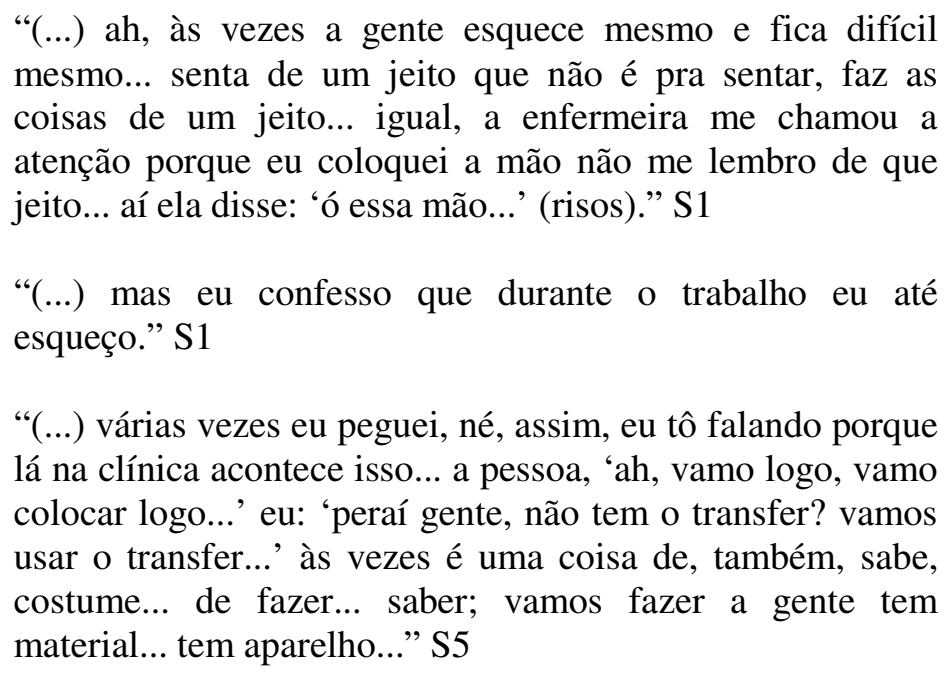

São citadas atividades como ir ao teatro, ouvir música, fazer atividades físicas diversas, mas nunca há uma prioridade para que isso seja realmente parte da vida dos trabalhadores. Alguns dos empecilhos nomeados, em menor grau de importância, são tempo e dinheiro. Mas fica explícito que existem dois aspectos principais para a não adoção de estratégias regulares de manutenção de saúde e bem-estar: o desgaste físico e emocional e o comportamento pessoal, que a longo prazo leva o trabalhador a cultivar hábitos ou vícios ruins.

As falas trazem em si bastante culpa e pontuam que muitas vezes sabem o que é necessário ser feito, mas acabam não realizando:

“eu acho que não temos tempo, não priorizamos...” S2

Alguns ainda correlacionam esses vícios comportamentais ao histórico da Enfermagem, onde antigamente relatam que deveria ser feito com ou sem auxílio.

\footnotetext{
“(...) porque antes era tudo manual... então a gente vem com as coisas daquela época lá, que era tudo manual..." S7

“(...) eu peguei essa fase... limpar tudo, tudo...” S2

“...ó, mudança de decúbito você tinha que fazer... não tinha, não: ‘ó, não dá...' você tinha que fazer... tem que levar
} 
paciente pro banho, você tinha que tirar da cama e levar pro banho." S8

Os maus hábitos vão desde empurrar uma maca sozinho e realizar transferência sem o auxílio de facilitadores a assumir posturas inadequadas ao escrever, por exemplo. Falas a respeito de transporte de paciente demonstram isso com maior clareza; todos sabem que é melhor o manuseio das macas em dupla, seja pelo mau estado de conservação da maca, seja pela formação de degraus nos elevadores; entretanto, nem sempre isso é possível, tanto por inexistência de funcionário no momento, como também por costumes inadequados previamente adquiridos.

“(...) Outra... Uma coisa gritante que eu vejo que eu até questiono que eu vejo é continuar empurrando a maca sozinho... porque eu tô cansado de ver: vai um funcionário e leva um paciente e cinco minutos depois vai outro funcionário pegar outro paciente. Por que que não? Os dois vão lá, buscam um e os dois vão lá e buscam o outro.” S8

“(...) então tem que ser sempre em duas pessoas, mas nunca tem duas pessoas para empurrar... até no meu relatório está escrito lá... que sempre que possível vai ser feito em duas pessoas... mas nunca tem..." S7

"E aí acaba virando rotina..." S8

“...e você acaba esquecendo.” S9

O atendimento grupal parece trazer percepções individuais e transformá-las em coletivas, na medida em que as falas de todos encontram território para trânsito. De acordo com Sato (1993), grupos direcionados a trabalhadores adoecidos favorecem o estabelecimento de relações do adoecimento com questões relacionadas ao trabalho, auxiliando o trabalhador na diminuição de culpabilização individual, alimentada pelo próprio indivíduo e pela sociedade.

Muitas falas convergem para a ideia de que já há mudanças bastante positivas de seus ambientes de trabalho que colaboram para uma melhor execução das tarefas de trabalho.

“(...) hoje em dia, não sei há quanto tempo você está aqui, a gente tem muito mais coisas que facilitam o trabalho, está muito mais leve..." S7

“(...) vale-refeição... né? (risos)” S5 
“(...) não tinha nada disso... então melhorou. A gente não tinha ambulância contratada." S5

Concordam também que já há um espaço de discussão para que o funcionário reflita sobre as tarefas que lhe são dadas e consiga dizer o que é cabível, o que não conseguirá realizar, dentre outros aspectos próprios do cotidiano.

“...hoje em dia você até conversa, questiona, discute e fala: 'olha não dá, o paciente é muito obeso...' mas antes nós não tínhamos isso." S8

Observamos que os sujeitos do estudo relatam alguns aspectos que podem contribuir para uma melhor QVT. Pesquisas que avaliam a QVT do pessoal de Enfermagem colocam a questão de existência de comunicação interpessoal e adequada interação da equipe como aspectos favoráveis para organização do trabalho e satisfação dos profissionais (Schmidt, Dantas, 2006; Farias, Zeituone, 2007). De maneira mais aprofundada, uma dessas pesquisas objetivou construir qualitativamente com os trabalhadores de um centro municipal de saúde do Rio de Janeiro alguns indicadores de QVT; a respeito do tema em questão, foram elencadas dimensões que se aproximam das citadas pelos trabalhadores desse estudo, como: integração da equipe, compreensão das necessidades de trabalho, bons relacionamentos interpessoais e discussões periódicas de serviços e programas (Farias, Zeitoune, 2007).

Com relação ao cuidado provido pela assistência médica, as falas concordam sobre a existência de um descaso em relação ao tratamento médico recebido, pois acreditam que na verdade há um tratamento direcionado ao alívio dos sintomas, sem que haja esforços para corrigir as prováveis causas dos quadros por eles apresentados. Muitos sentem que não recebem a devida atenção, já que sabem que têm quadros graves de difícil reversão.

"Você começa com o problema lá atrás e isso eu sei porque eu senti na pele... porque desde o início você tinha aquela dor e falava: 'ah não isso é só uma lombalgia', 'ah, toma um anti-inflamatório...' 'ah, toma não sei o quê...' e não dá continuidade... sabe... mesmo que você passe no ambulatório não dá sequência... você sente uma dor, você passa no ps... ah, não... se quiser marcar consulta aqui é só coisa de emergência... te passa um relaxante muscular e antiinflamatório... e aí passou a dor. você manda ver..." S8 


\begin{abstract}
“mas eles não dão atenção...” S3
“...algumas coisas que já foram feitas, quer dizer, não adiantou, quer dizer... tenho que conviver com isso! Então eu vou ao médico? Vou nada!... sabe... vou ao médico hoje, que eu sinto dor... hoje eu tô morrendo de dor, tô trabalhando... eu vou ao médico fazer o quê? chega lá, eu vou no médico, ele vai olhar pra minha cara e vai fazer o quê? 'Toma lá um analgésico...' vai resolver? Não!" S1

“ eu até ia falar isso... dá licença um pouquinho e vai falar... você tem que se acostumar com a dor! "S12
\end{abstract}

Nas Normas e Manuais Técnicos do eixo temático de Saúde do Trabalhador da política brasileira é expressa uma preocupação com a formação inadequada da classe geral de profissionais da saúde para lidar com casos de DORT, visto que raramente os profissionais são expostos a toda a complexidade que envolve as causas desses distúrbios. Sugerem, dessa forma, que o tratamento do paciente com DORT seja multiprofissional, já que a qualidade de seu tratamento será fundamental na sua melhora ou controle. Acredita-se, portanto, que profissionais devam ser capacitados para lidar com essa problemática e a classe médica, em especial, deveria inserir em suas avaliações indagações sobre posto e dinâmica de trabalho (Brasil, 2001b).

Também nessa questão, há concordância dos ideais dos participantes com o termo QVRS, já que o tratamento médico recebido influencia negativamente a qualidade de vida, na medida em que o principal sintoma dos DORT é o quadro álgico, que, nesse caso, está sendo totalmente menosprezado em sua essência.

Os sujeitos mencionaram a questão da preocupação com o parceiro de trabalho, seja no intuito de não querer sobrecarregá-lo, seja na intenção de fazê-lo perceber que realizar determinadas posturas erradas pode acarretar agravos à saúde. Existe uma consciência dos trabalhadores em conseguirem desempenhar seu papel para que não haja uma divisão desigual de trabalho, eliminando assim a possibilidade de saber que a limitação ou restrição de quem está doente pode levar o outro a adoecer.

As preocupações com os colegas de trabalho aparecem em várias falas, tanto no sentido de não desejar sobrecarregar o parceiro, como também já com a consciência de que ele também precisa prevenir-se de futuras (e prováveis) lesões. 
“(...)se você tem dor, você fica depressiva... e... por vários motivos... no trabalho porque você acaba acarretando o seu colega porque (...) você acaba sobrecarregando porque você é porque é pra coisas que você deveria fazer... isso no trabalho chateia bastante a gente...isso é uma coisa que não só eu, mas outras pessoas também comentam." S1

Relatam que, em muitos casos, estratégias para aconselhar pares de trabalho sobre prevenção nas tarefas diárias não são bem vistas.

Surge ainda uma questão bastante ambígua a respeito das restrições, já que nesses grupos tivemos exemplos de funcionários com e sem restrições. Aqueles com restrições preocupam-se por não desempenharem seus papéis de maneira integral e que, dessa forma, incidirão sobre outro; aqueles sem restrição sabem que são sobrecarregados e que, por isso, se expõem a um risco aumentado de agravos à saúde.

Fica evidente que a mescla entre enfermeiros, auxiliares e técnicas no grupo foi bastante positiva, pois aqueles que trabalham mais na assistência direta ao paciente conseguem perceber que enfermeiros também têm sobrecarga, porém em outros aspectos.

“(...) mas você vê que não é só na clinica, não; que no hospital todo e inclusive numa enfermeira... (falando sobre o fato de existirem funcionários com DORT)" $\mathrm{S} 1$

Ao longo do estudo, os trabalhadores começam a demonstrar uma crescente conscientização de seus organismos e do meio que os cerca. Essa conscientização é vista não só em como começam a se observar, mas também em quanto atribuem ao espaço criado nesse coletivo e como se cuidam foram desse espaço com o que ali é absorvido e elucidado.

Com o passar de algumas sessões, revelam que o espaço propiciou um local para promoção de conversas, tendo havido depósito de angústias e sofrimento por poder falar desses desabafos, e promoveu um local com uma escuta diferenciada.

\footnotetext{
"não deixa de ser qualidade de vida, pode desabafar ... Ver que você não tá sozinho,né?... tem mais gente...” S4

“... no mesmo barco...” S2
} 
Ver que os outros têm os mesmos problemas é reconfortante, na medida em que os trabalhadores percebem que não estão sós.

O fato de poder ser comparado a um colega "igual" é colocado como uma situação que favorece uma boa qualidade de vida. Conversar, desabafar, colocar questões que cabem em espaços e momentos apropriados, já que muitos reclamam que na grande maioria das vezes sentem-se chatos, repetitivos e queixosos com colegas de trabalho e familiares. Esse espaço se torna para eles extremamente salubre, pois sabem que é o espaço que os aceitará como são, sem a possibilidade de estigmatização.

\footnotetext{
“...mas eu achei o mais legal nem é ver que o outro também tem, mas é poder falar... ter um espaço para dizer onde que eu tenho a dor: 'ah, você também tem... sabe? Ter algo em comum... é uma união na dor, não sei..." S3
}

De acordo com Maximino (1995), em um processo grupal bem-sucedido, os vínculos são criados a partir da vivência de singularidades e quanto estas são significativas e pertinentes em relação aos outros. Já em discussões mais adiante no processo grupal, fica claro como esses grupos serviram de "caixa de ressonância": limitações, dores, irritações e falas vivenciadas diariamente encontram acolhimento nesse local de queixas comuns. Fica evidente o encaixe de cada um nesse local; saber que pertencem a um grupo o qual não são mais estigmatizados, diferentes ou hostilizados por se encontrarem em situações que diferem das consideradas normais.

Durante a realização de vários procedimentos práticos, como: massagem retrógrada e muscular para MMSS e relaxamento, foi visível o conforto corporal; nas conversas realizadas, já se observam mudanças de discurso no sentido de perceber: a importância da incorporação de determinadas estratégias ou determinados comportamentos no dia a dia para que haja uma diminuição da dor e suas limitações e a necessidade de realizar pequenas modificações para se adaptar a elas. Em conversas com observadores, chamou-nos a atenção a expressão facial composta por sorrisos, durante a realização de relaxamento com os olhos fechados.

As falas sobre uma maior atenção a si mostram-se cada vez mais presentes, denotando maior consciência de seus quadros e da relação de seus sintomas com 
eventos cotidianos, como pressão psíquica ou sobrecarga física, por exemplo, o que traz, consequentemente, maneiras diferentes de cuidado consigo.

\begin{abstract}
"pra mim foi muito assim, é... de autoconhecimento... quando ela se intensifica mais, por quê? como que eu estou, como que minha cabeça está? o que que eu estou atravessando naqueles dias, naquele momento... então pra mim foi muito bom essa sacada..." S2
\end{abstract}

Tal fato teve início a partir do segundo encontro, quando alguns mencionavam já se observar de maneira mais aguçada e testar pequenas modificações.

Desde a década de 1990, as atividades grupais com portadores de DORT têm tido uma utilização crescente, com objetivos de possibilitar a autonomia sobre seus sintomas e limitações, bem como para auxiliar na modificação de hábitos cotidianos agravantes (Lima, Oliveira, 1995).

Para alívio da dor, são usadas indiscriminadamente medicações, em especial os analgésicos. As falas revelam que os pacientes suportam graus leves a moderados de dor e apenas fazem uso quando a queixa álgica torna-se insuportável. Ainda, sustentam que fazem uso sem indicação médica e que têm fácil acesso à medicação.

O uso descontrolado de medicações anti-inflamatórias ou analgésicas é bastante prejudicial aos portadores de DORT, visto que só é verificada sua eficácia no início dos quadros ou em episódios de agudizações. Em se tratando de medicamentos viáveis e eficazes para casos crônicos, devido à sensibilização aumentada dos receptores de dor, são necessárias combinações terapêuticas de antiinflamatórios e medicações psicotrópicas, sendo essencial o acompanhamento médico e adição de outras terapêuticas (Brasil, 2001b).

As vivências em grupo trouxeram novas perspectivas para lidar com o quadro álgico. O uso de estratégias simples e palpáveis, como: massagens, relaxamento, existência de pausas em determinados grupos musculares e uso de calor superficial, foi recebido de maneira surpreendente e, aos poucos, os discursos revelavam tentativas de uso corriqueiro das técnicas apresentadas, no intuito de minimizar dor sem usar medicamentos.

Demonstraram-se mudanças de paradigmas, as quais inicialmente se acreditava serem apenas um medicamento capaz de aliviar sintomas. Citam situações 
em que, com a inserção de estratégias orientadas aprendidas, muitos experimentaram fazeres diferentes em seu cotidiano. Algo que era impossível conceber, como dormir sem dor ou limpar um pequeno local, já era possível com as orientações internalizadas.

“o legal é conseguir fazer... eu me senti tão feliz que parece até bobo... pra algumas pessoas... eu não sei... mas pra mim não foi... eu consegui dar uma limpada no meu armário. Aí eu fui, limpei o armário, do jeito que dava, e depois eu fiz o que você falou... (dar uma pausa, fazer uma massagem ou realizar uma atividade leve, com utilização de outros grupos musculares) (...) eu limpei do jeito que eu quis e depois eu fiquei com disposição pra fazer outras coisas... não, mas aí eu pensei bem no que ela falou... (evitar sobreposição de atividades) por isso que eu tô falando...uma coisa de cada vez... né, porque daí se eu fizer tudo que tô pensando, eu vou ficar com dor também..." S1

"O mais legal que eu achei foi quando eu estava limpando a casa; assim, eu estava limpando o banheiro, aí eu coloquei uma música de Beethoven que tinha 15 minutos... aí eu deixei ela tocar duas vezes pra dar 30 minutos, que era onde que eu ia parar... (risos dela e de S11). Quando parou e meu marido estava assistindo televisão... eu parei... aí ele: 'que que foi?' Eu falei: 'nada, só a hora da minha massagem...' (risos de todos)." S4

Alguns chegam a mencionar que obtiveram melhoras em seus quadros de dor, objetivo não almejado há muito tempo pela garantia da impossibilidade disso.

"mas eu percebi que teve algumas vezes, algumas horas que eu dormia e relaxava bem e via, ah, eu tô sem dor... eu fiquei: 'mas eu não tô mesmo, será que eu não tô mesmo?' Eu não tô acreditando que eu não estou com dor no braço..." S1

"e eu fiquei um dia sem dor pra dormir e eu já fiquei preocupada... (risos do grupo)" S1

" eu acho, e posso estar redondamente enganada, que isso (não estar com dor) tem a ver com as massagens e a água quente." S2

"não, não tenho tido dor... mas eu tenho feito bastante alongamento..." S11 
E ao contrário de um discurso inicial, no qual as falas convergiam para o sentido de infelicidade de se ver fazendo diferente, encontramos satisfação no apenas poder fazer, mesmo que de maneira adaptada.

“(...) mas é muito bom, tenta pra você ver... você vai ver como é... é diferente... é diferente... cai até a cabeça... nossa! mas tem que limpar isso, mas eu não posso (enfatiza o eu)... mas tem que limpar... então, você não, eu não vou fazer isso hoje... e depois eu vou fazer as coisinhas bem... coisas até gostosas. pôr alguma coisa no lugar sem peso, sem... conseguir fazer um atividade leve... foi isso que eu fiz..." S1

"Pra mim foi um grande toque... porque assim alguns dias eu estou na correria; que nem hoje. é um dia que eu vou chegar super tarde... então não vou fazer nada, no máximo lavar uma louça e fazer assim, uma coisinha básica, né... agora deixar tudo pra um dia só pra eu me matar pra fazer tudo e chegar no outro dia e dar plantão de 12 horas morrendo... isso não.” S2

"Pensar pela véspera de folga também, né? Ah, não, amanhã eu tô de folga, amanhã eu não quero fazer nada... quero fazer tudo hoje.. aí você vai dormir quase de madrugada pra você fazer tudo e você tá acabada..." S10

“Aí você tá arrebentada..." S1

Percebemos, através de relatos, que o grupo deixou os trabalhadores com uma atenção maior, com uma mudança no olhar para si e para o meio externo, modificando, consequentemente, o cuidado que despendem a si.

Muitos garantem que a incorporação de hábitos de saúde, ensinados no grupo, consegue auxiliá-los a uma melhor qualidade de vida.

\footnotetext{
“Ahã, eu... eu pensava assim, sabe? como você assim meio que pensa assim que você é meio mole? Aí, caramba, eu vejo o pessoal trabalhando e não tem tanta gente reclamando. Ou eu sou reclamona... ou..." S4

“...a gente ainda se culpa...” S2

“se culpa... é, eu me sentia culpada." S4

“por que, né? Por que que eu não desempenho melhor?” S2

“E vi que na verdade não é isso." S4

"pra mim, nossa, traz assim... traz tudo... qualidade de vida... autoestima... traz assim... estar bem consigo mesmo..." S9
} 
“...e saber que tem essa alternativa... e alivia realmente...” S6

Foi visível a evolução dos trabalhadores no raciocínio do processo saúdedoença de seus quadros. Aprender a entender em que momentos surge a dor, que tipo de tarefa estava sendo realizada, qual a postura adotada e que sobrecargas fisiológicas, mecânicas ou emocionais lhes eram submetidas.

"lembrei disso... tenho lembrado da força que faço quando vou segurar no ônibus... opa, tem muita força..." S7

"Eu tô... tô... tô... diminuindo o volante... não sei por que também essa mania de segurar tão forte... besteira..." S9

"é que é como ela falou, parece que você não tinha o músculo e depois percebe que ele existe, e que ele precisa de cuidado" S7

Segunda sessão: "e eu também tô com uma dor aqui na altura do ombro e só desse lado..." S7

Quinta sessão: "Lembra que você falou assim: 'você tem essa dor no ombro, mas por quê?' Aí, eu vi.. eu ficava muito tempo com o mouse... agora não; saio, dou umas voltas, alongo..." S7

"porque eu fui pintar a casa nas férias e doeu o braço... aí eu fiz água quente e morna... e foi legal..." S6

A percepção desses aspectos fez com que houvesse incrementos em como se cuidam, tanto para que a dor não surgisse quanto para que não piorasse.

Os sujeitos foram instrumentalizados e, dessa forma, já foi perceptível verificar mudanças atitudinais. As mudanças que refletiram em adaptações no dia a dia, inseridas através das técnicas apresentadas para a diminuição da dor, foram efetuadas pelos sujeitos, que, ao serem questionados se estavam realizando o que era orientado, todos diziam que estavam e, na maioria das vezes, a amenização do quadro álgico era alcançada.

"Eu tô adaptando tudo... alongamento, exercícios, a massagem... os exercícios anteriores que aprendi com a Fabi...tô melhorando bastante... lá na sala, quando tá calmo, as cirurgias, e sento e faço..." S9 
"quando tem um direcionamento... você começa a fazer porque você não quer sentir de novo... igual ela tava falando, não, não quero sentir, vou me condicionar... vou ficar mais tempo no banho com água quente..." S10

"mas é legal também você ter um controle disso em casa, como fazer isso em casa... não precisa esperar a quinta para a fisioterapia, pode sentar no sofá e fazer massagem, pode usar o calor..." S10

"e incorporar isso..." S2

"dá uma diferença, parece que você fica mais descansada quando você termina o banho... muito bom... e legal... e quando eu massageio, essa musculatura aqui dos braços dói bastante, mas depois tranquilo..." S7

“(...) coisas que a gente gosta que às vezes é o simples ficar deitado no sofá com filme, pensando no nada, e que isso faz muito bem pra gente e que a gente tem que tentar fazer isso todos os dias, nem que for um pouquinho, alguma coisa que nos atraia...." S2

As falas revelam que estamos em consonância com os objetivos do tratamento direcionado aos portadores de DORT preconizados, já que contemplamos elementos para: compreender as causas dos sintomas osteomusculares e possíveis repercussões, propiciar manifestação de sentimentos, facilitar a realização das atividades de vida diária com parcimônia e disciplina, sobretudo no uso de regiões acometidas, melhorar a percepção corporal, ensinar a lidar com a dor crônica com alternativas aos medicamentos e identificar fatores causais e de piora (Settimi et al., 1998; Brasil, 2001b). Dessa forma, os sujeitos exercem papel ativo no manejo dos DORT, maximizando seus conhecimentos e comportamentos.

As discussões fomentadas em ambiente coletivo podem possibilitar a descoberta e o percurso em fatores e experiências muitas vezes invisíveis aos profissionais de saúde, que reduzem o tratamento dos DORT em clínico e cirúrgico. Ao ampliarmos o espectro de tratamento, conseguimos englobar alguns dos objetivos da Promoção da Saúde, a qual passa a ocorrer quando são disponibilizadas, por exemplo, boas condições de saúde física e formas de lazer e descanso.

Houve, também, questionamentos quanto aos prognósticos, porém com uma certa leveza nas expectativas e nas reflexões realizadas. A percepção que passam é 
que compreendem que devem, de fato, obedecer os limites de seus organismos e adaptar suas tarefas às suas reais capacidades.

Podemos concluir que o grupo possibilitou um pensar diferente sobre os seus quadros: enquanto a ideia inicial era ter e conviver com a dor, as falas finais remetem a novas esperanças; imaginar-se fazendo um esporte, podendo pensar em novos horizontes, modificou o discurso desses pacientes, que em encontros finais puderam demonstrar sensações de grande expectativa com o cuidado de sua saúde, de seu bem-estar e não necessariamente de eliminar sua dor ou de suportar um agravo de longa data.

Alguns pacientes já iniciam a multiplicação do que foi aprendido nos grupos em seus setores, levando aos outros a possibilidade de, também, conseguirem amenizações em suas queixas e a possibilidade de cuidados diferenciados. Relatam que aqueles que, porventura, não puderam participar mostram-se extremamente interessados no conteúdo dos grupos e solicitam aos participantes a divisão dos conhecimentos adquiridos.

\footnotetext{
“(...) e passar pras outras pessoas também... que lá na clínica teve gente que não teve a oportunidade de fazer isso que a gente está fazendo... mas eu passei isso pra algumas pessoas, é?" S5

“...porque outro dia, na UTI, tem a bolinha de tênis e eu fico lá... ando com a bolinha na bolsa e todo mundo quer... esses dias minha chefe chegou lá e falou: 'que você está fazendo?' 'Ô, chefe, tô tentando diminuir o número de absenteísmo... vamos fazendo uma massagem...' Chefe: 'acho ótimo...' 'então compre bolinhas pra gente...' Chefe: 'vou pensar'... então, um faz no outro, a gente vai melhorando..." S10

"Eu criei o kit massagem do berçário... ensinei lá as meninas... deixei os rolos de papel... então, primeiro eu fiz na 'chefa' pra ela sentir, pra ver se podia montar o kit ou não... daí ela gostou e falou que podia montar lá... então, quem quer vai lá na gaveta e pega tal, e estão gostando bastante..." S7
}

Potenciais criativos são evocados e surgem ideias de uso de materiais existentes nos próprios setores e atividades que poderiam ser instauradas no cotidiano da instituição sem o prejuízo das funções laborativas das equipes.

A cada situação-problema compartilhada ocorreu uma análise coletiva de possíveis alternativas, sempre baseadas em vivências individuais. Coletivizadas e, 
não obstante, multiplicadas pelo ambiente da instituição, carregam um potencial de transformação social.

Foram observadas algumas limitações em seguir as orientações propostas, especialmente ao olharmos para determinados postos de trabalho e limitações do próprio serviço: saber que alguns setores têm uma dinâmica diferenciada e saber, também, que em alguns períodos (de plantão ou de limpezas terminais) haverá, sim, uma sobrecarga de trabalho, mas que poderá ser amenizada lançando mão das orientações obtidas no grupo.

São reveladas, em ambos os grupos, as disparidades existentes entre diferentes ambientes da instituição em questão, em especial as diferenças do cotidiano do pronto-socorro adulto. Quando comparado a outros ambientes, surgem diferenças importantes com relação ao imediatismo na realização de algumas tarefas, como transferências - o que muitas vezes leva a transferências sem auxílio e ergonomicamente inadequadas, à inexistência de equipamentos para mudanças posturais, aos quadros de determinados pacientes que exigem contensão para tratamento, a sazonalidade, indicando que há uma heterogeneidade no número de atendimentos/dia e a impossibilidade de programação de tarefas cotidianas devido à imprevisibilidade do local.

“(...) (no pronto-socorro) sempre sobrecarregados... não, dá, assim... se eu estou escalada, assim, eu tô comprovando a cada semana, se estou escalada, acredito que a S3 também, na sala de medicação, preparo a gente não tem tempo, nem lembra que tem braço, só lembra que dói..." S2

"...equipamento zero; acho que os piores equipamentos estão com a gente." S2

"Acho que essas orientações são válidas, mas no PS não dá pra programar; mas na hora da correria, na hora que você tá... é a última coisa que você vai pensar... a não ser que naquele momento realmente você esteja com dor ou alguma coisa está te impedindo de.. aí você lembra de fazer uma posição diferente." S10

“...tem dias, como já foi falado anteriormente, que a gente fica seis horas ou 12 horas no preparo de medicação, tá? Então, não paro, é muito difícil ter tempo pra parar ou parei correndo e fui fazer xixi... voltei, fui tomar uma água... mas assim, em casa... sabe que tá pegando legal porque começa a doer, né? durante o dia e a noite, a hora 
que relaxou... aí vamos lá (tomar banho, massagem, lazer, ela quis dizer nesse sentido)... já ameniza." S2

Tais situações são citadas como fontes de estresse emocional e risco ergonômico, bem como dificultadoras da inserção de estratégias propostas em grupo - pausas, massagens e alternância de atividades.

Os trabalhadores concordam que a situação é agravada quando o cumprimento da jornada é feito na sala de preparo de medicações, onde é rara a ocorrência de pausas e são corriqueiros os movimentos repetitivos e a postura em pé. Dessa forma, entende-se que o pronto-socorro é um ambiente extremamente particular e que mereceria estudos específicos e individualizados, a exemplo do realizado por Loiola e Felli (2007).

Os participantes deixaram evidentes algumas das causas de insatisfação no trabalho e de como se sentem desamparados em algumas ocasiões.

Existe um discurso coletivo que traz a expectativa dos trabalhadores com relação ao papel de instituição, que deveria colocar-se como um estimulador da promoção da saúde de seus funcionários. Existe uma grande esperança desses funcionários que os responsáveis pelo seu local de trabalho também cuidem da saúde daqueles que lá prestam serviço, disponibilizando espaços permanentes para descanso ou atividades de promoção de saúde, facilitando a divulgação de projetos relacionados à saúde.

Outros sugerem que seria importante chamar a atenção da equipe de Enfermagem para a problemática dos DORT, utilizando recursos como: painéis espalhados pelo hospital, palestras e grupo de estudo direcionado a compreender e sanar problemas correlatos, ainda que existam profissionais que possam estar nos setores realizando trabalhos com funcionários no horário de trabalho e que possam opinar sobre a compra de novos equipamentos ou sobre eventuais reformas estruturais que venham a ocorrer.

Algo semelhante foi elaborado por Martins (2011) que, após estudo realizado com trabalhadores com sintomas osteomusculares de uma UTI, criou um manual ilustrado com orientações posturais durante as principais atividades de trabalho da enfermagem, onde as situações-risco foram enumeradas pelos próprios trabalhadores. 
Através dessa sugestão, percebe-se uma iniciativa de dar conta dos fatores psicossociais precipitadores ou causadores dos DORT, dirigindo a atenção não só aos sintomas físicos, mas às outras situações-risco que podem levar à ocorrência ou piora deles.

O uso de grupos focais para construção de alternativas para melhoria da qualidade de vida pode constituir uma estratégia eficaz no tratamento complementar dos DORT, assim como proposto por diversos autores (Hoefel et al., 2004; Merlo, Jacques, Hoefel, 2001). A inovação deste trabalho reside no fato de ter aglutinado portadores de DORT com ambientes diversos e cargas e demandas diferentes e de termos tido a possibilidade de oferecer estratégias que transcendem o modelo de assistência biomédico, centrado na doença como fenômeno individual (Buss, 2000).

A análise das categorias e temas permite evidenciar que a dor e as situações desfavoráveis no trabalho criam agravos à QV e que alguns fatores da vida dos trabalhadores - como ausência de atividades de lazer, período prolongado na função , jornada de trabalho intensa e com desorganização do processo de trabalho e realização de atividades domésticas, podem também contribuir negativamente para a QV.

Entretanto, estratégias para inserção de bons hábitos de saúde e vida no geral, com enfoque sobre a minimização de sintomas, inserção de atividades de lazer, adaptação às limitações e controle de posturas e posicionamentos no trabalho, parece trazer de benefícios aos trabalhadores. 


\section{CONCLUSÕES}

O estudo de caráter exploratório-descritivo de abordagem qualitativa teve como objetivos apreender a qualidade de vida de trabalhadores de enfermagem acometidos por DORT e construir possíveis estratégias para a melhoria da mesma.

Foi desenvolvido tendo como população os trabalhadores de enfermagem de um hospital público universitário, constituído por 11 mulheres e dois homens, portadores de DORT em membros superiores. Os sujeitos foram representativos de todas as categorias de enfermagem, assim como de diversas unidades assistenciais.

Os dados foram coletados em dois momentos. $\mathrm{O}$ primeiro momento referiu-se aos dados sócio-demográficos, captados por meio de entrevista individual; e o segundo, aos dados coletados com a técnica de grupo focal, relativos ao impacto dos DORT na qualidade de vida desses trabalhadores e à construção de alternativas para manejo desses distúrbios, dentro do referencial de Promoção da Saúde.

A análise dos dados, também, foi realizada em dois momentos.

A análise dos dados sócio demográficos permitiu evidenciar que:

- A maioria das sintomatologias refere-se a quadros em ombros, o que acaba prejudicando a realização de atividades simples e cotidianas. Além do sintoma dor - o de maior expressividade, devido à cronicidade dos quadros e da continuidade de exposição às condições inadequadas de trabalho, foram verificadas diversas modificações no cotidiano, como alterações de humor, lentidão e diminuição na realização de atividades, inclusive de auto-cuidado.

- A média de tempo de trabalho nesta instituição é de 19 anos, denotando extensa exposição a cargas fisiológicas, com predominância de atividades manuais, exigindo, sobretudo, maior aplicação de força, aumentando o risco de sobrecargas osteomusculares. Não obstante, sendo a maioria composta por trabalhadores do sexo feminino, somadas às penosas atividades de trabalho, estão os afazeres domésticos, realizados integralmente por sete trabalhadores e parcialmente, por cinco deles. Enquanto 
atividades extra-profissionais, são citadas como meramente ocasionais e não-habituais, experimentações em atividades de lazer.

- O veículo de transporte de escolha principal de 10 trabalhadores é o carro, com um tempo médio de deslocamento de 30 minutos.

Dessa forma, observamos no cotidiano desses trabalhadores, uma grande quantidade de situações adversas ao quadro dos DORT e muito poucas estratégias que amenizariam os sintomas, colaborando para a perpetuação dos quadros e, em longo prazo, aumento de limitações.

Em um segundo momento, a análise dos dados do grupo focal pela análise temática possibilitou a apreensão de quatro categorias: existindo com dor, QV é não ter limitações, meu trabalho influenciando na minha QV e cuidando e sendo cuidado

Na primeira categoria - "existindo com dor" - as falas versaram a respeito das histórias de vidas, expressas com grande influência do diagnóstico, a dor enquanto mediadora das expectativas de estar no grupo e correlações entre dor e desequilíbrio emocional ou estresse.

A análise da segunda categoria - "QV é não ter limitações" - evidencia, inicialmente, que os trabalhadores a definem como um estado de equilíbrio entre várias esferas da vida. Entretanto, as falas mostram que a QV encontra-se prejudicada pela co-existência de dois aspectos. $\mathrm{O}$ primeiro relacionado às limitações no fazer cotidiano, predominantemente representadas pela dor, uma vez que essa gera privações e incapacidades, obrigando esses trabalhadores a modificarem as formas de se relacionar com objetos e pessoas. O segundo aspecto diz respeito aos enfrentamentos cotidianos no ambiente de trabalho, tema emergente da terceira categoria.

Na terceira categoria - "Meu trabalho influenciando na minha QV" - são citados diversos fatores no cotidiano de trabalho que podem influenciar negativamente a qualidade de vida: excesso de tempo no local de trabalho, inadequação de equipamentos e organização e processos de trabalho inapropriados; tais situações desfavoráveis geram um tamanho desgaste físico e emocional, que parece drenar a energia para realizar atividades protetoras que trariam benefícios à qualidade de vida.

Dessa forma, as falas dialogam com as definições de QVRS e QVT, já que a dor media e pondera os padrões de vida desses trabalhadores e a atribuição do valor 
à vida sofre forte influência desse sintoma. Além disso, provou-se que inadequações no processo de trabalho alteram significativamente a QV.

A análise dessa categoria permite concluir que a QV desses profissionais encontra-se intimamente relacionada com a existência de dor e de dificuldades no processo de trabalho. Ressaltamos que a combinação desses dois fatores é que parece levar a uma qualidade de vida diminuída, expressa principalmente pela ausência de disposição para engajamento em outras atividades. Ter dor e exercer funções laborais em condições consideradas inadequadas, geram desgastes que impedem ter uma boa QV, o que permite sintetizar que para a melhoria da qualidade de vida, faz-se necessária a proposta de uma estratégia que englobe esses dois aspectos.

Na quarta e última categoria - "Cuidando e sendo cuidado" - apreendeu-se temas como dificuldades na promoção da própria saúde, que apontam cristalização de comportamentos que dificultam a adoção de hábitos de saúde e bem-estar. Enquanto estratégias institucionais que enfocam o cuidado aos profissionais, foram apontados alguns aspectos favoráveis do ambiente de trabalho, como comunicação para compreensão das necessidades e reuniões periódicas. Entretanto, os trabalhadores ainda consideram insuficientes as medidas coletivas existentes.

Notadamente, foram referidas as insatisfações com atendimentos de saúde, que reproduzem o modelo biomédico vigente, sem atentar à complexidade dos fatores causais de DORT.

As falas revelam que há preocupações com colegas de trabalho, tanto no sentido de orientar quanto aos riscos de DORT, quanto na possibilidade de ensinar estratégias aprendidas no grupo. Não raro, alguns dos trabalhadores inseridos nesse estudo, iniciaram a reprodução das técnicas e orientações aprendidas em seus setores, comunicando chefias e pares de trabalho e criando formas de manutenção do cuidado aprendido, como compras de equipamentos de baixo custo e montagem de kits.

Verificou-se satisfação com o processo grupal, com crescente conscientização e mudanças no cuidado. Em especial, foram despertadas ações cruciais para compreensão e controle de quadros crônicos de DORT: a atenção a si e às múltiplas combinações de fatores pessoais, físicos, sociais e emocionais e a observação do meio, com seus riscos e benefícios possíveis. Perceber a relação do corpo com o entorno passou a promover maior controle de pioras e possibilitou a adoção de estratégias que pudessem trazer benefícios à saúde. Essa instrumentalização 
promoveu mudanças atitudinais, refletidas em adaptações no dia-a-dia para inserir as técnicas ensinadas, como: pausas, modificações posturais, divisão de atividades e uso de calor superficial.

As vivências em grupo trouxeram novas perspectivas para lidar com a dor. Foi possível construir junto aos trabalhadores um programa educativo onde foram oferecidas novas perspectivas para amenização de sintomas, bem como de modificações comportamentais relacionadas a componentes posturais e ambientais, indo ao encontro de um dos princípios de Promoção da Saúde e abordando um dos pilares da QV para esses trabalhadores de Enfermagem.

Não obstante, foi também percebido, despertado ou aguçado, que são necessárias ações coletivas para criar e manter condições favoráveis ao desenvolvimento da saúde, sejam elas de responsabilidade da própria instituição de trabalho ou de aparelhos sociais próximos do local de trabalho. Os trabalhadores foram sensibilizados quanto à reflexão e uso de habilidades para atuar na melhoria de sua qualidade vida, onde compreenderam que há a necessidade de sua própria responsabilização, bem como do sistema de saúde e da comunidade, combinando estratégias multissetoriais enquanto origem das propostas mais promissoras de qualidade de vida.

Foram bastante enfatizadas as expectativas relacionadas às responsabilidades institucionais frente aos seus funcionários, uma vez que também o ambiente de trabalho é responsável pela saúde e bem-estar. Percebe-se uma iniciativa de contemplar os fatores psicossociais precipitadores ou causadores dos DORT, dirigindo a atenção não só aos sintomas físicos, mas às situações-risco que podem levar à ocorrência ou piora dos mesmos.

As falas transitam por um espaço de ressignificação do cotidiano e fortalecimento no controle dos quadros, com necessidade de inserção crescente de estratégias de saúde, bem-estar e consequente minimização da dor no dia-a-dia.

Para lidar com a complexidade do tema 'qualidade de vida' nos trabalhadores de enfermagem, evidencia-se que também deve haver mudanças na organização dos seus processos de trabalho.

Este estudo possui algumas limitações. De acordo com as disponibilidades da pesquisadora, de espaço para realização do estudo e, também, pelo interesse daqueles que se submeteram à pesquisa, foi possível apenas contemplar funcionários do turno 
diurno. Não desconsideramos que, diferenças de processos de trabalho entre turnos e questões como avaliação de trabalhadores que trabalham em esquema de plantões noturnos existem e poderiam gerar outros dados valiosos para esse tipo de estudo.

Também relacionado ao espaço para a coleta de dados, essa proposta não pode contemplar o ambiente e o processo de trabalho, que carregam elementos notadamente relevantes na abordagem da qualidade de vida na população avaliada. 


\section{REFERÊNCIAS}

Alexandre NMC, Rogante MM. Movimentação e transferência de pacientes: aspectos posturais e ergonômicos. Rev Esc Enferm USP. 2000; 34(2): 165- 73.

Almeida PJS, Pires DEP. O trabalho em emergência: entre o prazer e o sofrimento. Revista Eletrônica de Enfermagem. 2007; 9(3): 617-629. Disponível em: http://www.fen.ufg.br/revista/v9/n3/pdf/v9n3a05.pdf

Antunes RLC. Adeus ao trabalho? Ensaio sobre as metamorfoses e a centralidade do mundo do trabalho. Rio de Janeiro: Cortez, 2008, 212 p.

American Occupational Therapy Association - AOTA. Occupational therapy practice framework: domain and process. Am J Occup Ther. 2008; 62(6): 625-683.

Araújo GA, Soares MJGO, Henriques MERM. Qualidade de vida: percepção de enfermeiros numa abordagem qualitativa. Rev Eletr Enferm [Internet]. 2009 [citado 2012 mar.13];11(3):635-41.

http://www.fen.ufg.br/revista/v11/n3/pdf/v11n3a22.pdf

Disponível:

Auquier P, Simeoni MC, Mendizabal, H. Approches théoriques et méthodologiques de la qualité de vie liée à la santé. Revue Prevenir.1997; 33:77-86.

Bongers PM, Kremer AM, ter Laak J. Are psychosocial factors, risk factors for symptoms and signs of the shoulder, elbow, or hand/wrist?: a review of the epidemiological literature. Am J Ind Med. 2002; 41: 315-342.

Bongers PM, Ijmker S, Van Der Heuvel SVD, Blatter BM. Epidemiology of work related neck and upper limb problems: psychological and personal risk factors (part I) and effective interventions from a bio behavioural perspective (part II). J Occup Rehabil 2006; 16 (3): 279-302.

Borges CD, Santos MA. Aplicações da técnica de grupo focal: fundamentos metodológicos, potencialidades e limites. Rev SPAGESP. 2005; 6(1): 74-80. 
Brasil. Ministério da Saúde. Organização Pan-Americana da Saúde no Brasil. Doenças relacionadas ao trabalho: manual de procedimentos para os serviços de saúde. Organizado por Elizabeth Costa Dias. Brasília: Ministério da Saúde do Brasil; 2001a.

Brasil. Ministério da Saúde. Departamento de ações pragmáticas estratégicas. Área técnica de saúde do trabalhador. Diagnóstico, tratamento, reabilitação, prevenção e fisiopatologia dos LER/DORT. Brasília; 2001b.

Brasil. Ministério da Previdência Social. Instrução Normativa n. 98, de 5 de dezembro de 2003. Aprova Norma Técnica sobre Lesões por Esforços RepetitivosLER ou Distúrbios Osteomusculares Relacionados ao Trabalho-DORT [Internet]. Brasília; 2003 [citado 2012 mar. 17]. Disponível em: http://www81.dataprev.gov.br/sislex/paginas/38/inss-dc/2003/98.htm

Brasil. Ministério da Saúde. Política Nacional de Promoção da Saúde. Brasília, 2004.

Brasil. Ministério da previdência Social. [homepage na Internet]. [Atualizada em 2010 Set 12; acesso em 2010 Oct 1]. Disponível em: http://www.previdenciasocial.gov.br/conteudoDinamico.php?id=850

Brasil. Ministério da previdência Social. Boletim estatístico da previdência Social Agosto de 2010 [homepage na Internet]. [Atualizada em 2010 Aug 08; acesso em 2010 Oct 1]. Disponível em: http://www.previdenciasocial.gov.br/conteudoDinamico.php?id=482

Buss PM. Promoção da saúde e qualidade de vida. Ciênc Saúde Coletiva. 2000;5(1):163-77.

Campos JF, David, HMSL. Abordagens e mensuração da qualidade de vida no trabalho de enfermagem: produção científica. Rev Enferm UERJ. 2007;15(4):584-9.

Carvalho AJFP, Alexandre NMC. Qualidade de vida e sintomas osteomusculares relacionados ao trabalho em professores do ensino fundamental. Fisioter Bras. 2006; $7(4): 279-84$. 
Cecagno D, Gallo CMC, Cecagno S, Siqueira HCH. Qualidade de vida e o trabalho sob a ótica do enfermeiro. In: Anais do $55^{\circ}$ Congresso Brasileiro de Enfermagem; 2003 nov; Rio de Janeiro; Brasil. Rio de Janeiro: Associação Brasileira de Enfermagem; 2003. p.1-13.

Cederlund R, Iwarsson S, Lundborg G. Quality of life in Swedish workers exposed to hand-arm vibration. Occup Ther Int. 2007;14(3):156-69.

Celia RCRS, Alexandre, NMC. Distúrbios osteomusculares e qualidade de vida em trabalhadores envolvidos com transportes de pacientes. Rev. Brás. Enferm, Brasília, 2003, set/out; 56(5): 494-498.

Coggon D. Occupational medicine at a turning point. Occup Environ med. 2005; 6(2): 281-293.

Dall'Agnol CM, Trench MH. Grupos focais como estratégia metodológica em pesquisas na Enfermagem. Rev Gaúcha Enferm. 1999; 20(1):5-25.

Debus M. Manual para excelencia en la investigacion mediante grupos focales. Washington: Academy for Educational Development; 1997.

Dembe EA. The social consequences of occupational injuries and illnesses. Am J Ind Med. 2002;40:403-17.

Dias EC. A organização da atenção à saúde do trabalhador. In: Ferreira Filho M (org.). Saúdo no rabalho. São Paulo: Rocca, 2000.

Dimenãs ES et al. Defining quality of life in medicine. Scand J Health care 1990; Suppll 1:7S-10S. 
Dorcas EB et al. Measuring Health in injured workers: a cross-sectional comparison of five generic health status instruments in workers with musculoskeletal injuries. Am J Ind Med 1996; 29: 618-631.

Elfering A, Grebner S, Gerber H, Semmer NK. Workplace observation of work stressors, catecolamines and musculoskeletal pain among male employees. Scand J Work Environm Health. 2008;34(5):337-44.

Farias SNP, Zeitoune RCG. Qualidade de vida no trabalho de Enfermagem. Esc Anna Nery Rev Enferm. 2007;11(3):487-93.

Farquhar M. Definitions of quality of life: a taxonomy. J Adv Nurs. 1995;22(3):5029.

Felli VEA, Tronchin DMR. A Qualidade de Vida No Trabalho e a Saúde do Trabalhador de Enfermagem. In: Paulina Kurcgant. (Org.). Gerenciamento em Enfermagem. Rio de Janeiro: Guanabara Koogan, 2005, v. 1, p. 89-107.

Felli VEA, Mininel VA, Sarquis LMM, Bernardino E, Cruz EBSL. Monitoramento da saúde do trabalhador de enfermagem: promovendo a qualidade de vida no trabalho. In: Anais do $14^{\circ}$ Seminário Nacional de Pesquisa em Enfermagem; 2007; Florianópolis (SC), Brasil [CD-ROM]. Florianópolis: ABEn-Seção-SC; 2007.

Feng CK, Cheng ML, Mao IF. Prevalence of and risk factors for different measures of low back pain among female nursing aides in Taiwanese nursing homes. BMC Musculoskelet Disord [Internet]. 2007 [cited 2010 Oct 16];8:52. Available from: www.biomedcentral.com/1471-274/8/52

Ferrari AL. Adaptação transcultural do questionário "Cultural study of musculoskeletal and other symptoms and associated disability" - cupid questionnaire. [dissertação]. São Paulo: Escola de Enfermagem, Universidade de São Paulo; 2009.

Ferrigno ISV. Terapia da mão: fundamentos para a prática clínica. São Paulo: Santos; 2007. 
Fleck MPA, Leal OF, Louzada S, Xavieir M, Chachamovich E, Vieira G, et al. Desenvolvimento da versão em português do instrumento de avaliação de qualidade de vida da OMS (WHOQOL-100). Rev Bras Psiquiatr. 1999;21(1):19-28.

Fogaça MC, Carvalho WB, Nogueira-Martins LA. Estudo preliminar sobre a qualidade de vida de médicos e enfermeiros intensivistas pediátricos e neonatais. Rev Esc Enferm USP. 2010;44(3):708-12.

Franco GP, Barros ALBL, Nogueira-Martins LA. Qualidade de vida e sintomas depressivos em residentes de enfermagem. Rev Latino Am Enferm. 2005;13(2):13944 .

Freitas JRS, Lunardi Filho WD, Lunardi VL, Freitas KSS. Distúrbios osteomusculares relacionados ao trabalho em profissionais de enfermagem de um hospital universitário. Rev Eletr Enferm [Internet]. 2009 [citado 2010 out. 16];11(4):904-11. Disponível em: http://www.fen.ufg.br/revista/v11/n4/pdf/v11n4a16.pdf

Fugulin FMT, Gaidzinski RR, Kurcgant P. Ausências previstas e não previstas da equipe de enfermagem das unidades de internação do HU-USP. Rev Esc Enferm USP. 2003;37(4):109-17.

Ghisleni AP, Merlo ARC. Trabalhador contemporâneo e patologias por hipersolicitação. Psicol Reflex Crit. 2005;18(2):171-6.

Gianchello AL. Health outcomes research in Hispanics/Latinos. J Med Syst. 1996; 21(5):235-54. 
Gomes AL. Emergência: planejamento e organização da unidade assistência de enfermagem. São Paulo: Pedagógica/Universitária; 1994.

Gropelli TM. Nurses' and therapists' experiences with occupational musculoskeletal injuries. AAOHN J. 2010;58(4):159-66.

Gurgueira GP, Alexandre NMC, Corrêa Filho HR. Prevalência de sintomas musculoesqueléticos em trabalhadores de enfermagem. Rev Latino Am Enferm. 2003;11(5):608-13.

Gurgueira GP. Contribuições ao estudo de qualidade de vida e de restrições de trabalho em uma instituição hospitalar [dissertação]. Campinas: Faculdade de Ciências Médicas, Universidade Estadual de Campinas; 2005.

Gutterres CMF, Barfknecht KS. Terapia ocupacional nas LER/DORT. Bol Saúde. 2005;19(1):85-90.

Hales TR, Bernard BP. Epidemiology of work-related musculoskeletal disorders. Orthop Clin North Am. 1996; 27(4): 679-709.

Health Canada. Economic burden of illness in Canada [Internet]. Ottawa (ON); 2002 [cited 2012 Feb 12]. Available from: http://www.hc-sc.gc.ca

Hoefel MG, Jacques MG, Amazarray MR, Mendes JMR, Netz JA. Uma proposta em Saúde do Trabalhador com portadores LER/DORT: grupos de ação solidária. Cad Psico Soc Trab. 2004; 7: 31-9. 
Joling CI, Blatter BM, Ybema JF, Bongers PM. Can favorable psychosocial work conditions and high work dedication protect against the occurrence of work-related musculoskeletal disorders? Scand J Work Environ Health. 2008 Oct;34(5):345-55.

Kimura M, Santos VLCG, Amendola F, Salvatti MG, Gonzaga STG, Sallimbeni T. Validação do questionário de avaliação de qualidade de vida Medical Outcomes Study 36- Item Short Form Health Survey (SF-36) para a população geral da cidade de São Paulo. In: Resumos do $1^{\circ}$ Encontro Internacional de Pesquisa em Enfermagem; 2002, Águas de Lindóia (SP), Brasil. São Paulo: EEUSP; 2002. p.193.

Leite PC, Silva A, Merighi, MAB. A mulher trabalhadora de enfermagem e os Distúrbios Osteomusculares Relacionados ao Trabalho. Revista da Escola de Enfermagem da USP (Impresso). 2007; 41: 287-291.

Leite PC, Merighi, MAB, Silva, A. O cotidiano de trabalhadoras de enfermagem acometidas por DORT sob a luz da fenomenologia heideggeriana. Online Brazilian Journal of Nursing. 2007; 6: 1-10.

Lima A, Oliveira F. Abordagem psicossocial da LER: Ideologia da culpabilização e grupos de qualidade de vida. Em W. Codo \& M. C. Almeida (Orgs.),1995, Petrópolis,Ed. Vozes, p136-159.

Lipscomb J, Trinkoff A, Brady B, Geiger-Brown J. Health care system changes and reported musculoskeletal disorders among registered nurses. Am J Pub Health. 2004; 94(8): 1431-1435.

Logan HL. Contributors to dentists' job satisfaction and quality of life. Journal of the American College of Dentists. 1997. p39-43.

Loiola RA, Felli VEA . Musculoskeletal disorders among nursing workers and the quality of life. Ergonomia: An International Journal of Ergonomics and Human Factors. 2007; 29: 251-6.

Magnago TSBS, Lisboa MTL, Souza IEO, Moreira MC. Distúrbios músculo esqueléticos em trabalhadores de enfermagem: associação com condições de trabalho. Rev Bras Enferm. 2007;60(6):701-5. 
Marcelino NC. Lazer e Educação - 2ª edição. Campinas, São Paulo: Papirus; 1990.

Martarello NA. Qualidade de vida e sintomas osteomusculares em trabalhadores de higiena e limpeza hospitalar [dissertação]. Campinas: Faculdade de Ciências Médicas, Universidade Estadual de Campinas; 2005.

Martins, AC. Sintomas osteomusculares relacionados ao trabalho de Enfermagem em unidade de Terapia Intensiva [dissertação]. São Paulo: Escola de Enfermagem, Universidade de São Paulo; 2011.

Marziale MHP, Carvalho EC. Condições ergonômicas do trabalho da equipe de enfermagem em unidade de internação de cardiologia. Rev Latino Am Enferm. 1998; 6(1):99-117.

Maximino VS. A constituição de grupos de atividade com pacientes graves. Rev. Centro Estudos Ter. Ocup. 1995; 11(1).

McPhee CS, Lipscomb HJ. Upper-extremity musculoskeletal symptoms and physical health related quality of life among women employed in poultry processing and other low -wage jobs in Northeastern North Carolina. Am J Ind Med. 2009;52(4):331-40.

Mergener, CR, Kehrig, RT, Traebert, J. Sintomatologia músculo-esquelética relacionada ao trabalho e sua relação com qualidade de vida em bancários do Meio Oeste Catarinense. Saúde Soc. 2008;1(4):171-81.

Merlo ARC, Jacques MGC, Hoefel MGL. Trabalho de Grupo com portadores de Ler/Dort: relato de experiência. Psicol Reflex Crít. 2001;14(1):253-58.

Michelin, CF, Loureiro, CA. Estudo epidemiológico dos distúrbios musculoesqueletais e ergonômicos em cirurgiões-dentistas. Rev Fac Odontol Univ Passo Fundo. 2000; 5(2):61-7.

Michlovitz SL, Nolan TP. Modalities for therapeutic intervention. Philadelphia: F.A. Davis Company, 2005. 
Minayo MCS. O desafio do conhecimento: pesquisa qualitativa em saúde. São Paulo: Hucitec, 2008.

Minayo MC, Hartz ZMA Buss PM. Qualidade de vida e saúde: um debate necessário Ciênc Saúde Coletiva. 2000;5(1):7-18.

Minayo-Gomez C, Thedim-Costa SMF. A construção do campo da saúde do trabalhador: percurso e dilemas. Cad Saúde Pública. 1997;13(2):21-32.

Mitchell L. Simple Relaxation: The Mitchell method for easing tension. London, Butler and Tanner, Frome and London, 1977.

Morris J, Perez D, McNoe B. The use of quality of life data in clinical practice. Qual Life Res.1998;7(1):85-91.

Moser ADL, Kehrig R. O conceito de saúde e seus desdobramentos nas várias formas de atenção à saúde do trabalhador. Fisioter Movim. 2006;19(4):89-97.

Muggleton JM, Allen R, Chappell PH. Hand and arm injuries associated with repetitive manual work in industry: a review of disorders, risk factors and preventive measures. Ergonomics. 1999;42(5):714-39.

Murofuse MT, Marziale MHP. Mudanças no trabalho e na vida de bancários portadores de Lesões por esforços repetitivos: LER. Rev Latino Am Enferm. 2001; 9(4):19-25.

Murofuse MT, Marziale MHP. Doenças do sistema osteomuscular em trabalhadores de enfermagem. Rev Latino Am Enferm. 2005;13(3):364-73. 
Myiamoto ST. Fisioterapia preventiva atuando na ergonomia e no stress no trabalho. Rev Fisioter Univ São Paulo. 1999; 6(1):83-91.

Oler FG, Jesus AF, Barbosa DB, Domingos, NAM. Qualidade de vida da equipe de enfermagem do centro cirúrgico. Arq Ciênc Saúde. 2005;12(2):102-10.

Oliveira LCC. Doença invisível, medicina ambígua: a configuração clínica da LER/DORT [tese doutorado]. Salvador: Universidade Federal da Bahia; 2006.

Organização Mundial de Saúde (OMS). Década do Osso e da Articulação: movimento articular, 2000/2010 [Internet]. [citado 2010 out. 22] Disponível em: http://www.reumatorj.com.br/decada.htm

Ong BN, Hooper H, Jinks C, Dunn K, Croft P. 'I suppose that depends on how I was feeling at the time': perspectives on questionnaires measuring quality of life and musculoskeletal pain. J Health Serv Res Policy. 2006;11(1):81-8.

Paschoa S, Zanei SSV, Whitaker IY. Qualidade de vida dos trabalhadores de enfermagem de Unidades de Terapia Intensiva. Acta Paul Enferm. 2007;20(3):30510.

Penteado RZ, Pereira, IMTB. Qualidade de vida e saúde vocal de professores. Rer. Saúde Pública v.41 n.2 São Paulo. Abr 2007.

Pichon-Rivière E.O processo grupal. São Paulo: Martins Fontes; 1991.

Pinheiro FA, Tróccoli BT, Carvalho CV. Validação do Questionário Nórdico de Sintomas Osteomusculares como medida de Morbidade. Rev Saúde Pública. 2002; 36(3):307-312. 
Poole K, Mason H. Disability in the upper extremity and quality of life in hand-arm vibration syndrome. Disabil Rehabil. 2005;27(22):1373-80.

Przysiezny WL. Distúrbios osteomusculares relacionados ao trabalho: um enfoque ergonômico. Ensaios de Ergonomia. Rev Virtual Ergon [Internet]. 2000 [citado 2010 maio 2]. Disponível em: www.eps.ufsc.br/ergon/revista/artigos /disturbios.pdf

Raffone AM, Hennington EA. Avaliação da capacidade funcional dos trabalhadores de enfermagem. Rev Saúde Pública. 2005; 39(4):669-676.

Salim C. Doenças do trabalho: exclusão, segregação e relações de gênero. São Paulo Perspec. 2003;17(1):11-24.

Sancinetti TR. Absenteísmo por doença na equipe de enfermagem [dissertação]. São Paulo: Escola de Enfermagem, Universidade de São Paulo; 2009.

Sancinetti TR, Gaidzinski RR, Felli VE, Fugulin FMT, Baptist PCP, Ciampone MHT, et al . Absenteísmo - doença na equipe de enfermagem: relação com a taxa de ocupação. Rev Esc Enferm USP. 2009;43(n.esp.2):1277-83.

Santos AV, Mendes AM, Araujo LKR. Experiência em clínica do trabalho com bancários adoecidos por Ler/ Dort. Psicol Ciênc Prof. 2009;29(3):614-25.

Sápia T, Felli VEA, Ciampone MHT. Problemas de saúde de trabalhadores de enfermagem em ambulatórios pela exposição a cargas fisiológicas. Acta Paul Enferm. 2009;22(6):808-13.

Sato L. A representação social do trabalho penoso. In: Spink MJP, organizador. O conhecimento no cotidiano: as representações sociais na perspectiva da psicologia social. São Paulo: Brasiliense; 1993. p.188-211. 
Sauni R, Virtema P, Paakkonen R, Toppila E, Pyykkö I, Uitti J. Quality of life (EQ5D) and hand-arm vibration syndrome. Int Arch Occup Environ Health. 2010;83(2):209-16.

Settimi MM, Toledo LF, Paparelli G, Santana Filho WR, Silva JA, Costa RO, et al. Lesões por esforços repetitivos/distúrbios osteomusculares relacionados ao trabalho: abordagem interdisciplinar. Rev Rede Esp. 1998;(ed. esp.):149-53.

Schmidt DRC, Dantas RAS. Qualidade de vida no trabalho de profissionais de enfermagem, atuantes em unidades do bloco cirúrgico, sob a ótica da satisfação. Rev Latino Am Enferm. 2006;14(1):54-60.

Schmidt DRC, Dantas RAS, Marziale MHP. Qualidade de vida no trabalho: avaliação da produção científica na enfermagem brasileira. Acta Paul Enferm. 2008; 21(2):330-7.

Silva FJ. A capacidade para o trabalho e a fadiga entre trabalhadores de enfermagem [dissertação]. São Paulo: Escola de Enfermagem, Universidade de São Paulo; 2011.

Sjostrom R, Alricsson M, Asplund R. Back to work: evaluation of a multidisciplinary rehabilitation programme with emphasis on musculoskeletal disorders; a two-year follow up. Disabil Rehabil. 2008;30(9):649-55.

Sluiter JK, Frings-Dresen MHW. Quality of life and illness perception in working and sick-listed chronic RSI patients. Int Arch Occup Environ Health. 2008;81(4):495-501. 
Talhaferro B, Barboza DB, Domingos NAM. Qualidade de vida da equipe de Enfermagem da Central de materiais e esterilização. Rev Ciênc Med (Campinas). 2006;15(6):495-506.

Tinubu BMS, Mbada CE, Oyeyeme AL, Fabunmi AA. Work-related musculoskeletal disorders among nurses in Ibadan: a cross-sectional survey. BMC Musculoskelet Disord [Internet]. 2010 [cited 2010 Oct 16];11:12. Available from: ttp://www.biomedcentral.com/1471-2474/11/12.

United States Department of Labor. Annual statistics [Internet]. Chicago; 2009 [cited 2010 Oct 13]. Available from: http://www.dol.gov

Vido MB, Fernandes RAQ. Qualidade de vida: considerações sobre conceito e instrumentos de medida. Online Braz J Nurs 2007; 6(2). Disponível em:http://www.uff.br/objnursing/index.php/nursing/article/view/j.16764285.2007.87 0/197 . 21 Sept 2007

Yeng LT, Teixeira MJ, Fernandes MM, Zakka TRM, Loduca A. Distúrbios osteomusculares relacionados ao trabalho. Rev Med. 2001;80(2):422-42.

World Health Organization (WHO). The WHOQOL Group. The World Health Organization Quality of Life Assessment (WHOQOL): position paper from the World Health Organization. Soc Sci Med. 1995;41(10):1403-9.

World Health Organization (WHO). The Ottawa charter for health promotion. Geneva: WHO; 1986.

Wunsch Filho V. Perfil epidemiológico dos trabalhadores. Rev Bras Med Trabalho. 2004;2(2):103-17. 


\section{APÊNDICE 1}

\section{PARTE 1}

Questionário sociodemográfico

Data:

Nome:

Data de nascimento:

Peso:

Estado civil:

Filhos:

Meio

(1):

Meio

de

transporte

utilizado

(2):

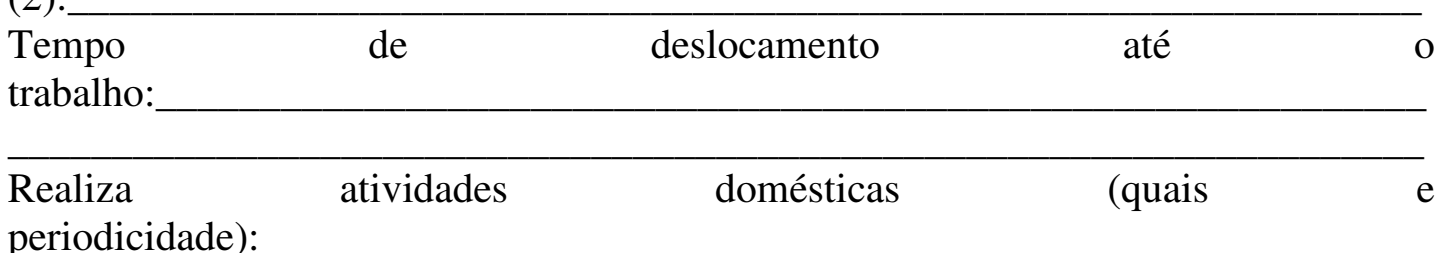

periodicidade):

Profissão:

Local

de

trabalho

(1):

Local

de

trabalho

(2):

Quanto

tempo

na

função:

Histórico

profissional:

Tarefas

predominantes

de

trabalho:

Restrição

trabalho:

Diagnóstico:

Histórico

patologia: 
Sintomas

atuais:

Tratamentos

realizados:

Outras

patologias:

Uso de medicamentos:

Atividades

de

lazer cotidianas:

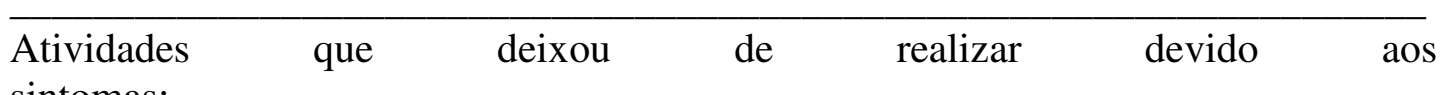
sintomas:

\begin{tabular}{llllll}
\hline $\begin{array}{l}\text { Modificações } \\
\text { sintomas: }\end{array}$ & no & seu & cotidiano & devido & aos \\
\hline
\end{tabular}

PARTE 2

Questões norteadoras

"Fale-me sobre sua qualidade de vida."

"Como seus sintomas interferem na sua qualidade de vida?"

“Como você lida com sua dor?”

"Fale-me sobre seu lazer."

"Conte-me sobre como você tenta cuidar suas posturas no trabalho."

“O que a participação neste grupo te proporcionou?" 


\section{APÊEDICE 2}

CONVITE PARA PARTICIPAÇÃO NOS GRUPOS DA PESQUISA (expostos em todos os setores da Instituição em questão)

Grupo de Terapia Ocupacional para portadores de DORT em ombro, cotovelo e mão

Se você possui DORT nos membros superiores há mais de 6 semanas, nunca fez tratamento de Terapia Ocupacional, é enfermeiro, auxiliar ou técnico de enfermagem e busca melhorar a sua qualidade de vida, venha fazer um grupo de Terapia Ocupacional (duração de 7 semanas, 1 vez/semana - datas em anexo)

$\mathrm{Na}$ folha em anexo, favor colocar seu nome e telefone (manifestar interesse no GRUPO 1 ou GRUPO 2). Obrigada! 
GRUPO 1

HORÁRIO: $14: 15$ às 16:00

DATAS: 01/11, 08/11, 22/11, 29/11, 06/12, 13/12

\begin{tabular}{|l|l|}
\hline Nome & Telefone ou e-mail \\
\hline & \\
\hline & \\
\hline & \\
\hline & \\
\hline & \\
\hline & \\
\hline & \\
\hline & \\
\hline & \\
\hline
\end{tabular}

(pg.2)

GRUPO 2

HORÁRIO: 14:15 às 16:00

DATAS: 09/11, 16/11, 23/11, 30/11, 07/12 e 14/12

\begin{tabular}{|c|c|}
\hline Nome & Telefone ou e-mail \\
\hline & \\
\hline & \\
\hline & \\
\hline & \\
\hline & \\
\hline & \\
\hline & \\
\hline & \\
\hline & \\
\hline & \\
\hline
\end{tabular}

(pg.3) 


\section{APÊNDICE 3}

\section{TERMO DE CONSENTIMENTO LIVRE E ESCLARECIDO}

\section{Dados de identificação}

Título do Projeto: Qualidade de vida de trabalhadores de Enfermagem com Distúrbios Osteomusculares Relacionados ao Trabalho

Pesquisador Responsável: Ana Paula Pelegrini Ratier Telefones para contato: 11 30919302

Instituição a que pertence o Pesquisador Responsável: Hospital Universitário Universidade de São Paulo

Endereço: Av. Prof. Lineu Prestes, 2565 - Cidade Universitária - CEP: 05508-000 São Paulo - SP - Telefone: 3091-9457 - Fax: 3091-9452 - E-mail: cep@hu.usp.br.

Nome do voluntário:

Idade: anos R.G.

Sexo: Data de nascimento:

Endereço:

Telefone:

O senhor(a) está sendo convidado(a) a participar do projeto de pesquisa "Qualidade de vida de trabalhadores de Enfermagem com Distúrbios Osteomusculares Relacionados ao Trabalho" de responsabilidade da pesquisadora Ana Paula Pelegrini Ratier sob a orientação da $\operatorname{Prof}^{a}$ Dr $^{a}$ Vanda Andres Felli.

Este trabalho pretende entender se a doença que o senhor(a) possui interfere ou atrapalha na qualidade de vida do senhor(a), de que maneira seus sintomas interferem e através do direcionamento e do conhecimento de uma terapeuta ocupacional, construir propostas para ajudar na melhora de sua qualidade de vida, do seu cotidiano e da forma como enfrenta sua condição.

O estudo com o(a) senhor(a) acontecerá no setor de Terapia Ocupacional do HU-USP e será feito em grupo, onde haverá 1 atendimento por semana durante 5 semanas. No grupo, serão mencionadas orientações diversas que tem como objetivo diminuir a sua dor ou seu formigamento, ensinar movimentos e posturas adequadas, verificar como realizar melhor algumas atividades, refletir sobre alternativas para melhorar a qualidade de vida, sugerir atividades de lazer, dentre outras.

Haverá um encontro inicial individual, onde o senhor(a) responderá uma entrevista com seus dados pessoais, de trabalho e de seus sintomas.

Em todos os encontros haverão entrevistas gravadas onde o senhor(a) responderá perguntas sobre sua doença e sua qualidade de vida e onde discutiremos, proporemos e vivenciaremos situações, técnicas, exercícios para ajudar na melhora 
da sua qualidade de vida. Ao final das 5 semanas, serão repetidas algumas perguntas para sabermos se o que foi aprendido no grupo ajudou a melhorar em algo ou para saber se a experiência que o(a) senhor(a) viveu modificou alguma opinião ou pensamento.

Todos os dados que o(a) senhor(a) disser são confidenciais e privados do pesquisador do trabalho, não sendo repassados para nenhuma outra fonte/pessoa/veículo de comunicação.

O senhor(a) terá toda a liberdade durante e após o estudo de tirar dúvidas ou perguntar sobre as técnicas ensinadas e usadas.

A sua participação é voluntária e em qualquer momento este consentimento poderá ser retirado e seu tratamento continuará normalmente.

Declaro que, após convenientemente esclarecido pelo pesquisador e ter entendido o que me foi explicado, consinto em participar do presente Projeto de Pesquisa

São Paulo, de de

Nome do participante (voluntário)

Nome do pesquisador

Hospital Universitário - Universidade de São Paulo 


\section{ANEXO 1}
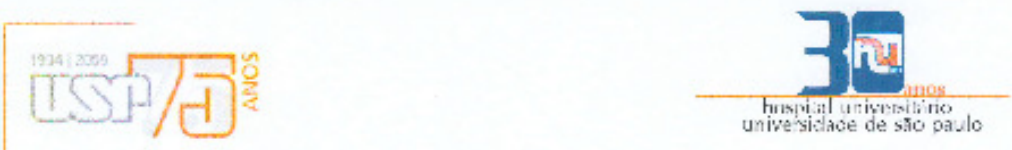

São Paulo, 6 de agoswo de 2011.

ITw: S S S

Ana Paufa Petegrini Ratier

Serviço de Terapia Ocupacional - Departamentu Médico

Hospital [?n'rosstário

L. VIVFIRSIISAIDH:IJES SAOOPAUI.O

REFERLNIE: Projeto de Pesquisa "Couberendo e implemerilemito a qualidade de sida de Irebalhadires de cr.fermigem tern dis.úrbios ostcomusculares relacionadus as trasalho" - Pesquisador(a) responsável: Ans Paula Pelcyrini Rzticr - Co-Autor(es): Irofa. Dra. Vanda Flixia Andrcs Felli - Registro CEP-HU/LSP: 1128:11 SISNEP' CAAL: 10041.0.146.148-'1.

Presato(a) Senhor(a)

O Corritê de Ética em P’esquisa do Jlospital L nirersitário da L niversidade de Sào Paulo, en reuniäo ordizária real:zada no dia 5 de agosto de 2011 , analisou o Projezo de Pesquisa acine citado, considerando-o cono APROYADO, bem como o scu Termo de Consentimento Livre e Esclarecido.

1.embramos que cahe an pesquisacor elahorar e apresentar a este Comitè: rolatórios anuais (parciais ou fỉnal, cm funçăo da du.raçăo da pesquisę), de acordo com a Resoluç2̃o ñ 196996 do Consclho Nacional de Saúde, inciso IX.2, letra "c".

O primeiro relatório est́́ previsto para 5 de agosto de 2012.

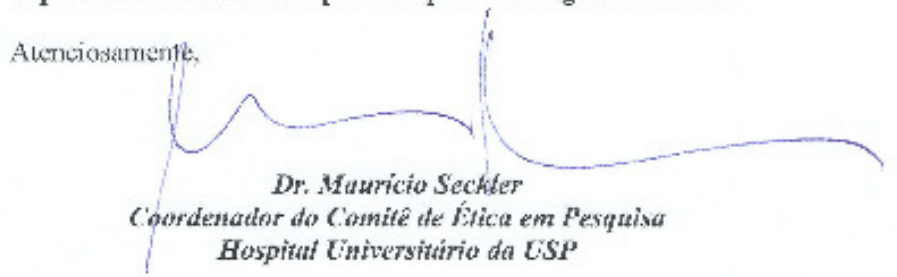

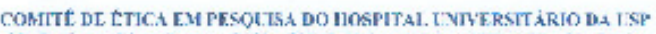

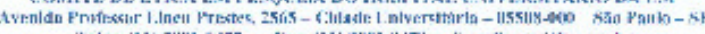

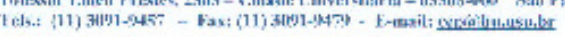

